\title{
Platinum Group Metals: A Review of Resources, Production and Usage with a Focus on Catalysts
}

\author{
Anthony E. Hughes ${ }^{1,2, *(\mathbb{D})}$, Nawshad Haque ${ }^{3 \oplus}$, Stephen A. Northey ${ }^{4}\left(\mathbb{D}\right.$ and Sarbjit Giddey ${ }^{3}$ \\ 1 CSIRO Mineral Resources, Gate 5, Normanby Rd, Clayton, VIC 3168, Australia \\ 2 Institute for Frontier Materials, Deakin University, 75 Pigdons Rd, Waurn Ponds, \\ Geelong, VIC 3216, Australia \\ 3 CSIRO Energy, Gate 5, Normanby Rd, Clayton, VIC 3168, Australia; nawshad.haque@csiro.au (N.H.); \\ sarb.giddey@csiro.au (S.G.) \\ 4 Institute for Sustainable Futures, University of Technology Sydney, Building 10, 235 Jones St, \\ Ultimo, NSW 2007, Australia; stephen.northey@uts.edu.au \\ * Correspondence: tony.hughes@csiro.au; Tel.: +61-3-9545-2705
}

Citation: Hughes, A.E.; Haque, N. Northey, S.A.; Giddey, S. Platinum Group Metals: A Review of Resources, Production and Usage with a Focus on Catalysts. Resources 2021, 10, 93. https://doi.org/ $10.3390 /$ resources10090093

Academic Editor: Mario Schmidt

Received: 18 August 2021

Accepted: 13 September 2021

Published: 20 September 2021

Publisher's Note: MDPI stays neutral with regard to jurisdictional claims in published maps and institutional affiliations.

Copyright: (c) 2021 by the authors. Licensee MDPI, Basel, Switzerland. This article is an open access article distributed under the terms and conditions of the Creative Commons Attribution (CC BY) license (https:// creativecommons.org/licenses/by/ $4.0 /)$.

\begin{abstract}
The major applications of PGMs are as catalysts in automotive industry, petroleum refining, environmental (gas remediation), industrial chemical production (e.g., ammonia production, fine chemicals), electronics, and medical fields. As the next generation energy technologies for hydrogen production, such as electrolysers and fuel cells for stationary and transport applications, become mature, the demand for PGMs is expected to further increase. Reserves and annual production of $\mathrm{Ru}$, $\mathrm{Rh}, \mathrm{Pd}, \mathrm{Ir}$, and Pt have been determined and reported. Based on currently available resources, there is around 200 years lifetime based on current demand for all PGMs, apart from Pd, which may be closer to 100 years. Annual primary production of $190 \mathrm{t} / \mathrm{a}$ for Pt and $217 \mathrm{t} / \mathrm{a}$ for Pd, in combination with recycling of $65.4 \mathrm{t} / \mathrm{a}$ for $\mathrm{Pt}$ and $97.2 \mathrm{t} / \mathrm{a}$ for $\mathrm{Pd}$, satisfies current demand. By far, the largest demand for PGMs is for all forms of catalysis, with the largest demand in auto catalysis. In fact, the biggest driver of demand and price for $\mathrm{Pt}, \mathrm{Pd}$, and $\mathrm{Rh}$, in particular, is auto emission regulation, which has driven auto-catalyst design. Recovery of PGMs through recycling is generally good, but some catalytic processes, particularly auto-catalysis, result in significant dissipation. In the US, about 70\% of the recycling stream from the end-of-life vehicles is a significant source of global secondary PGMs recovered from spent auto-catalyst. The significant use of PGMs in the large global auto industry is likely to continue, but the long-term transition towards electric vehicles will alter demand profiles.
\end{abstract}

Keywords: platinum group metal (PGM); catalysts; life cycle assessment; recycling; mineral resources; autocatalysis; fuel cells

\section{Introduction}

The platinum group of metals (PGM) include six d-block metals from groups 8, 9, and 10 as well as periods 5 and 6 . The metals are ruthenium ( $R u)$, rhodium (Rh), palladium (Pd), osmium (Os), iridium ( $\mathrm{Ir}$ ), and platinum (Pt). The chemistry of these elements is similar and is based on $4 \mathrm{~d}$ electron shells $(\mathrm{Ru}, \mathrm{Rh}$, and $\mathrm{Pd}$ ) or $5 \mathrm{~d}$ shells (Os, $\mathrm{Ir}$, and $\mathrm{Pt}$ ). The division of the PGMs into light PGMs ( Ru, Rh, Pd) and heavy PGMs (Os, Ir, and Pt), reflecting their atomic numbers (or weights) [1], is sometimes used.

PGMs are vitally important for a range of end-use applications in consumer and commercial products, as well as industrial processes. The varied applications of PGMs are of considerable importance in the modern era, so an understanding of ongoing PGM demand and its end-uses is critical for managing PGM reserves. Most notably, PGMs find widespread usage in a variety of catalytic processes, such as the production of ammonia and ammonium nitrate, as well as catalytic converters to reduce hazardous and polluting emissions from vehicle exhaust systems. 
A major objective of this article is to provide a short overview of current use of PGMs in catalysis and, in particular, catalysts in the auto market as well as projected use in the near future with the introduction of electric vehicles (EVs). The auto market is the largest single end-user of PGMs and may end up one of the biggest dissipaters. For completeness, and preceding the detailed review of PGMs in the auto area, this review covers the known stocks of PGMs in mineral resources, the supply of PGMs from primary mineral resources and secondary sources, and a comprehensive overview of the uses of PGMs in the industrial sector, which is the second largest area of demand for Pt, which leads into PGM use in industrial catalytic processes. This is followed by a major section on autocatalysis for both internal combustion engine vehicles (ICEVs) and EVs, including projections for PGM used based on IEA projections for EV uptake. This is followed by an examination of the potential substitutability of PGMs in these processes, which highlights some of the fundamental scientific reasons why substitution may be difficult. Finally, there is some examination of the dissipation of PGMs. In doing so, the reader is provided with a broad ranging overview of the use of PGMs by sector and its inter-relationships with other uses in the modern world.

\section{Geologic Abundance, Ore Bodies, Mineralogy and Resources}

PGMs are among the rarest elements in the periodic table, as can be inferred from Table 1. Common elements, such as copper $(\mathrm{Cu})$ and iron $(\mathrm{Fe})$, are included to compare the relative abundance of elements that are used extensively in the modern world including in catalytic processes. Cerium (Ce) is included since it is an important support in auto catalysts; an area which also has the largest worldwide consumption of $\mathrm{Pt}$ and $\mathrm{Pd}$.

It can be seen that $\mathrm{Pt}$ and $\mathrm{Pd}$, with crustal abundances of 1.625 and 0.675 atoms $/ 10^{6} \mathrm{Si}$ atoms, respectively, are the most abundant of the PGMs, with $\mathrm{Rh}$ as the rarest at $0.214 / 10^{6} \mathrm{Si}$ atoms which is a little over a tenth of the $\mathrm{Pt}$ abundance [2]. In addition to abundance, world resources are included in Table 1 (described in more detail in Section 3). The resources of PGMs appear small when compared to those of $\mathrm{Cu}, \mathrm{Fe}$, and $\mathrm{Ce}$, but consumption is also small, so known resources for $\mathrm{Pt}$, at least, are sufficient to meet needs for at least 200 years, based on data published by the USGS [3].

To understand supply, it is important to identify the types of ore bodies from which PGMs are sourced, particularly whether they are primary products, coproducts, or byproducts since this will influence their supply. PGMs occur mostly in either a siderophilic (iron-loving) state, where they occur as pure metals, or metal alloys or a chalcophyllic (sulfide) state in ores. The richest ore bodies containing PGM are the ultramafic and mafic igneous rocks which occur in Canada, Russia, South Africa, United States, and Zimbabwe. The PGM content for the individual metals for a number of these ore bodies is provided in $\mathrm{g} / \mathrm{t}$ in Table 2. The level of extraction depends on the PGM concentration in the ore body and the price of the individual PGMs. In some ore bodies, the primary production may be for other metals, whereas in other ore bodies, PGMs may be the primary product. For example, in Canada, PGMs are a by-product of copper-nickel production in the Sudbury complex, Ontario. This complex is thought to be the result of meteoritic impact which resulted in the PGM enrichment [4]. Russian PGMs are co-products of copper-nickel mining, with the majority coming from north-western Siberia (Noril'sk), as well as some alluvial sources [5]. Nassar looks, in more detail, at issues surrounding co-production [6]. The Noril'sk complex arose from sub volcanic sills and is the major source of PGMs with only minor production from placer deposits $[4,7,8]$. In South Africa, the PGMs are the primary product mined from the Merensky reef, UG2 reef, and Platreef (Table 2), which are all part of the Bushveld complex [7,8]. The main source of minerals for PGMs are chromite and sulphide ores [9]. The Zimbabwe regions include Mimosa, Ngezi, and Unki, which produce pristine sulphide ores [10]. Both the South African and Zimbabwean are mafic to ultramafic layered intrusions. The only source of PGMs in the US is at the Stillwater complex in Montana, where they are produced as a co-products [7]. 
Table 1. Abundance with respect to every million Si atoms [2], crustal abundance, and world resources.

\begin{tabular}{|c|c|c|c|c|}
\hline Metal & $\begin{array}{l}\text { Atomic } \\
\text { Number }\end{array}$ & $\begin{array}{c}\text { Abundance } \\
\text { (Atoms } / 10^{6} \text { Si Atoms) }\end{array}$ & $\begin{array}{c}\text { Abundance in Upper } \\
\text { Continental Crust (ppb) }\end{array}$ & $\begin{array}{l}\text { World Resources } \\
\text { (Metric Tonnes) }\end{array}$ \\
\hline Copper $(\mathrm{Cu})$ & 29 & 212 & $\approx 60,000$ & $3,034,700,000^{c}$ \\
\hline Iron $(\mathrm{Fe})$ & 28 & $600,000^{d}$ & $5.2 \mathrm{wt} \%$ & $110,000,000,000$ \\
\hline Ruthenium (Ru) & 44 & 1.49 & 0.03 & $4,459^{\mathrm{e}}, 5,000^{\mathrm{f}}$ \\
\hline Rhodium (Rh) & 45 & 0.214 & 0.018 & $3090^{\mathrm{e}}$ \\
\hline Palladium (Pd) & 46 & 0.675 & 0.526 & $24,302^{\mathrm{e}}$ \\
\hline Osmium (Os) & 76 & 1.00 & 0.05 & $580^{e}$ \\
\hline Iridium (Ir) & 77 & 0.821 & 0.022 & $1074^{\mathrm{e}}$ \\
\hline Platinum (Pt) & 78 & 1.625 & 0.599 & $32,986^{\mathrm{e}}$ \\
\hline Cerium $(\mathrm{Ce})$ & 58 & 2.26 & $65^{\mathrm{h}}$ & $299,000,000 \mathrm{~g}$ \\
\hline
\end{tabular}

${ }^{a}$ Note that this type of data may be expressed in weight percent where the PGMs are two orders lower than other rare elements such as some of the rare earths. ${ }^{b}[7]^{\mathrm{c}}[8]^{\mathrm{d}}$ [11] ${ }^{\mathrm{e}}$ From Table 2, method of calculation is described below. ${ }^{\mathrm{f}}[12],{ }^{\mathrm{g}}[13],{ }^{\mathrm{h}}$ Data are the average of values obtained from Wikipedia: abundance of elements in Earth's crust, http://en.wikipedia.org/wiki/Abundance_of_elements_in_

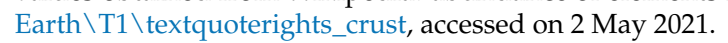

Table 2. PGM content in grams/tonne for various ore bodies along with PGM reserves by country and total reserves for the individual PGMs [3,8,14]. (H) indicates Hagelüken [14] and (M) indicates Mudd et al. [8] data.

\begin{tabular}{|c|c|c|c|c|c|c|c|c|}
\hline Ore Body & $\begin{array}{l}\mathrm{Pt} \\
\mathrm{g} / \mathrm{t}\end{array}$ & $\begin{array}{l}P d \\
g / t\end{array}$ & $\begin{array}{l}\mathrm{Rh} \\
\mathrm{g} / \mathrm{t}\end{array}$ & $\begin{array}{l}\mathrm{Ru} \\
\mathrm{g} / \mathrm{t}\end{array}$ & $\begin{array}{l}\mathrm{Ir} \\
\mathrm{g} / \mathrm{t}\end{array}$ & $\begin{array}{l}\text { Os } \\
\mathrm{g} / \mathrm{t}\end{array}$ & $\begin{array}{c}\text { Total PGM } \\
\text { g/t }\end{array}$ & $\begin{array}{c}\text { PGM Reserves } \\
\text { Tonnes }^{\text {a }}\end{array}$ \\
\hline \multicolumn{8}{|c|}{ South Africa } & 63,000 \\
\hline Merensky Reef (H) & 2.7 & 1.4 & 0.16 & 0.33 & 0.05 & 0.04 & 4.68 & \\
\hline - East Bushveld (M) & 2.32 & 1.22 & 0.13 & 0.23 & 0.04 & - & & \\
\hline - West Bushveld (M) & 3.6 & 1.6 & 0.28 & 0.63 & 0.14 & - & & \\
\hline Platreef $(\mathrm{H})$ & 1.9 & 1.9 & 0.12 & 0.14 & 0.04 & 0.03 & 4.13 & \\
\hline - North Bushveld (M) & 0.82 & 1.1 & 0.08 & - & - & - & 2.0 & \\
\hline UG2 (H) & 2.0 & 1.3 & 0.34 & 0.45 & 0.13 & 0.05 & 4.27 & \\
\hline - East Bushveld (M) & 2.42 & 2.06 & 0.45 & 0.76 & 0.18 & - & & \\
\hline - West Bushveld (M) & 2.89 & 1.48 & 0.54 & 0.93 & 0.22 & - & & \\
\hline \multicolumn{8}{|c|}{ Zimbabwe } & 1200 \\
\hline Hartely Complex & 2.6 & 1.8 & 0.21 & - & - & - & 4.61 & \\
\hline \multicolumn{8}{|c|}{ USA } & 900 \\
\hline Stillwater Complex & 3.3 & 11 & 0.6 & 0.36 & 0.21 & - & 15.47 & \\
\hline \multicolumn{8}{|c|}{ Canada } & 310 \\
\hline Sudbury Complex & 0.3 & 0.4 & 0.03 & 0.04 & 0.01 & 0.01 & 0.79 & \\
\hline Lac-des lles & 0.2 & 2.3 & - & - & - & - & 2.5 & \\
\hline \multicolumn{8}{|c|}{ Russia } & 3900 \\
\hline Noril'sk & 2.5 & 7 & 0.24 & - & - & - & 9.74 & \\
\hline Reserve (tonnes) & 32,374 & 24,433 & 3909 & 6731 & 1530 & 333 & - & 69,310 \\
\hline Lifetime (years) $^{b}$ & 202 & 116 & 166 & 201 & 224 & - & - & - \\
\hline
\end{tabular}

a [3]. It should also be noted that reporting of total PGMs may include Au that is also found in many PGM deposits. Such reporting is usually designated with "nE" with n varying with the number of elements that are reported but always including Au. Thus $3 \mathrm{E}$ is Pt, Pd, and $\mathrm{Au}, 4 \mathrm{E}$ is $\mathrm{Pt}, \mathrm{Pd}, \mathrm{Ru}$, and $\mathrm{Au}$, etc. The reserves reported here do not include any contribution from Au. ${ }^{\mathrm{b}}$ Figures are determined from the calculated reserves in tonnes, divided by Johnson-Matthey figures for productions for Pt and Pd and Johnson-Matthey 2019 figures for demand for $\mathrm{Rh}, \mathrm{Ru}$, and Ir. These figures do not include material sourced from recycling. Note that variation between 2018 and 2019 are small with primary supply of Pt in 2018 being $6110 \mathrm{oz}$ and, in 2019, $6033 \mathrm{oz}$ while Pd in 2018 was $7006 \mathrm{Oz}$ and, in 2019, $7069 \mathrm{oz}$.

While figures for world reserves of Pt and Pd are often reported, those of the other PGMs are not commonly reported in the open access literature. Accordingly, the authors 
make some basic estimates for reserves for a simple assessment of their lifetime (Table 2). The calculation of estimates for these reserves is based on individual ore body composition and is described in the Appendix A. Note also that common definitions are used, where resource means that the mineral has a concentration that is currently, or could potentially be, economically extracted, whereas reserve is that part of the resource that has been shown to meet the specified minimum value for current mining and production under prevailing market conditions. It can be seen that $\mathrm{Pt}$ and $\mathrm{Pd}$ have the largest reserves, followed by $\mathrm{Rh}$ and $\mathrm{Ru}$, which are nearly an order of magnitude lower. The lowest are Ir and Os.

An estimate of the reserve lifetime for each element assuming 2019 figures for production (Pt, Pd) or demand ( $\mathrm{Rh}, \mathrm{Ru}$, and $\mathrm{Ir}$ ) is also shown in Table 2. As estimates of reserves and resources are dynamic and vary over time, due to ongoing mineral exploration and changing market conditions, static reserve lifetimes are often a misleading metric for understanding long-term reserve and resource depletion [6,8]. For example, Mudd et al. [8] reported that the total reserves and resources for PGMs have increased over the period of 2009 to 2015 . Another contribution to uncertainty for lifetime data is that the ore breakdown in Table 2 may miss other ore bodies and mines with completely different PGM content, meaning that the ore contents (averaged or individual) may not be representative values for all ore reserves for individual countries. As a counterpoint, the ore bodies listed in the table constitute over $90 \%$ of global production, and the ore content is relatively well known. By way of cross-correlation of the calculations presented here, a figure of 5,000 tonnes is reported for $\mathrm{Ru}[12,15]$, which is in good agreement with the 6731 tonnes determined using the procedure described in the Appendix A. Despite these uncertainties, the lifetimes presented in Table 2 clearly demonstrate that there are no immediate PGM supply concerns due to geological resource depletion, although geopolitical and market factors can create short-term supply risks [15-18]. All the PGMs, apart from $\mathrm{Pd}$, have lifetimes in the vicinity of 200 years. The increase in Pd demand for auto-catalyst applications has halved the expected lifetime in recent years, but as with the other PGMs, there is no immediate threat. A shift to EVs will influence PGM demand, but electrode catalysts will still generate a significant demand for PGMs, which may represent a supply risk, as outlined by Kiemel et al., for Germany [19].

\section{Supply}

With respect to mining, the extraction of PGMs from their parent ores is a multistep process and varies according to the host mineralogy (sulphides or silicates). PGM extraction is complex and dealt in detail by previous authors [20,21]. However, a brief summary of extraction from the South African ores is provided since they dominate world supply. Minerals associated with the PGMs in the Merensky reef (Bushveld complex) include Pt-Fe alloys such as $\mathrm{Pt}_{3} \mathrm{Fe}$, sulphides such as braggite $(\mathrm{PtS})$, cooperite $((\mathrm{Pt}, \mathrm{Pd}, \mathrm{Ni}) \mathrm{S})$, moncheite $\left((\mathrm{PtPdNi})(\mathrm{TeBiSb})_{2}\right)$ and laurite $\left((\mathrm{Ru}, \mathrm{Fe}, \mathrm{Os}, \mathrm{Ir}, \mathrm{Pt}) \mathrm{S}_{2}\right)$, and the alloy, kotulskite $((\mathrm{Pt}, \mathrm{Pd}$, $\left.\mathrm{Ni})(\mathrm{Te}, \mathrm{Bi}, \mathrm{Sb})_{2}\right)[22,23]$, as well as gold as electrum $\left(\mathrm{Au}_{\mathrm{x}} \mathrm{Ag}_{\mathrm{y}}\right)$. The first step is physical separation, usually via floatation, to produce a mineral concentrate, with typical recoveries of 60 to $90 \%$ of the sulphide for these South African ores depending on the degree of oxidation, with the PGM content ranging from 100 to $1000 \mathrm{~g} / \mathrm{t}$ [24]. After drying, this is followed by a pyrometallurgical separation at $1450{ }^{\circ} \mathrm{C}$ to $1500{ }^{\circ} \mathrm{C}$, resulting in a Cu-NiFe-S matte. In the next stage, most producers use leaching processes in sulfuric acid in autoclaves under pressure, temperature, and with excess oxygen to sequentially leach $\mathrm{Ni}$, $\mathrm{Cu}, \mathrm{Fe}$, and then Se, As, and Te to make a final concentrate for precious metal refining to extract the individual PGMs. The final stage is based on selective extraction using either ion exchange processes, electrolytic processes, or solvents. These steps can be replaced by extraction of individual components in an immiscible organic solvent [24].

PGM supply has two sources, including primary production (from mining, including stockpiles) and secondary production, which includes sourcing from recycling (see Section 5). Annual world supply (Table 3) of PGMs in 2018 and 2019 was in the vicinity of 450 t/a 
(figures vary: 450-470 t/a (2018-2019) including 430 t/a supply for Pt, Pd, and $\mathrm{Rh}$ as well as $\sim 30 \mathrm{t} / \mathrm{a}$ Ir and Ru (sourced from demand figures Johnson-Matthey [25]).

Table 3. Total PGM supply (tonnes/annum) by element and by country in 2018 (2019).

\begin{tabular}{ccccccc}
\hline Element & $\mathbf{R u}^{\mathbf{b}}$ & $\mathbf{R h}^{\mathbf{a}}$ & $\mathbf{P d}^{\mathbf{a}}$ & $\mathbf{O s}^{\mathbf{b}}$ & $\mathbf{I r}^{\mathbf{b}}$ & $\mathbf{P t}^{\mathbf{a}}$ \\
\hline South Africa & 29.6 & $19.2(19.4)$ & $79.1(81.7)$ & 1.5 & 6.7 & $\begin{array}{c}138.9 \\
(136.8)\end{array}$ \\
\hline Russia & - & $2.2(2.1)$ & $92.6(92.9)$ & & & $21.4(22.4)$ \\
\hline Nth America ${ }^{c}$ & 0.67 & $0.7(0.6)$ & $29.8(29.7)$ & 0.17 & 0.17 & $10.3(10.1)$ \\
\hline Zimbabwe & - & $1.3(1.2)$ & $12.2(11.8)$ & - & - & $14.7(14.0)$ \\
\hline Other & - & $0.2(0.2)$ & $4.2(3.8)$ & - & - & $4.7(4.3)$ \\
\hline Total & - & $23.6(23.5)$ & $\begin{array}{c}217.9 \\
(219.9)\end{array}$ & - & - & 190.0 \\
& & & & & $(187.6)$ \\
\hline
\end{tabular}

a Pt, Pd, and Rh supply data from Johnson-Matthey 2019 (JM2020) market report data, which has complete data for the previous year. ${ }^{b}$ Data calculated from ore contents in the same way as the reserve totals-by using annual PGM production data [3]. ${ }^{\mathrm{c}} \mathrm{Ru}, \mathrm{Os}$, Ir from Canadian Ores.

Annual world supply by country for $\mathrm{Pt}, \mathrm{Pd}$ and, $\mathrm{Rh}$ are provided in various reports $[3,7]$ but annual supply figures for the other PGMs are not freely available in open source literature. In the case of the Russian ores, Ru, Ir, or Os may be a few orders of magnitude lower than $\mathrm{Pd}$ and $\mathrm{Pt}$ [26], meaning that there may be refinement of $\mathrm{Ru}$, Ir, and Os.

\section{Usage and Demand}

While this section provides an overview of PGM usage and demand, it goes into detail where PGM are used in the catalytic process, particularly auto-catalysis, which has the highest overall demand for PGMs. First, a short section on non-catalytic applications of PGM is presented. This is followed by a more extensive section covering catalytic usage and demand for PGM-based catalysts. As can be seen in Table 3, Pt and Pd have the largest primary production and demand. Figure 1 shows the demand by market sectors for $\mathrm{Pt}$, $\mathrm{Pd}$, and Rh. The classification of sectors is derived from the Johnson-Matthey market reports [25]. Ru and Ir are exclusively used in the Industrial sector, so they are not included in Figure 1.

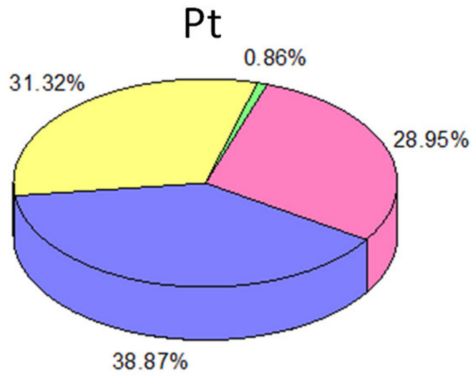

$\mathrm{Rh}$

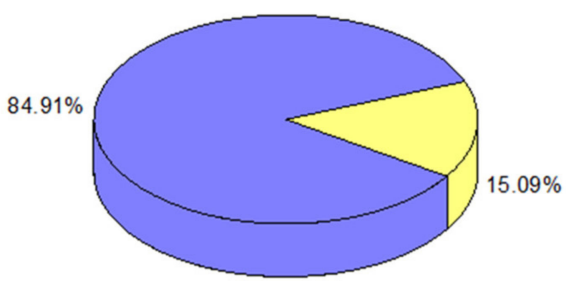

$\mathrm{Pd}$
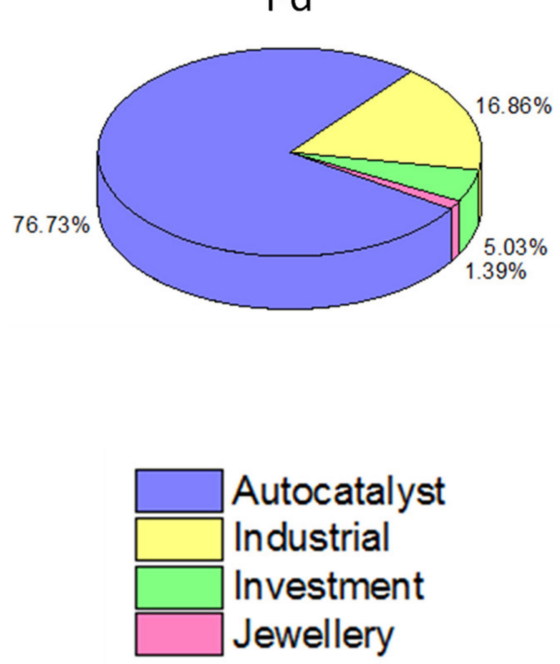

Figure 1. Breakdown of $\mathrm{Pt}, \mathrm{Pd}$, and Rh net demand, expressed as percent of total demand in 2019. Total net demand for Pt was 196.0 tonnes, for Pd was 249.4 tonnes and for Rh was 24.3 tonnes [27]. 


\subsection{Non-Catalytic Usage and Demand}

A summary of usage of PGMs in non-catalytic applications is presented in Table 4, which also provides information on alternatives for current applications where they exist. As Nassar points out, the application of PGM in any particular field may often represent the optimum, so the use of substitutes may mean a regression to earlier technologies [6].

Table 4. Non- Catalytic Applications for PGM and potential substitutes.

\begin{tabular}{|c|c|c|c|}
\hline Classification & Application & PGM & Substitution \\
\hline \multirow[t]{2}{*}{ Jewellery } & & $\begin{array}{l}\text { Pt, Ir, Pd Alloys 950, 750, } 590 \& \\
\text { white gold }[28,29]\end{array}$ & $\begin{array}{l}\text { Au (as a value substitute). White gold Ni, } \mathrm{Zn} \& \mathrm{Sn} \\
{[29,30] \text { as aesthetic substitutes. }}\end{array}$ \\
\hline & Bright Nickel & $\mathrm{Rh}$ & Rh strike for plating on soft soldered jewellery [31] \\
\hline \multirow[t]{2}{*}{ Glass } & Dies for fibreglass & Pt-Rh (up to $40 \%$ ) & $\begin{array}{c}\text { Zirconia/Pt [32]. The non-wettability of Pt is a key } \\
\text { property here, so there may be no real alternative. } \\
\text { Dilution of the PGM content possible. }\end{array}$ \\
\hline & Crucibles & $\begin{array}{c}\text { Pt-Rh (up to } 40 \% \text { ) } \\
\text { Ir (most demanding applications) }\end{array}$ & $\begin{array}{c}\text { Alumina, Zirconia [33], as with fiberglass } \\
\text { wettability may be an issue with oxide crucibles at } \\
\text { high temperature. Tin oxide crucibles [34] } \\
\text { These are used in single crystal manufacture } \\
\text { where the non-reactivity is a key property [35]. } \\
\text { There is probably no good substitute. }\end{array}$ \\
\hline \multirow[t]{11}{*}{$\begin{array}{l}\text { Electronics \& } \\
\text { Electrical }\end{array}$} & Hard Discs & CrCoPt alloy, Ru layer & $\begin{array}{c}\text { No direct replacement but alternative technologies, } \\
\text { e.g., solid state devices. } \\
\text { Dissipative }\end{array}$ \\
\hline & Filters & Ir [36] & $\begin{array}{l}\text { Li tantalate filters for mobile phones [37] } \\
\text { Dissipative }\end{array}$ \\
\hline & Capacitors & $\mathrm{Pd}$ & $\begin{array}{c}\text { Multilayer ceramic capacitors (MLCC) [38] } \\
\text { Sub: Ni as replacement [39] } \\
\text { Dissipative }\end{array}$ \\
\hline & Contacts & $\mathrm{Rh}, \mathrm{Ru}, \mathrm{Ir}$ & $\begin{array}{l}\text { Used for hardening contacts such as in reed } \\
\text { switches }[40,41] \\
\text { Sub: Reversion to older technology } \\
\text { Dissipative }\end{array}$ \\
\hline & Mobile Phones & $\mathrm{Pd}, \mathrm{Pt}$ & $\begin{array}{c}\text { Largely as MLCCs and connectors. } 0.009-0.015 \\
\mathrm{~g} / \text { phone, } 0.004 \mathrm{~g} / \text { phone [42] Combine } 2 \text { phone } \\
\text { types. } \\
\text { Dissipative }\end{array}$ \\
\hline & Conductive pastes & Pd-Ag & $\begin{array}{l}\text { Printable pastes used in circuitry [43]. Reversion to } \\
\text { older technologies based on Au. }\end{array}$ \\
\hline & Connectors & $\mathrm{Pd} / \mathrm{Ni}$ & $\begin{array}{c}\text { Connectors. Pd corrosion resistance and hardness } \\
\text { make them superior [29]. Return to hard gold. } \\
\text { Dissipative }\end{array}$ \\
\hline & $\begin{array}{l}\text { Hybrid integrated } \\
\text { circuits }\end{array}$ & Ag-Pd connecting tracks [35] & $\begin{array}{l}\text { These can be produced using conductive pastes. } \\
\text { Again, reversion to older technologies such as Au. }\end{array}$ \\
\hline & Resistors & $\mathrm{RuO}_{2}[44]$ & Ru thick film resistors \\
\hline & $\begin{array}{c}\text { Fuel Cells } \\
\text { (NB JM classification } \\
\text { has Fuel cells under } \\
\text { electric and } \\
\text { electrical) }\end{array}$ & $\begin{array}{l}\text { PEM fuel cell: Pt, Pt-transition } \\
\text { metal alloys [45] }\end{array}$ & $\begin{array}{c}\text { Catalyst dilution e.g., } \mathrm{Pt}_{3} \mathrm{Co}, \mathrm{Pt}_{3} \mathrm{Ni}[46] \\
\text { Sub: Fe-N-C catalyst [47], } \mathrm{Fe}(\mathrm{Co})-\mathrm{N}-\mathrm{C}[48,49]\end{array}$ \\
\hline & Electrolysers & $\begin{array}{l}\mathrm{Pt} \text {, Ir in proton exchange } \\
\text { Membranes }[19,50]\end{array}$ & $\begin{array}{l}\text { Pt used as cathode catalyst for hydrogen evolution } \\
\text { and Ir used as anode catalyst for oxygen evolution } \\
\text { as catalyst } \\
\text { There is some dissipation on the recycling side. }\end{array}$ \\
\hline
\end{tabular}


Table 4. Cont.

\begin{tabular}{cccc}
\hline Classification & Application & PGM & Substitution \\
\hline UPS & Pt [51] & $\begin{array}{c}\text { Uninterrupted power supplies } \\
\text { Reversion to older technology }\end{array}$ \\
\hline OLEDs & Ir organometallics [52] & Pt, Pd also used [53] \\
\hline Medical & $\begin{array}{c}\text { Stents \& } \\
\text { Inserts }\end{array}$ & Pt-Cr [54] & $\begin{array}{c}\text { Due to its corrosion resistance and very rare } \\
\text { allergic reaction this is a desirable material to use } \\
\text { in the body. Pt-Cr have an advantage due to } \\
\text { higher X-ray absorption [55]. Alternative: } \\
\text { Cobalt-chromium material or Nitonol for self- } \\
\text { expanding stents [54]. } \\
\text { Dissipative }\end{array}$ \\
\hline
\end{tabular}

$\begin{array}{cc}\text { Pt, [56] } \\ \text { Pacemakers } & \text { Pt-Ir (10-20\%) [57] }\end{array}$

These are used as pacing electrodes. In addition to the properties listed above, its electrical conductivity makes it desirable to use in these types of devices. Dissipative

These are used to provide a high energy cardioversion pulse for defibrillation [57]. See

Defibrillators $\quad \mathrm{Pt}, \mathrm{Pt}-\mathrm{Ir}$ entry above for properties.

Alternative: Pt-coated Tantalum electrodes [57]. Dissipative

See above for properties.

Brain

Pacemakers

Pt-Ir
Alternative: Silicon electrodes are under investigation $[58,59]$ Dissipative

\section{Dental Fillings}

\section{Pt-Pd (commonly alloyed with}

$$
\mathrm{Au}) \text { [60] }
$$

Pd-alloys(Pd-Cu, Pd-Ag, $\mathrm{Pd}-\mathrm{Ag}-\mathrm{Au})$ [29]
Composites for fillings, $\mathrm{Au}$, Almagums ( $\mathrm{Au}, \mathrm{Mg}$,

$\mathrm{Ag}, \mathrm{Sn}, \mathrm{Cu})$. In some jurisdictions filling compositions may be regulated [60] Dissipative

Iridosmine (65\% (Ir, Os, Ru) and 35\% Pt) [61]. Osmiridium (for example of composition see [63]

Other Fountain pen nib tips $\mathrm{Ir}, \mathrm{Os}, \mathrm{Ru}, \mathrm{Pt}$ for hardening nibs $[61,62]$ is also used [64]. These are chosen for their wear and corrosion resistance. Alternatives: Re and W Dissipative

Electrochemistry-counter electrodes Alternative Ti.

SEM sample coating

Pt electrodes
St [65] Ir

These come in a range of compositions with Pt-Rh v Pt couples or Pt-Rh v Pt-Rh where the Rh content is different.

Also known as Platinel II alloy.

Alternative: Perhaps Re-W based thermocouples might be able to replace the PGM thermocouples, but it depends on the voltage generated in the temperature range of interest.

Ballast sterilization anodes [66] Alternative: other sterilisation methods [67]

\subsubsection{Jewellery}

Jewellery, particularly in China, constitutes the second largest demand for $\mathrm{Pt}$ (also alloyed with Ir at $10 \%$ level). Pt jewellery is a status symbol, so the level of demand for $\mathrm{Pt}$ jewellery fluctuates according to its price relative to gold. $\mathrm{Pd}, \mathrm{Ru}$, and Ir are all used (along with other metals) to harden Pt for jewellery applications [28]. In these alloys, Pt usually 
constitutes somewhere between 85 and $92 \mathrm{wt} \%$ and $\mathrm{Pd}$ up to a few wt\% in alloys. As to substitutes, the desire for this jewellery is probably a mixture of aesthetic appeal and value, so substitution would need to address these two aspects.

\subsubsection{Industrial}

$\mathrm{Pt}, \mathrm{Pd}$, and $\mathrm{Rh}$ are also in high demand in the industrial sector for processes (including catalysts (Section 4.2)) for the production of chemicals, petrochemicals, medical and dental applications, electronic and electrical, and glass manufacture. Figure 2 gives some idea of the breakdown between these different application areas for $\mathrm{Pt}, \mathrm{Pd}, \mathrm{Rh}, \mathrm{Ru}$, and Ir. The applications for Pt and Pd in industrial catalysts and chemicals are almost exclusively as catalysts for the production of fine or commodity chemicals. Petrochemical applications refer to the refining of crude oil to fuels or other petrochemicals for various applications.

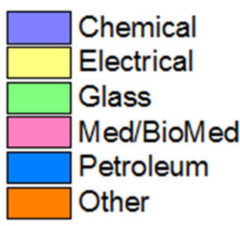

$\mathrm{Rh}$

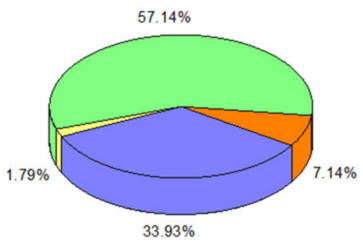

Pt

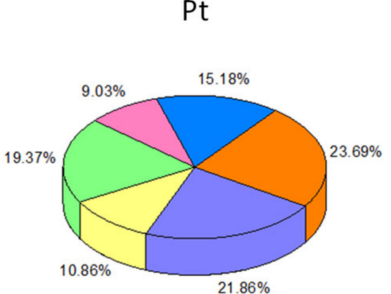

$\mathrm{Ru}$

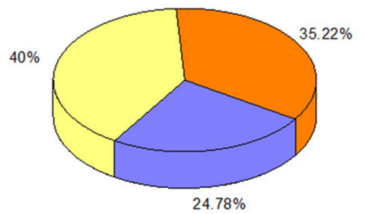

$P d$

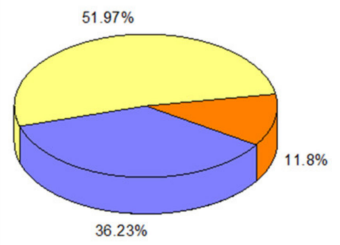

Ir

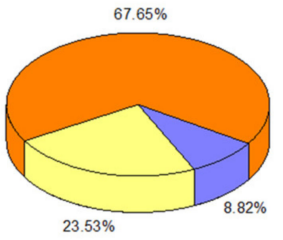

Figure 2. Breakdown by percentage of $\mathrm{Pt}, \mathrm{Pd}, \mathrm{Rh}, \mathrm{Ru}$, and Ir demand for industrial applications for 2018. Total net demand for Pt was 76.4 tonnes, for Pd was 59.6 tonnes, and for Rh 4.8 tonnes, for Ru was 33.5 tonnes, and for Ir was 6.8 tonnes [25].

Glass

In glass manufacture Pt is used in high temperature, oxidation resistant dies particularly for fibreglass, fibre optics manufacture, and crucibles for other glass manufacture. These are generally alloys of $\mathrm{Pt}$ and $\mathrm{Rh}$ with up to $40 \% \mathrm{Rh}$, depending on other additives $[32,68]$. Iridium is used for the most demanding processing conditions, such as single crystal drawing [35], and Li-tantalate filters and oscillators for mobile phones also fall into this category [37]. While there may be some opportunity for substitution in some of the lower temperature applications, such as with refractory oxides, the non-oxidizing and low sticking features of PGM (particularly Pt and Ir) are probably not substitutable.

\section{Electronics and Electrical}

PGMs are used in a variety of electronic and electrical applications [69]. Pt and Ru are used in hard disk manufacture [30,70]. Pt is part of a CoCrPt alloy used for the first layer put down onto the polished $\mathrm{Al}$ substrate (disk) used in perpendicular magnetic recording and enhances the perpendicular field for writing. This layer is separated from a similar layer (third layer) by an atomically thin Ru layer [71]. The demand from this area of technology is uncertain because hard disk technology, which is located on larger storage units, has a complicated competition with solid state devices that are commonly used in portable personal storage devices (e.g., smart phones) or applications requiring fast read-write speeds.

Palladium is used in multilayer capacitor devices (MLCC). While the demand for the capacitors themselves is increasing, design improvements mean that less $\mathrm{Pd}$ is required 
per unit, so Pd demand in this sector is only growing slowly. Pd-Ag, in the form of a paste which is later thermally cured, are used for printed circuitry manufacture [43].

Mobile phones (or Cell phones) contain a number of critical metals including PGMs. $\mathrm{Pd}$ is used in mobile phones at the rate of 15 tonnes/billion mobile phones [72] or 0.009 to $0.015 \mathrm{~g} / \mathrm{unit}$ [42]. Although Tan et al. [73] reported that they did not detect Pd in their study. The ITU report that there is currently approximately one phone for every individual on the planet [74]. The biggest growth and markets for these types of phones is China, followed by India [42]. Clearly mobile phone numbers are growing rapidly along with the amount of Pd sequestered in this technology. With one phone per person on the planet, there may be as much as 135 tonnes of Pd locked away in mobile phones.

$\mathrm{Pt}$ and $\mathrm{Pd}$ are used as catalysts in a range of fuel cell applications, which Johnson Matthey include in the Electronics and Electrical sector [25]. A detailed discussion of the application of fuel cell catalysts in the auto industry is provided later, so only an overview will be presented here. There are two areas of interest here including auto and stationary applications [70]. As would be expected, performance and cost are challenging issues in the auto sector, so it is desirable to maximise the mileage but keep the costs as low as possible by having lower metal content. Currently Pt loadings in the fuel cell stacks have been reported to be around 25 to $35 \mathrm{~g} /$ vehicle $(0.25$ to $0.35 \mathrm{~g} / \mathrm{kW})$ [75]. However, while the stability of $\mathrm{Pt}$ is desirable, the activity of $\mathrm{Pt}$ catalysts is low and not sufficient to achieve the required performance. Thus, $\mathrm{Pt}$ is often alloyed with a transition metal for these applications [45]. For stationary applications, the Pt is alloyed with $\mathrm{Ru}$, which is well known for its dissociative absorption of $\mathrm{H}_{2}[76,77]$. It also reduces the absorption of $\mathrm{CO}$ onto the $\mathrm{Pt}$, which is susceptible to CO-poisoning [70] (Gas poisoning occurs when a gas is strongly or irreversibly absorbed to a site, thus blocking it for reactants).

The volumes of PGM used in these electronic and electrical applications is only about $2-3 \%$ of total PGM usage and is likely to remain at this level. However, if fuel cell technology was to become an important part of the auto industry fuel supply chain, or if the hydrogen economy starts to play a major role, then PGM usage would increase markedly.

Medical

In the medical arena, $\mathrm{Pt}$ is often alloyed with other metals or PGMs for a range of applications. These include stents (base metal alloys are typical, but Pt-Cr is also used) as well as insertion equipment $(\mathrm{Pt}-\mathrm{W})$. Platinum and its alloys are also used as electrodes in a number of applications. For example, it is used in pacemakers (Pt-Ir), implantable defibrillators (Pt-Ir), catheters, treatment of Parkinson's disease (Brain pacemaker) where Pt-Ir alloys are used to deliver electrical impulses, and cochlear implants [78]. In these applications, the alloy may contain up to $20 \%$ Ir. These electrodes are subject to a phenomenon called the foreign body response, which eventually impairs the electrode response, so alternative materials are an ongoing source of research [79]. One material which has been investigated is Tungsten which has been used in animal models, but this shows little prospect of being adopted because of loss of sensitivity over the long term [80]. It is also used in drugs for the treatment of cancers due to its ability to inhibit cell division [78]. The biocompatibilities of $\mathrm{Pt}$, Ir, and other PGMs are reasonably well known [81-84] and are relatively safe.

The medical sector also includes the use of PGM catalysts for the manufacture of pharmaceuticals [85]. For example, ibuprofen and the Anti-Parkinson drug lazabemide are both manufactured using Pd-based catalysts (Table 5). Oxaliplatin, cisplatin, and carboplatin are Pt-containing pharmaceuticals used to treat sarcomas, carcinomas, lymphomas, bladder and cervical cancers, and germ cell tumours. According to Cowley [78], this amounted to 0.71 tonnes of Pt consumption in 2010. The medical use of Pt-based pharmaceuticals results in $\mathrm{Pt}$ dissipation as these are not recovered after treatment. As with the electronics and electrical sector, the total usage is only around $2-3 \%$ of the total Pt market. It is presumed that this application is dissipative as these chemicals end up in the sewer. While the presence of PGM in some waste waters has been investigated using a range of techniques [86], it appears that sewage remediation is more generally focused on heavy metal removal rather 
than having a focus of PGM [87]. This may be because of the low concentrations of PGM in sewage from pharmaceutical sources.

$\mathrm{Pt}$ and Pd are used extensively in dental alloys [60]. Alloy compositions (often regulated) can range from $\mathrm{Pd}$ alloys containing up to $60 \% \mathrm{Pd}$ to gold alloys where the PGM content is less than $10 \mathrm{wt} \%$. While this use may seem dissipative, there are some jurisdictions where environmental laws require the capture of heavy metals, including PGMs, post cremation [88].

Other

Platinum is used in scientific applications as electrodes in electrochemistry, as well as tips in atomic force and scanning tunnelling microscopies, crucibles for high temperature treatment of materials, and heating wires in furnace manufacture.

Ir and Os are used in a range of applications from crucibles for high temperature applications, particularly alloyed with $\mathrm{Pt}$, for the purposes of hardening $\mathrm{Pt}$ with a focus on fountain pen nibs [89]. Iridium is used in both catalysts and crucibles [30]. Iridium was used by Mitsubishi for $\mathrm{NO}_{\mathrm{x}}$ reduction catalysts prior to the introduction of $\mathrm{NO}_{\mathrm{x}}$ absorbers.

\subsection{PGM in Catalysis}

\subsubsection{Chemicals and Environmental Catalysis}

The majority of chemical catalytic reactions involving PGMs are related to the production of some commodity chemicals (such as ammonia production $\left(\mathrm{NH}_{3}\right)$ over $\mathrm{Ru}$ catalysts, ammonia oxidation ( $\mathrm{Pt} / \mathrm{Rh}$ catalysts)), pharmaceutical chemicals (e.g., ibuprofen over a $\mathrm{Pd}$ catalyst), environmental catalysis, (Pt/Pd catalysts), and for agricultural (e.g., Metalochor over an Ir catalyst) chemicals.. The catalytic processes discussed in this section are spread over the industrial, environmental (except autocatalysts), and fine chemical categories in Table 5.

Catalysis is a large field of research, and catalytic processes are of major industrial importance [90]. For example, in the modern chemical industry, nearly $90 \%$ of all chemicals are produced with the aid of catalysts [91,92]. Catalysis can broadly be divided into homogeneous and heterogeneous catalysis, with the latter constituting around $80 \%$ of catalytic processes [91]. In both categories, the activity and selectivity towards the desired product, as well the stability of the catalyst, are key parameters for catalyst performance [92]. As this paper has a focus on the platinum group metals, the examples of various catalytic processes only refer to those processes where a PGM is used. Table 5 summarises many of the homogeneous and heterogeneous catalytic reactions where PGMs are the active catalytic component.

Heterogeneous catalysis is usually performed over dispersed and supported metal crystallites where there is a phase boundary e.g., gas/solid interface. PGMs are used extensively in industrial heterogeneous catalysis [93]. Examples include oxidation of $\mathrm{NH}_{3}$ $(\mathrm{Pt} / \mathrm{Rd}$ or $\mathrm{Pt} / \mathrm{Pd}$ nets), hydrocracking, reforming and isomerization in the petrochemical industry (Pd or Pt/support), and in environmental catalysis, such as either in the autoindustry $(\mathrm{Pt} / \mathrm{Pd} / \mathrm{Ru} /$ support) and / or for remediation of industrial effluent $(\mathrm{Pt} / \mathrm{Pd} / \mathrm{rare}$ earth and other oxides) [92].

Homogeneous catalytic processes are usually considered to have highly dispersed active metal centres (usually as a metal complex) that are dispersed in the same phase as the reactants. The ligands on the metal complex have a role to play in the catalytic process. Homogeneous catalysis is used where there is a need for individual reactions to have a high selectivity towards the product of the reaction. Good examples of homogeneous catalysis can be found in the action of enzymes in biocatalysis. Because of their biological origin, these biocatalysts often use earth abundant metals (rather than precious metals) and can be seen as an avenue for catalyst design inspiration for PGM replacement [94]. Industrial examples are discussed below.

There are numerous different types of homogeneous catalytic reactions, however, as they together constitute only a small amount of total PGM consumption, they will only 
briefly be mentioned here. Moreover, in the chemical industry, some of the reactions to produce monomers (such as the metathesis reaction (Table 5)) have multiple pathways via either homogeneous (Mo, W, or Ru organometallic complexes) or heterogeneous catalytic reactions (Mo or Ru on oxide support). Different pathways may not even involve the same metal ion for the homogeneous and heterogeneous catalysts (e.g., metathesis reactions involving Schrock catalysts (homogeneous) use Mo or W [95], whereas Grubbs catalysts (heterogeneous) use $\mathrm{Ru}[$ [96]).

The environmental catalysis category deals with stationary sources (as opposed to auto) where there are a range of emission problems primarily related to odour control, volatiles, chlorofluorohydrocarbons, and noxious gases such as $\mathrm{SO}_{\mathrm{x}}$ and $\mathrm{NO}_{\mathrm{x}}$ [97]. Pt and $\mathrm{Rh}$ catalysts have been tested on a variety of supports for reduction or oxidation of these pollutants. Of course, the reductant and the effluent gas to be treated have an influence on the choice of metals. For example, $\mathrm{Pt}$ is easily poisoned by $\mathrm{SO}_{2}$ hence other PGMs, such as $\mathrm{Pd}$, Ir, and $\mathrm{Ru}$ are often tested because of their different sensitivity.

Industrial processes in Table 5 cover a wide range of catalyst applications used in industry. Ammonia and ammonium nitrate production is one of the most important applications for PGMs per se, due to significant explosives and fertiliser manufacturing that consumes around 1\% of the world's power production [98]. The importance of ammonia production cannot be underestimated since ammonia is an emerging application for storing hydrogen [99]. While the majority of ammonia production is performed over Fe-catalysts, synthesis over a $\mathrm{Ru} /$ graphite catalyst is also a commercial process [97,100]. In fertilizer production, $\mathrm{Pt}$ and $\mathrm{Pd}$ meshes are used for ammonia oxidation to nitrate as part of ammonium nitrate production [30]. The reduction of aldehydes and ketones to alcohols is another important industrial reaction principally for the high selectivity for reaction of the carbonyl group [101]. Another industrial process is the manufacture of phthalic anhydride, which is used as a precursor for plasticizers in the plastics industry [102]. Hydrogenation of double bonds (particularly linolenic acid) in oils derived from biosources (hardening) is also an important reaction particularly for margarine production. Telomerisation is a catalytic process that is used to limit the degree of polymerization. It is used for the dimerization of 1,3 dienes and specifically 1,3, butadiene for conversion to linear or branched $C_{8}$ chains, which are used for the manufacture of plasticisers. The catalysis can be performed over $\mathrm{Pd} /$ transition metal complexes (homogeneous [103]) or supported (heterogeneous [104]) catalysts.

Table 5. PGM catalyst applications under industrial sector.

\begin{tabular}{|c|c|c|}
\hline Reaction & Catalyst & Comments \\
\hline \multicolumn{3}{|c|}{ Refinery Processes } \\
\hline $\begin{array}{l}\text { Cracking of vacuum distillates for fuels } \\
\text { Naphtha production }\end{array}$ & Pd/H-Y-Zeolite & $\begin{array}{l}\text { Part of the cracking used for petrol and olefinic } \\
\text { gases production. } \\
\text { Alternative: Transition metals/H-Y-Zeolite [90] }\end{array}$ \\
\hline $\begin{array}{l}\text { Reforming of naphtha and isomerization } \\
\text { of light gasoline }\end{array}$ & $\mathrm{Pt} / \mathrm{Al}_{2} \mathrm{O}_{3} / \mathrm{SiO}_{2}$ or Pt/Zeolite & Used for octane increase in fuels \\
\hline $\begin{array}{l}\text { Disproportionation of toluene to benzene } \\
\text { and xylenes }\end{array}$ & $\mathrm{Pt} / \mathrm{Al}_{2} \mathrm{O}_{3} / \mathrm{SiO}_{2}$ & $\begin{array}{l}\text { Terephthaic acid and dimethyl terephthalate, } \\
\text { also used in pharmaceutical industry }\end{array}$ \\
\hline hydrodesulphurisation & $\mathrm{Pt} /$ support & $\begin{array}{l}\text { Desulphurisation of fuels to reduce } \\
\text { auto-catalyst poisoning }\end{array}$ \\
\hline Isomerisation of xylene & $\mathrm{Pt} /$ Zeolite or $\mathrm{Al}_{2} \mathrm{O}_{3}$ & $\begin{array}{c}\text { Used to make para-xylene-a precursor for } \\
\text { polyesters [105]. Ga is also used for } \\
\text { this reaction }\end{array}$ \\
\hline
\end{tabular}


Table 5. Cont.

\begin{tabular}{|c|c|c|}
\hline Reaction & Catalyst & Comments \\
\hline \multicolumn{3}{|c|}{ Environmental Processes } \\
\hline Auto & $\mathrm{Pt} / \mathrm{Pd} / \mathrm{Rh} /$ oxides including $\mathrm{Al}_{2} \mathrm{O}_{3}$ & Exhaust gas remediation [106] \\
\hline VOC removal & $\begin{array}{c}\mathrm{Pt}, \mathrm{Pd} \text { /oxide } \\
\text { supports } \\
\mathrm{Ru}, \mathrm{Rh} / \mathrm{TiO}_{2} \text { for chlorobenzene } \\
\mathrm{Pt}, \mathrm{Rh} / \text { oxide for } \\
\text { formaldehyde } \\
\mathrm{Pt}, \mathrm{Pd} \text { /oxide for } \\
\text { toluene } \\
\mathrm{Pd} \text { /oxide for } \\
\text { Benzene }\end{array}$ & $\begin{array}{l}\text { Removal via oxidation }[91,107,108] \\
\text { Alternative non-catalytic processes } \\
\text { available [109] }\end{array}$ \\
\hline Industrial exhaust & $\begin{array}{l}\mathrm{Pt} / \mathrm{Pd} / \mathrm{Rh} \text { on } \\
\text { various oxide } \\
\text { supports }\end{array}$ & $\begin{array}{c}\text { Exhaust gas remediation [110] } \\
\text { Alternative: Transition metal TWC } \\
\text { (Fe-CuNi) [111,112] }\end{array}$ \\
\hline \multicolumn{3}{|c|}{ Industrial Processes } \\
\hline Ammonia synthesis & $\mathrm{Ru}$ /graphite & $\begin{array}{c}\text { Most ammonia synthesis is performed over } \\
\text { Fe-based catalysts [100] }\end{array}$ \\
\hline Ammonia oxidation & $\mathrm{Pt} / \mathrm{Pd} / \mathrm{Rh}$ metal nets & $\begin{array}{l}\text { Part of ammonium nitrate production for } \\
\text { fertilizers and explosives }\end{array}$ \\
\hline Aldehydes/ketones to alcohol & $\mathrm{Pt}, \mathrm{Pd}, \mathrm{Ru}$ (also Ni) & $\begin{array}{l}\text { Used mainly for solvent production under } \\
\text { reducing conditions [101] }\end{array}$ \\
\hline o-Xylene to phthalic anhydride & $\mathrm{RuO}_{2}$ promoter on $\mathrm{TiO}_{2} / \mathrm{V}_{2} \mathrm{O}_{5}$ & $\begin{array}{l}\text { Ru is one of several possible promoters. } \\
\text { Phthalic anhydride is used as a precursor for } \\
\text { plasticizers in the plastics industry }[92,102] \text {. }\end{array}$ \\
\hline Hydrogenation of bio-oils & $\mathrm{Pd}$ & $\begin{array}{l}\text { Preferential removal of linolenic } \\
\text { acid }[48,92,113]\end{array}$ \\
\hline Caprolactam & $\begin{array}{c}\mathrm{Pd}, \mathrm{Ru} \\
\text { (homogeneous) }\end{array}$ & $\begin{array}{l}\text { Used in nylon fibre fabrication. }[29,114] \\
\text { Alternative methods available }\end{array}$ \\
\hline Cyclohexane Production & $\begin{array}{l}\text { Ru-based } \\
\mathrm{Pd} / \mathrm{Al}_{2} \mathrm{O}_{3}\end{array}$ & $\begin{array}{l}\text { Hydrogenation of benzene to cyclohexane } \\
\text { from nylon [115] } \\
\text { Alternative: } \mathrm{Ni} / \mathrm{Al}_{2} \mathrm{O}_{3}[29]\end{array}$ \\
\hline Toluene diisocyanate production & $\mathrm{Pd}$ & $\begin{array}{c}\text { Hydrogenation of dinitrotoluene-an } \\
\text { intermediate in Toluene di-isocyanate [116]. } \\
\text { Used in a range of products including } \\
\text { polyurethane } \\
\text { Alternative: Raney Ni [29] or } \\
\text { non-catalytic [117] }\end{array}$ \\
\hline
\end{tabular}

\section{Metathesis reactions}

Telomerisation

\section{Ru complex (homogeneous) $\mathrm{Ru} / \mathrm{Al}_{2} \mathrm{O}_{3}$ (heterogeneous)}

$\mathrm{Pd} /$ triphenylphosphine monosulfonate phosphonium complex

$\mathrm{Pd} /$ supported oxides
Used to reorganize $\mathrm{C}=\mathrm{C}$ bonds. Most important example is Olefin metathesis $[95,96]$ Alternative: Mo and W. Nitric Acid Production
(Ostwald process)

$\mathrm{Pt} / \mathrm{Rh} / \mathrm{Pd}$ or $\mathrm{Pt} / \mathrm{Rh}$ gauze

Bulk chemical production of nitric acid [29]

$\mathrm{H}_{2} \mathrm{O}_{2}$ production (Antrachinone process)

Used for dimerization of 1,3-dienes particularly for butadiene which is used as a plasticizer [103] 
Table 5. Cont.

\begin{tabular}{|c|c|c|}
\hline Reaction & Catalyst & Comments \\
\hline \multicolumn{3}{|c|}{ Fine Chemical } \\
\hline Hydrogenation & $\mathrm{Pt}, \mathrm{Ru}$ & $\begin{array}{c}\text { Range of hydrogenation reactions using } \\
\text { different catalysts, e.g., Vitamin manufacture, } \\
\text { carboxcylic acid conversion to } \\
\text { aldehydes }[92,118]\end{array}$ \\
\hline $\begin{array}{l}\text { Reductive amination of aldehydes and } \\
\text { ketones }\end{array}$ & $\mathrm{Pd}$ & $\begin{array}{l}\text { Hydrogenation in the presence of ammonia. } \\
\text { E.g., isophorene diamine Used to make } \\
\text { sealants and adhesives [119] or isophorene } \\
\text { nitrile used for isocyanates manufacture [120] }\end{array}$ \\
\hline Carbonylation of substituted alcohol & $\mathrm{PdCl}_{2}$ based & Production of ibuprofen [78] \\
\hline $\begin{array}{l}\text { Amidocarbonylation of } \\
2,5 \text {,dichloropyridine }\end{array}$ & Pd-Based & Anti-parkinson drug lazabemide [121] \\
\hline Citronella production & $\begin{array}{l}\text { Rh complex } \\
\text { (homogeneous) }\end{array}$ & $\begin{array}{c}\text { One of the main components of citronella oil } \\
\text { which is used as an insect repellent and also } \\
\text { has anti-inflammatory properties. }\end{array}$ \\
\hline Acetic acid and its anhydride & $\begin{array}{c}\text { Rh complex } \\
\text { (homogenous), } \\
\mathrm{Pd} / \mathrm{SiO}_{2} \\
\text { (heterogeneous) }\end{array}$ & $\begin{array}{c}\text { Production of vinyl acetate monomer } \\
\text { Pd catalyst and ethylene as a reactant) [29]. }\end{array}$ \\
\hline Acetaldehyde & $\mathrm{Pd}(\mathrm{II}) \mathrm{Cl}_{2}$ & Homogeneous catalyst [29] \\
\hline Metolachlor & Ir complex & Organic compound used as herbicide [121] \\
\hline 1-Octene production & Pd-complex & Co-monomer in polyethylene production \\
\hline
\end{tabular}

For the fine chemicals area, there are number applications which require high selectivity and only have low product tonnage (compared to other areas in Table 5). Over 50\% of production in this area is for pharmaceuticals, $25 \%$ for agricultural, with the remaining $25 \%$ being roughly evenly divided between flavours and fragrances, dyestuff and pigments, food additives, and other residual processes [92]. Hydrogenation reactions are used to produce $10-20 \%$ products including hydrogenation of nitro compounds, asymmetric catalysis, and selective hydrogenation of olefinic bonds with the majority of these reactions being performed over Pd catalysts, although other catalysts may also be used. One important hydrogenation reaction is the reduction of nitrobenzene used in aniline dyes, explosives, and drug manufacture. Because it is a significant environmental pollutant, its reduction is important [122]. Another reaction is the production of $\Upsilon$-Valerolactone (GVL) from levulinic acid. GVL is used as a fuel additive, in perfumes, and as food additives [118], and it can be produced from a Ru-based catalyst. Asymmetric catalysts are used extensively in the pharmaceutical industry to produce optically pure compounds such as drugs. For example, the S-isomer of Naproxen, used for pain relief, is innocuous, whereas R-isomer is a liver toxin. Another important asymmetric reaction is menthol production, which is performed over an Rh-catalyst. These homogeneous catalysts are expensive because the ligands that are attached to the metal centres are fine chemicals themselves. The catalysts are relatively easy to recover as they are often used in batch processes and recovery is part of the manufacturing process where they are reactivated for the next batch. Acetaldehyde used as a starting material for acetic acid and ethyl-acetate-vinyl-acetate ester manufacture is produced over a $\mathrm{PdCl}_{2}$ catalyst. Hydroformylation (combining $\mathrm{CO} /$ olefin coupling) can be performed using an $\mathrm{Rh} /$ Phosphine catalyst. Acetic acid can be generated from methanol and CO over an Rh carbonyl catalyst or Ru-Ir catalyst [6]. Acetic acid is important, itself, but also in a number of processes, including for the production of vinyl acetate, as mentioned above. Suzuki coupling of aryl groups can be performed over a Pd complex. 


\subsubsection{Petroleum}

Table 5 summarises reactions and catalysts used in the refinery sector of industrial applications. Distillation of different fractions of crude oil is a key industrial process including naphtha production (liquid distillate). Cracking of distillates, sourced from crude oil and naphtha reforming, are two of the most important processes in modern industrial catalysis, particularly for the production of fuels $[123,124]$. Pd on the zeolite mordenite is one catalyst that is used for cracking. Isomerisation is important for increasing the octane rating by producing branched products from the linear alkanes. Pt on acidified mordenite or alumina/silica mixtures is used in isomerisation reactions to increase the amount of paraxylene in a mixture of ortho-, meta-, and para-xylene, which is subsequently used as a precursor for polyethylene terephthalate (PET).

The lifecycle of catalysts used in hydrocarbon manufacturing is generally long. The main cause of deactivation of these types of catalysts is the build-up of carbonaceous material (coke) on the catalyst itself. Reactivation of the catalyst is usually addressed by a regeneration process where the catalyst undergoes an oxidation cycle to burn off the carbon resulting in $\mathrm{CO}_{2}$ [3]. Coke removal can also be achieved by treatment in the presence of $\mathrm{H}_{2}$ at elevated temperature, resulting in the formation of methane [125]. With oxidative regeneration the catalyst can be reactivated several times, resulting in several operational lifetimes before replacement.

\subsection{Auto-Catalysts}

When auto catalysts are the topic of discussion, the focus is usually on current ICEV catalysts for treating exhausts to reduce emission of chemicals such as NOx and SOx and, in the case of diesel vehicles, carbon particulate emissions. Given the domination of ICEVs in the auto market, this focus on auto catalysts is understandable. However, the auto market is seeing the beginning of a long-term transition from ICEVs, powered by fossil fuels, to EV using batteries in battery electric vehicles (BEV) or hydrogen as a source in a fuel cell electric vehicle (FCEV). This is largely driven by a thrust to reduce $\mathrm{CO}_{2}$ emissions. The reliance on Pt for both ICEVs and FCEVs applications is a cause for concern, as mentioned in some studies [126].

The importance of moving away from fossil fuels is now self-evident with continually rising $\mathrm{CO}_{2}$ emissions, which, for the vehicle sector, constitute $15 \%$ of the total global $\mathrm{CO}_{2}$ emissions [127]. The vast majority of which could be eliminated with a change to BEV (if the charging uses renewable electricity) or FCEV where the $\mathrm{H}_{2}$ for refuelling is not derived from fossil fuels. Indeed, national programs and international efforts (such as the EVI, which involves 13 countries [128]) are devoted to accelerating research and development into these alternative areas [129], as well as the efforts by IPHE (The International Partnership for Hydrogen and Fuel Cells in the Economy), which involves 21 countries [130]. As noted above, the uptake of EVs has been slower than anticipated, and at the time of writing, EVs are not a huge percentage of the market (around $4.2 \%$ passenger cars sold in 2020 were BEVs or plug-in hybrid vehicles (PHEVs)). However, they represent an important emerging part of the world market and are therefore included in a summary of the use of PGMs. The hydrogen economy itself may also see increased use of $\mathrm{Pt}$, Ir, and $\mathrm{Ru}$ for the production (electrolysers) and utilization (fuel cells) of hydrogen in the electrode catalysts [131].

Perhaps surprisingly, the major portion of PGMs used in EVs are for catalyst applications, but in the EV case, these catalysts facilitate reactions at electrode interfaces both in FCEVs and potentially BEVs. Figure 3 shows a schematic comparison of PGM usage in various types of light auto vehicles (pink boxes). For ICEVs, the majority of use for PGMs is in catalysts for exhaust emission control (Pt, Pd, and Rh), while it is for electrode catalysts for FCEVs. With BEVs, the current Li-based systems do not require Pt, but its use would improve efficiency of the anode (hydrogen dissociation) and cathode (oxygen reduction reaction $\left(\mathrm{O}_{2}+4 \mathrm{e}^{-}+4 \mathrm{H}^{+} \rightarrow 2 \mathrm{H}_{2} \mathrm{O}\right.$ (four electron pathway)) and thereby overall efficiency $[132,133]$. With the increasing technology and automation of driving embedded into modern light vehicles, there is also an increase in the amount of PGM in the electronics 
and electrics [134]. In fact, this is not confined to the PGMs. For example, Ortego et al.

have identified over 60 metals used in modern vehicle manufacture $[135,136]$.

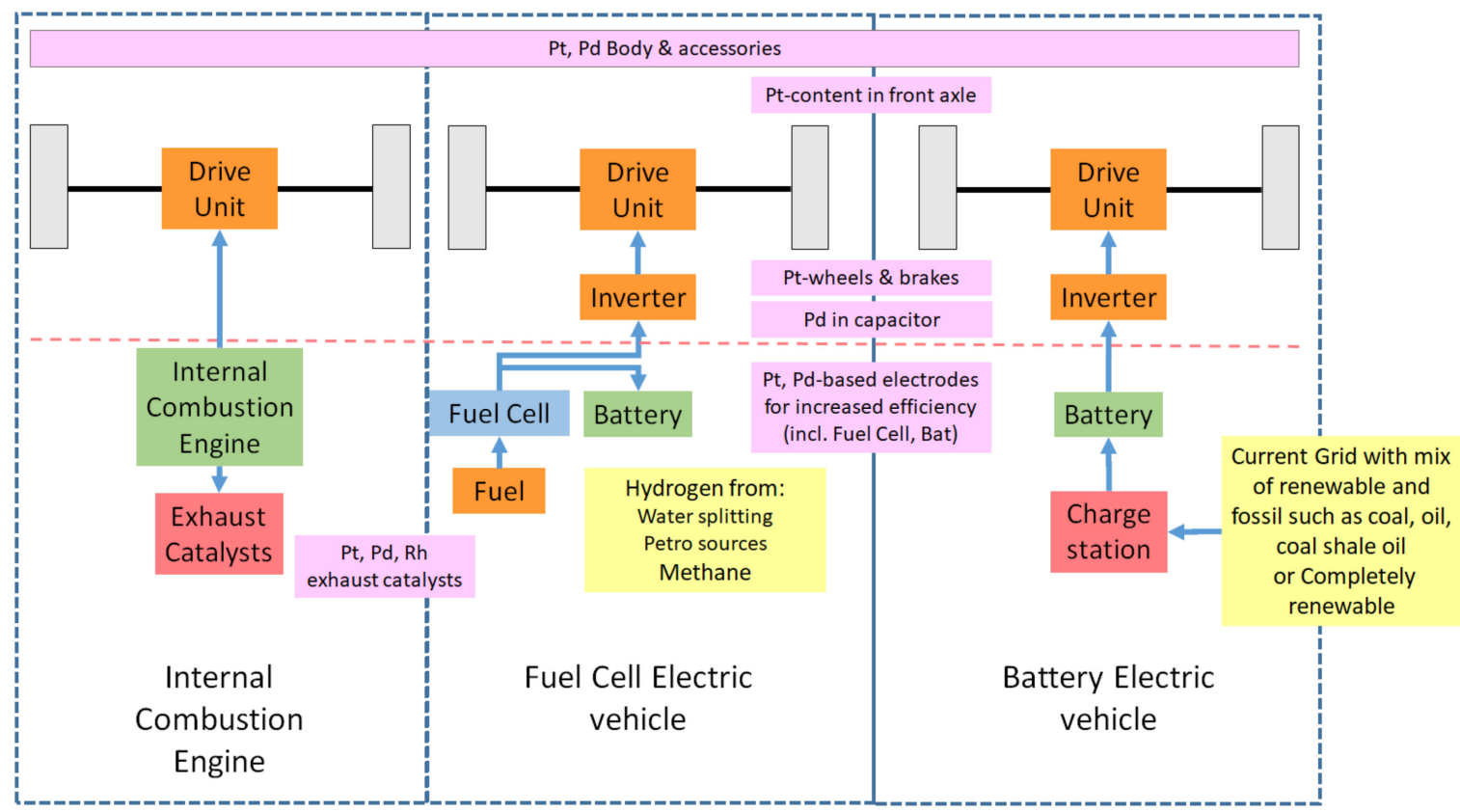

Figure 3. Schematic of where PGMs are used in light vehicles, comparing an internal combustion engine vehicle (ICEV), with a fuel cell (FCEV), and battery electric (BEV) vehicles.

\subsubsection{Internal Combustion Engine Vehicles (ICEV)}

The largest single demand for PGMs comes from the auto industry, particularly for use in catalytic converters for exhaust gas treatment. The auto-catalysis figure does not include indirect PGM usage (particularly Pt) that contributes to auto manufacture, such as in fibre glass manufacture for composite materials for car bodies, PGM-based catalysts for polymer production [14], spark plugs [14], PGM metals in catalysts used in refining fuels [92], or those used in the electrics and electronics. All these are included in the industry sector.

The demand for PGMs in auto-catalysts has been driven largely by auto-emission regulation, which has changed considerably over the years and continues to change. Initially, $\mathrm{CO}$ and hydrocarbon oxidation were all that was required under early autoexhaust regulation, but this moved to stricter requirements for lower $\mathrm{NO}_{\mathrm{x}}$ emissions eventually requiring catalytic conversion of the $\mathrm{NO}_{x}$ as opposed to further engine design modification, which could not achieve the emissions requirements [25]. This change led to the three-way catalytic converter in the 1980s [137,138]. Diesel engines provided some of the biggest challenges since they required, in addition to the removal of other emissions, removal of carbon.

Taking Europe as an example, the changing requirements for light diesel vehicles is depicted in Figure 4. Under early regulation, only a diesel oxidation catalyst (DOC) was required. However, around 2010, most vehicles also required a particulate filter (DPF). Further changes resulted in different catalyst design strategies where lean burning conditions for oxidation of $\mathrm{NO}_{x}(\mathrm{LNT})$ were implemented; all these catalysts required PGMs as described below, but the mix of metals and catalyst types has led to a complex demand for Pt, Pd, and Rh. However, the increase from 222.4 t/a in 1998 to 299 t/a in 2019 is dominated by increased use of $\mathrm{Pd}$ arising from greater demands for emission control, particularly for light duty petrol engines in China [139], as well as increased overall auto production [25]. The increased Pd demand resulted in large Pd price increases. The overall outcome resulted in an increased use of PGM, as can be seen in Figure 5, for the period 1998 to 2019. Since 1998, Pt and Rd consumption has been consistently between 50 and 
$100 \mathrm{t} / \mathrm{a}$ and 20 and $30 \mathrm{t} / \mathrm{a}$, respectively (Figure 5). Indeed, the price increases in PGMs has led a number of auto manufacturers to drop diesel vehicle manufacturing altogether [27].

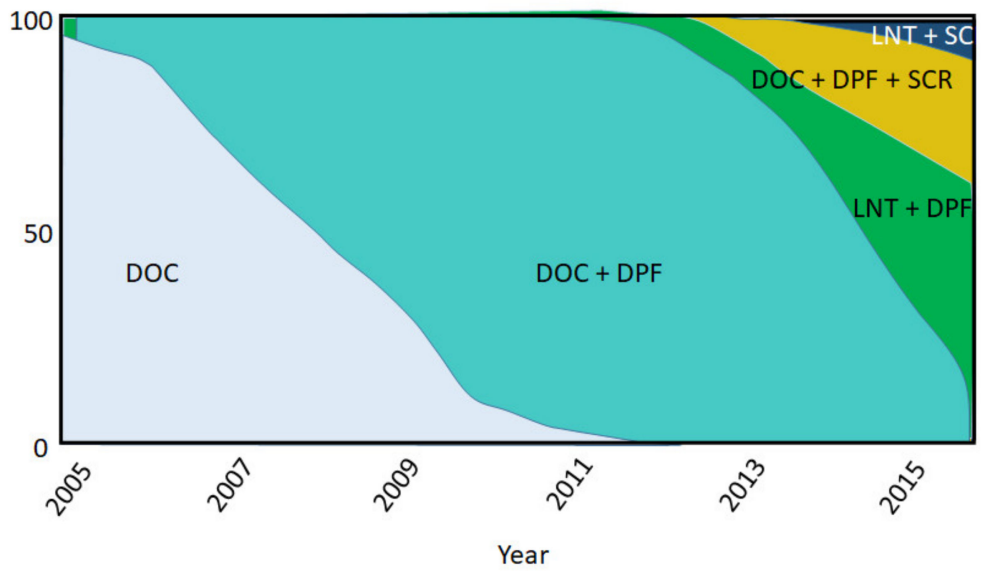

Figure 4. Breakdown of catalysts type in light diesel autos in Europe (after Johnson Matthey [139]). The introduction of stricter regulation has led to the introduction of new technology. DOC = diesel oxidation catalyst (Pt and Pd varying amounts), DPF = diesel particulate filter (Pt and Pd), and LNT = Lean NOx trap (Rh). Selective Catalytic Reduction (SCR) includes JM technology, but it is not a PGM-based catalyst.

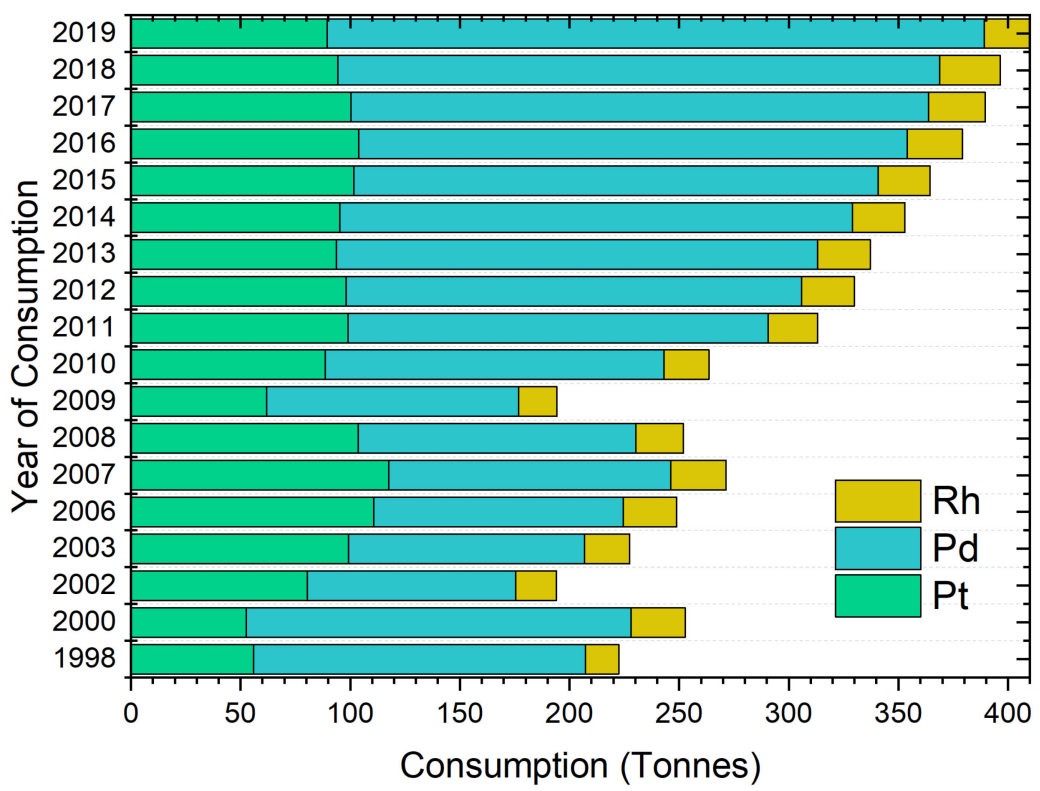

Figure 5. Tonnes of PGM used in auto-catalysts during the period 1998 to 2019. N.B. All data originally from Johnson-Matthey [25], but 1998 to 2003 from [138]. Note-vertical axis is not linear due to years 1998 and 2000.

In Figure 6, demand for PGM in diesel vehicles is broken down by region. In terms of Pt demand for auto-catalyst manufacture, Europe has the consistently highest demand, followed by the rest of the world (RoW), Japan, North America, and then China (Figure 6a). Most regions have a dip around 2009, which coincides with the significant substitution of Pd for Pt. However, it also overlaps with the GFC where demand for cars may have been lower. Pd consumption for auto-catalyst manufacture shows a considerable increase in all regions, apart from Japan, from 2009 (Figure 6b). Interestingly, the Pd/Pt by region, shows very high values in China followed by North America (Figure 6c). In China, the high $\mathrm{Pd} / \mathrm{Pt}$ ratio indicates that auto-catalysts have higher Pd loadings than elsewhere in 
the world. This is odd since the higher S contents reported for fuels in China compared to the rest of the world would lead to greater poisoning, which should be a driver for greater Pt loadings [140]. Higher PGM levels would be required to get a similar emissions outcome. Europe and Japan have the lowest $\mathrm{Pd} / \mathrm{Pt}$ ratios and the strictest regulatory regimes, but also low sulphur content. PGM demand for 2020 was lower than recent years and is attributed to the global Covid-19 pandemic [27].

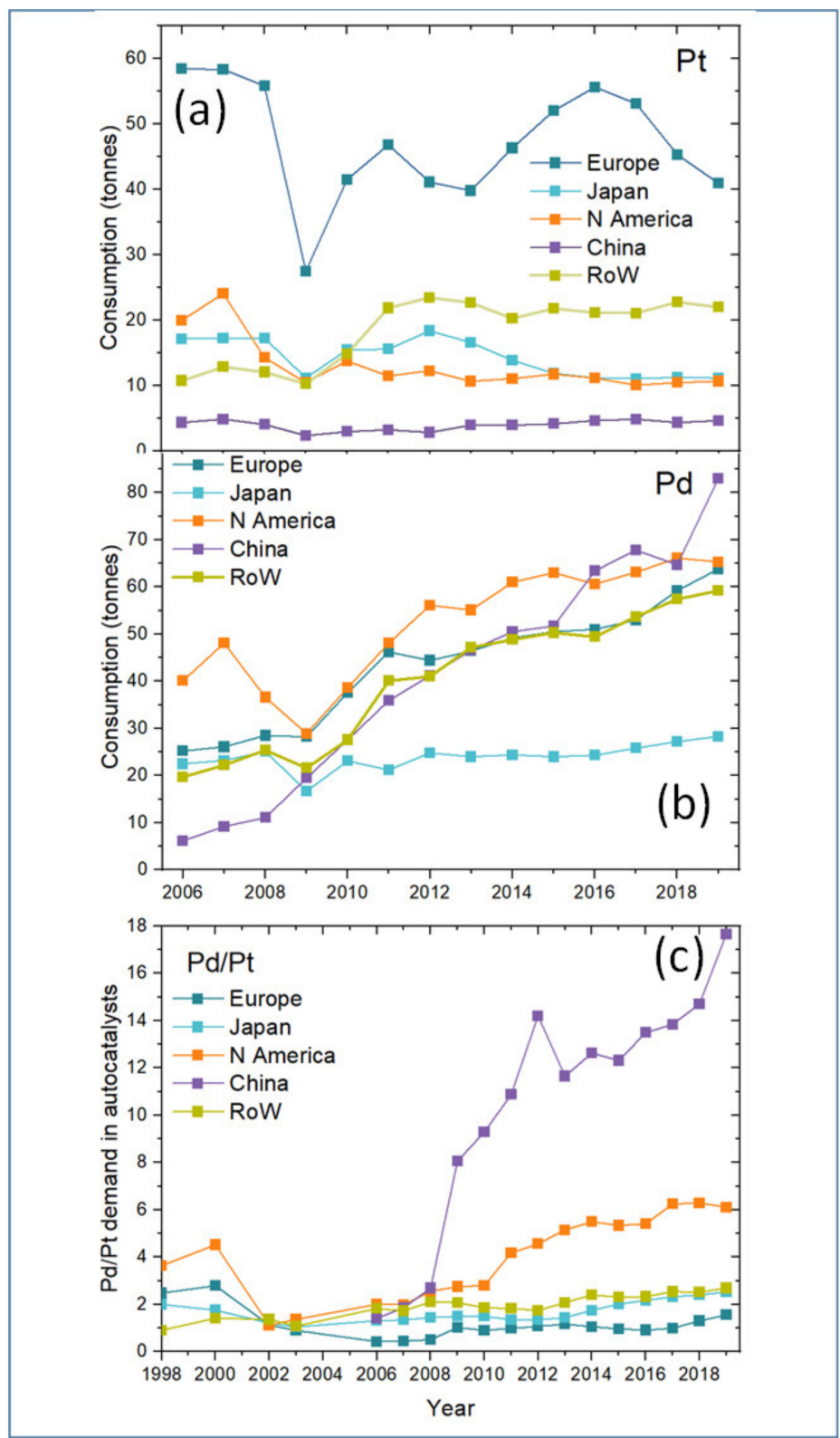

Figure 6. (a) Pt and (b) Pd demand for auto-catalysts, by region, between 2006 and 2019. (c) Pd/Pt ratio for demand by region from 1998 to 2019.

$\mathrm{Pt}$ and $\mathrm{Pd}$ are used in the auto industry to reduce carbon monoxide (CO) and unburnt hydrocarbons (HC) emissions by oxidation to $\mathrm{CO}_{2}$ and water $[137,139]$. $\mathrm{Rh}$ is primarily used in $\mathrm{NO}_{x}$ reduction and is not usually substituted by $\mathrm{Pd}$ or Pt $[14,138]$. Lean burn engines increase the amount of $\mathrm{NO}_{x}$ generated, hence higher catalyst loadings are required to eliminate this $\mathrm{NO}_{\mathrm{x}}$. However, the early expansion of diesel engine usage (1990 to 1996) has meant that demand didn't increase at the pace that regulatory frameworks were driving towards lower emissions for petrol engines and, therefore, higher catalyst loadings. The 
reason behind this is that diesel engines were able to meet early emission standards in Europe (Euro 1) via engine adjustment [25].

According to Böck, the choice of PGMs for auto-emission catalysis is underpinned by:

1. high activity of these metals under high flow and short residence time of the exhaust gas over the catalyst,

2. resistance to poisoning (particularly by Sulphur compounds),

3. they are less prone to deactivation by interaction with the support and sintering,

4. they have significant activity at temperatures as low as $220^{\circ} \mathrm{C}$ (around 400 to $500^{\circ} \mathrm{C}$ lower than thermal oxidation).

Restrictions on the emission of $\mathrm{NO}_{x}$ led to the development of the three-way catalyst (TWC) for light duty ICEVs where Rh played the important role of $\mathrm{NO}_{x}$ reduction [141]. Indeed, stricter limits on $\mathrm{NO}_{\mathrm{x}}$ emissions led both to higher PGM loadings on TWC catalysts, as well as inclusion of diesel ICEVs (e.g., Euro VIb regulations on light duty diesel vehicles). It also led to the introduction of the DPF and the DOC both of which use Pt and Pd [139]. Moreover, improved fuel quality (less S) led to the substitution of Pt by Pd, which introduces an interplay on demand between these PGMs [142]. This substitution was initially driven by cheaper Pd prices than Pt. However, this situation has changed considerably with significant increases in Pd prices, which are nearly 2.5 times the price of $\mathrm{Pt}$ at the time of writing this article.

The most widespread method of removing $\mathrm{NO}_{\mathrm{x}}$ in petrol driven light automobiles (where PGMs are used) is through a TWC which is run under lean burn conditions. This system will reduce $\mathrm{NO}_{x}$ emissions but, in addition, oxidises both $\mathrm{CO}$ and any hydrocarbons to $\mathrm{CO}_{2}$ and water [143]. Of course, the type of reaction that occurs will depend on the air-to-fuel ratio (A/F) [138]. Stoichiometric feed occurs with air to fuel ratio of 14.7 and lean conditions at $\mathrm{A} / \mathrm{Fs}>14.7$. Under normal operation, the $\mathrm{NO}_{\mathrm{x}}$ are converted to nitrates and stored on an alkali earth (e.g., Ba) or alkali metal (K) component of the support. During short periods where the engine is operated with an $\mathrm{A} / \mathrm{F}<14.7$, the nitrates are reduced to $\mathrm{N}_{2}$ and water over a Ru catalyst, although mixed PGMs are also reported [143]. The reactions on this system include (note that $\mathrm{Pd}$ can be substituted for $\mathrm{Pt}$ ):

$$
\begin{gathered}
\mathrm{NO}+0.5 \mathrm{O}_{2} \stackrel{\mathrm{Pt}}{\rightarrow} \mathrm{NO}_{2} \rightarrow \text { N-oxidation } \\
\mathrm{NO}_{2}+\mathrm{MCO}_{3} \stackrel{\mathrm{Pt}}{\rightarrow} \mathrm{MNO}_{3}+\mathrm{CO}_{2} \rightarrow \mathrm{N} \text {-storage (alkali earth or alkali metal) } \\
\mathrm{MNO}_{3}+\mathrm{H}_{2} \stackrel{\mathrm{Pt}}{\rightarrow} \mathrm{MO}+\mathrm{NO}+\mathrm{H}_{2} \mathrm{O} \rightarrow \text { Trap regeneration }(\mathrm{A} / \mathrm{F}<14.7) \\
2 \mathrm{NO}+2 \mathrm{H}_{2} \stackrel{\mathrm{Rh}}{\rightarrow} \mathrm{N}_{2}+2 \mathrm{H}_{2} \mathrm{O} \rightarrow \text { Trap regeneration }(\mathrm{A} / \mathrm{F}<14.7) \\
\mathrm{MO}+\mathrm{CO}_{2} \stackrel{\text { Pt }}{\rightarrow} \mathrm{MCO}_{3} \rightarrow \text { Trap regeneration }(\mathrm{A} / \mathrm{F}<14.7) \\
\mathrm{MCO}_{3}+\mathrm{SO}_{3} \stackrel{\text { Pt }}{\rightarrow} \mathrm{MSO}_{4}+\mathrm{CO}_{2} \rightarrow \text { Sulphate Build-up }
\end{gathered}
$$

The oxidation catalysts contain $\mathrm{Pt}$ and $\mathrm{Rh}$ or $\mathrm{Pt}, \mathrm{Pd}$, and $\mathrm{Rh}$ where the $\mathrm{Pd}$ substitutes for the Pt [139]. The Rh catalyst (reaction (4)) may be mixed metal and higher loadings lead to greater $\mathrm{NO}_{x}$ reduction at lower operating temperature [106]. They have an alkali or alkali earth component used for storing the $\mathrm{NO}_{x}$ during normal operation which is oxidized to $\mathrm{NO}_{2}$, reacting with the alkali or alkali earth to form nitrates (reactions (1) and (2)) [106]. When lean conditions are imposed (A/F ratio is decreased), a reducing environment is imposed, and the nitrates react with the hydrocarbons and $\mathrm{CO}$ to reduce them to $\mathrm{N}_{2}$. Catalysts typically have 0.1 to $0.3 \mathrm{~g} \mathrm{Ru} / \mathrm{L}$ of catalyst and 3.5 to $4.0 \mathrm{~g} / \mathrm{L}$ for the $\mathrm{Pt}$ or Pt/Pd component [106]. The introduction of Pd occurred in the mid-nineties and coincided with the introduction of S-lean fuels. $\mathrm{Pt}$ is more resistant to $\mathrm{S}$ poisoning than $\mathrm{Pd}$, so a reduction in $\mathrm{S}$ content of the fuel was necessary for $\mathrm{Pd}$ to be introduced. In larger vehicles, a non-PGM catalyst is used for $\mathrm{NO}_{\mathrm{x}}$ reduction based on urea and will not be further discussed here. There are ongoing issues with catalyst design, particularly with 
deactivation during air flow over the catalyst, where Rh dissolution into ceria, zirconia, or sintering may occur [141], as well as efficiency improvements in internal combustion engines which lead to lower catalyst operating temperatures [137].

PGMs are also used in light duty diesel engines. These engines have a high fuel efficiency and historically low CO emissions which in earlier times saw them as "green" vehicles. As diesel engines operate under very lean conditions, $\mathrm{CO}$ and unburnt hydrocarbons are burnt off in the following reactions:

$$
\begin{gathered}
\mathrm{CO}+0.5 \mathrm{O}_{2} \stackrel{\text { Pt }}{\rightarrow} \mathrm{CO}_{2} \\
\text { Hydrocarbon }+\mathrm{O}_{2} \stackrel{\text { Pt }}{\rightarrow} \mathrm{CO}_{2}+\mathrm{H}_{2} \mathrm{O}
\end{gathered}
$$

The main problem area for diesel engines is the generation of carbonaceous particulate material (PM) with absorbed hydrocarbons (some of which are partially oxidized), sulfuric and nitric acids which have been associated with health hazards [138]. These particulates are generally caught in a particulate trap where they undergo oxidation either at regular intervals (of distance) or even continuously. This cycle involves increasing the trap temperature to over $550{ }^{\circ} \mathrm{C}$ for the following reactions to occur:

$$
\begin{gathered}
\mathrm{PM}+0.5 \mathrm{O}_{2} \stackrel{\mathrm{Pt}}{\rightarrow} \mathrm{CO}_{2}+\mathrm{H}_{2} \mathrm{O} \\
\mathrm{NO}+0.5 \mathrm{O}_{2} \stackrel{\text { Pt }}{\rightarrow} \mathrm{NO}_{2}
\end{gathered}
$$

The key reaction here is reaction (10) where the generation of $\mathrm{NO}_{2}$, which is a strong oxidant, over a Pt catalyst facilitates the reduction of the PM at much lower temperatures (as low as $250^{\circ} \mathrm{C}$ ) than thermal oxidation. Partial replacement of Pt by Pd is used in many of these catalysts.

\subsubsection{Electric Vehicles}

The IEA reported that, in 2020, there were 7.2 million electric vehicles (EV) on the road with nearly half in the People's Republic of China [128]. While these figure are small in terms of total EVs (2.6\% of the total market [128]) they represent the changing future. The rate of uptake of EVs has been much slower than anticipated. In Victoria, Australia, one study in 2012, for example, based on reasonable assumptions, predicted that electric vehicles of all types would constitute around $25 \%$ of the auto market by 2020 [144]. However, in 2020 the actual figures for EVs (dominated by BEVs) were only around $0.2 \%$ of the total market, highlighting the slow uptake of these types of vehicles. Victoria is not the only jurisdiction witnessing a slow uptake in EVs; this experience is observed in many places around the world [145]. There seems to be a number of reasons for this laggard uptake including, range anxiety, charging infrastructure concerns, and disappearing government incentives to name a few [128,144,145].

EVs are divided into battery EVs (BEV), hybrid EVs (HEVs), plug-in hybrid EVs (PHEV), and fuel cell EVs (FCEV) [146]. In the fuel cell category, there are a number of fuel cell technologies that exist for a range of stationary and non-stationary applications. These are classified by the type of electrolyte [147]. They include polymer electrolyte membrane fuel cell (PEMFC), solid oxide fuel cell (SOFC), phosphoric acid fuel cell (PAFC), molten carbonate fuel cells (MCFC), direct methanol fuel cells (DMFC), alkaline fuel cells (AFC), and reversible fuel cells (RFC) [148-150]. Since some of these fuel cells do not employ PGMs because they operate at elevated temperature (SOFC \& MCFC) they will not be discussed further [148]. While PAFCs use Pt catalyst [147] they are currently used for stationary applications and will not be discussed further here except to say that the electrode catalysts used in PAFCs are subject to the same problems as Pt catalysts on electrodes used in other fuel cells [151]. AFCs and PEMFCs, both use a carbon supported Pt-metal catalyst. The amount of $\mathrm{Pt}$ required in AFCs, due to better kinetics, is only $20 \%$ compared to in PEMFC [152]. Alternatives include Co and Fe Phthalocyanine [153]. DMFCs use Pt-Ru 
catalysts [154] or Pt-Co/Pt-Ni catalysts [155]. RFCs can use PGM catalysts, but transition metal electrode catalysts are also under investigation [156].

Fuel cells that operate at lower temperatures require good catalysts at electrodes for oxygen and hydrogen dissociation reactions that eventually lead to the formation of water. Of the two reactions the oxygen dissociation (or better known as the oxygen reduction reaction (ORR)) is the more tardy and has been the subject of intense research [157]. Pt reduces the overpotential required for oxygen reduction [132,158]. According to Wagner et al. [157], who give an excellent review of the catalysis requirements of the electrode catalyst, the highest ORR kinetics are obtained on smooth Pt surfaces rather than at "defect sites" such as steps, kinks, and edges, often associated with heterogeneous catalysis. The optimization of these catalysts, therefore, is about optimising the Pt-active sites rather than generating highly dispersed $\mathrm{Pt}$ such as in atomic dispersion or small 3D particles.

PEMFC which are viable candidates for auto applications, uses a Pt catalyst or Pt$\mathrm{Ru}$ catalyst where CO levels are likely to be high [147]. The development of alternative electrode catalysts still relies on some Pt being present. Alternatives include Pt-transition metal catalysts in binary or ternary compositions $[45,159]$. Hou et al. [45] point out that the overall loading of PGM as a catalyst in a fuel cell makes this technology competitive with PGM autocatalyst loadings (ICEV) for exhaust emission control. Recent work in the US points to $\mathrm{M}-\mathrm{N}_{\mathrm{x}}$ sites (particularly Fe-N clusters [129]) on graphitic carbon as a potential alternative [48,160]. PGM loading of fuel cells has been significantly reduced over the last couple of decades to close to $0.3 \mathrm{~g} / \mathrm{kW}$. US, Japan, and China, in their respective roadmaps have all set a target of PGM loadings below $0.125 \mathrm{~g} / \mathrm{kW}$ by 2030 [161]. This loading is close to the PGM quantities currently used in the ICEVs of around 5 to $10 \mathrm{~g} /$ vehicle. Therefore, the achievement of these targets for platinum loadings would not result in a substantial increase in platinum demand. As the PEMFC for both stationary as well as transport applications are operated at temperatures below $70-80{ }^{\circ} \mathrm{C}$, the dissipation of PGMs to atmosphere is expected to be substantially lower. The recycling of the PGMs from PEMFCs is an active area of research, as described below [162].

\section{Battery Electric Vehicles (BEVs)}

Almost 50 metals have been identified in the production of BEVs, some of which are critical for production. 1.2 tonnes of metal were used in a Li-battery operated light vehicle, coining the term "road-mine" [136]. BEV demand for PGMs is confined to their use in electronic components, as noted above. Iglesias-Embil et al. [136] show that PGMs are used in a Li-battery BEV in the front axle, wheels and brakes, body, electrics \& electronics, and accessories, with the vast majority being used in the electrics and electronics. Ortego further includes foot adjustment mechanism, airbag circuitry, and rain, speed, and temperature sensors, with some of these included in the front axle, wheel, and brake systems mentioned above [135]. For example, in the drive train, the invertor must be de-coupled from the battery DC source using a DC-link capacitor. Pt can be used as a thin film electrode in one version of this capacitor [163]. Moreover, it has been reported that PGMs (principally $\mathrm{Pt}$ ) may improve electrode kinetics for Li-batteries which has engendered recent market interest [164]. The overall loadings of PGMs in a Li-battery powered BEV for $\mathrm{Ru}, \mathrm{Rh}$, and Pt are $<0.1 \mathrm{~g} /$ vehicle and between $0.1 \mathrm{~g}$ and $1 \mathrm{~g}$ for Pd [136] with only Ru showing an increased demand with respect to an ICEV and Pt remaining at similar levels.

Related to BEV, its charging infrastructure [165] will still have some electronic circuits/capacitors/equipment that may use some PGMs; otherwise, the major equipment used in the fast chargers is the AC/DC invertors.

\section{Fuel Cell Electric Vehicles (FCEVs)}

Hydrogen powered FCEVs are potential substitutes for ICEVs [166-168]. As described above, uptake has been slow. Miller, for example reported that there were 14,000 hydrogen powered vehicles worldwide [129], although IEA estimated 25,000 at the end of 2019 [169]. In terms of propulsion, using $\mathrm{H}_{2}$ via either direct combustion or through fuel cell technology 
are considered as candidates for future autos [170]. Currently, the vast majority of hydrogen is produced via steam-methane reformation that has a considerable carbon footprint, so the hydrogen fuel for FCEVs needs to be sourced from renewable processes to have a carbon footprint benefit over ICEVs, for example, directly from water splitting [171]. Electrolysers for hydrogen production are another technology that is being deployed worldwide on the tens of MW scale. PEM based electrolysers also use PGM group metals such as Pt and Ir $[19,50]$. The demand for these metals will grow at a rapid rate with the further uptake of this technology for hydrogen production from renewable electricity sources such as solar PV and wind generators [169].

FCEVs have a higher demand for Pt than EVs or vehicles running on fossil fuels (up by $0.6 \%$, according to Zhang et al. [45]), but figures vary. Hou et al. [45], for example, suggest that it is $12.5 \mathrm{~g} /$ unit as opposed to ICEVs at between 5 and $10 \mathrm{~g} / \mathrm{unit}$, while on the other hand, Notter et al. [171] suggest $14.3 \mathrm{~g} /$ unit for FCEVs versus 4 to $9 \mathrm{~g} /$ unit for ICEV. Wittstock et al. [162] determined that the figure for PEMFC EVs is $11.2 \mathrm{~g} /$ vehicle but noted that some assessments indicate loadings as high as $42 \mathrm{~g} /$ vehicle. A value of $33.76 \mathrm{~g}$ is obtained using the figures of Simons and Bauer $\left(225 \mathrm{~cm}^{2}\right.$ electrode area and $0.15 \mathrm{~g} / \mathrm{cm}^{2}$ $\mathrm{Pt}$ ) [172] which is similar to values reported by Banham et al. [75]. There is an ongoing drive to reduce PGM loadings and a number of different methods for catalyst preparation with lower Pt loadings being are either reviewed or discussed in the literature [75,159,173-176].

\subsection{Substitution for PGMs}

Substitution for PGMs is a broad topic and a good general overview of potential substitutes is provided by Nassar et al. [6]. The focus in this section will be on substitution in the catalytic processes described above.

The search for substitutes for PGMs in many catalytic processes is complex and requires some understanding of the catalytic process. One aspect of catalytic activity is in metal dispersion. It might be thought that, in many heterogeneous catalytic processes, activity might be optimized by the greatest level of atomic dispersion of the active metal, thereby providing the opportunity for every metal atom to be involved in the catalytic reaction. However, this view is not applicable to all catalytic reactions because it ignores the role of surrounding metals atoms at an active site as well as the role of the support and promoters. A good example of this is in ammonia synthesis where the Fe-based catalyst, with promoters, works by dissociative absorption of both $\mathrm{N}_{2}$ and $\mathrm{H}_{2}$ and successive hydrogenation of atomic nitrogen [177-179]. This means that there needs to be adjacent sites containing enough atomic hydrogen for the synthesis to occur. Moreover, the active metal sites for $\mathrm{N}_{2}$ dissociation are not just any site on the surface but have preferred crystal orientations. This brief summary provides more insight into the issues of substitution at the atomic to nanometric scale, which puts the issues of substitution into perspective from the catalytic perspective.

Ammonia synthesis on Fe has been studied extensively, and the discovery of the mechanism formed the basis of a Nobel Prize. The scission of the $\mathrm{N} \equiv \mathrm{N}$ triple bond is highly structure sensitive, that is, on Fe single crystals it requires particular sites for the dissociation reaction to proceed. The optimum site is a surface Fe atom surrounded by seven other Fe atoms labelled as $C_{7}$ in Figure 7 a [180]. The number of $C_{7}$ sites increases with open surface structures such as the $\mathrm{Fe}(111)$ plane, which has the highest activity of any of the Fe single crystal planes (Figure 7a). The $C_{7}$ sites comprise second and third layer Fe atoms such that a hollow is formed in which the nitrogen molecule sits. The absorption diagram in Figure $7 \mathrm{~b}$ shows several different adsorbed states prior to dissociative absorption. The $\alpha^{\prime}$ state is where the bottom $\mathrm{N}$ atom of the $\mathrm{N}_{2}$ molecule sits at the $C_{7}$ site and the top atom sits in the potential well that exists between two $C_{4}$ Fe atoms [181]. This configuration is the optimum for the nitrogen lone pair electron to interact with the surface and the surface atoms to back donate into the antibonding states of $\mathrm{N} \equiv \mathrm{N}$ thus weakening the triple bond. The next step is dissociation leading to absorbed atomic nitrogen. This model has been established from both experimental data and DFT 
calculations $[177,182]$. When there is enough atomic nitrogen on the surface, it undergoes a surface reconstruction to a cubic structure with similarities to FeN $[183,184]$.

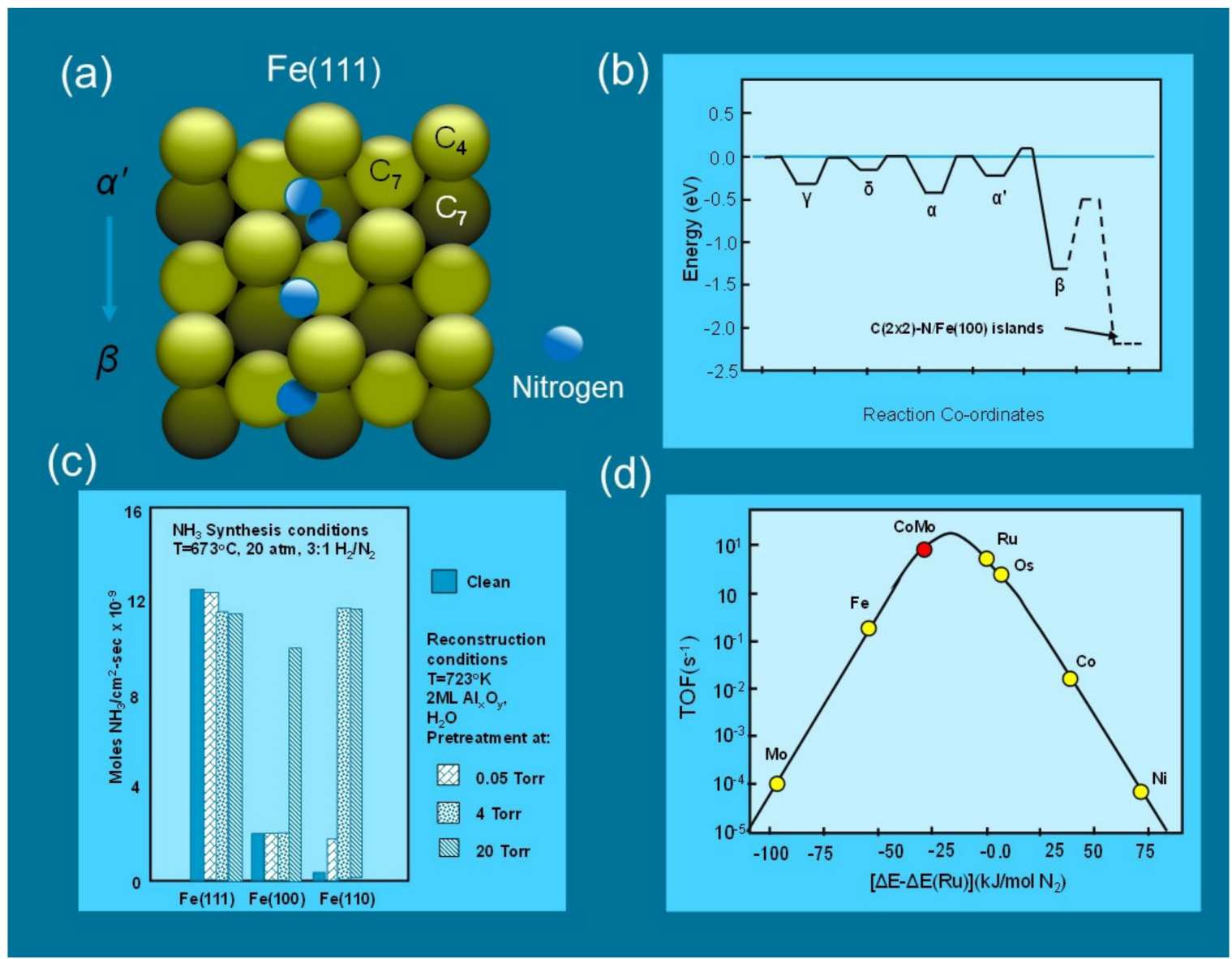

Figure 7. (a) Schematic of di-nitrogen and atomic nitrogen for two different absorption sites on Fe(111) surface based on DFT calculations $[177,182]$. On this surface, the topmost Fe atoms have four neighbours $\left(\mathrm{C}_{4}\right)$, and the surface Fe atoms on the next and following layers have seven nearest neighbours $\left(C_{7}\right)$. The $C_{7}$ site is the most active for nitrogen dissociation. (b) Energy diagram for different surface states on $\mathrm{Fe}(111)$. The $\alpha^{\prime} \rightarrow \beta$ transition is from dinitrogen to atomic nitrogen. $\mathrm{Fe}(111)$ also reconstructs into a surface nitride when there is high atomic nitrogen coverage. (c) Structure sensitivity of the Fe catalyst is demonstrated by comparing the reactivity of different Fe surface ( $\mathrm{Fe}(111), \mathrm{Fe}(100)$, and $\mathrm{Fe}(110))$. These differences can be eliminated via certain treatment as discussed in the text [185]. (d) A typical volcano curve showing the turnover frequency (TOF) for different metals as a function of the difference in $\mathrm{N}_{2}$ adsorption energy compared to Ru [186].

The catalyst used in the industrial Haber-Bosch process for the production of ammonia is, of course, not a single crystal but is formed by reduction of wustite and has structural and electronic promoters ( $\mathrm{Ca}$ and $\mathrm{Al}$ oxides as well as K and $\mathrm{Si}$ ) [187-189]. Originally, these were present in the ores used to manufacture the catalyst but may now be added to achieve desired performance. The structural promoters such as $\mathrm{CaO}, \mathrm{Al}_{2} \mathrm{O}_{3}$, and $\mathrm{SiO}_{2}$ stabilize a surface structure that has high $\mathrm{N} \equiv \mathrm{N}$ dissociation activity (presumably optimizing the number of $\mathrm{C}_{7}$ sites). The electron withdrawing properties of electropositive $\mathrm{K}$ also weakens the $\mathrm{N} \equiv \mathrm{N}$ triple bond. The activity of single crystals in the presence of some of these promoters is presented in Figure 7c. It can be seen that the reactivity of surfaces $\mathrm{Fe}(100)$ and $\mathrm{Fe}(110)$, containing $\mathrm{Al}_{\mathrm{x}} \mathrm{O}_{\mathrm{y}}$ and pre-treated in 20 Torr of $\mathrm{H}_{2} \mathrm{O}$, increases to that of $\mathrm{Fe}(111)$ in the presence of $\mathrm{Al}_{x} \mathrm{O}_{y}$ [185]. These results highlight the complexity of surface structures in heterogeneous catalysis and point to the potential complexity of finding substitutes which will have good structures for dinitrogen dissociation.

The search for alternatives for ammonia synthesis and other reactions often involves the use of volcano curves such as Figure $7 \mathrm{~d}$. These can be developed based on kinetic 
models for nitrogen dissociation over different metals (such as Figure $7 \mathrm{~d}$ or experimental data). These types of diagrams are of interest from the perspective of substitution because they show the relative activity of different metals and, in some cases, highlight why the current industry standard may be difficult to replace. In this instance, it can be seen that $\mathrm{Ru}$ has a higher turnover frequency (ToF) than Fe for ammonia synthesis. Interestingly, a CoMo binary catalyst was also predicted to perform well, and this led to significant research on Co-Mo nitrides as substitute catalysts for ammonia synthesis, which show good performance but have not been commercially adopted.

Volcano diagrams, such as in Figure 7d, indicating the higher ToF of Ru compared to $\mathrm{Fe}$, have led to the development of Ru catalysts (particularly Ru/graphite) for ammonia synthesis. Moreover, the $\mathrm{Ru}$ /graphite catalyst used in commercial ammonia synthesis has a smaller environmental footprint than the Fe-based since it operates at lower pressure and temperature. As with the Fe-based catalyst, the Ru catalyst is very structure sensitive for $\mathrm{N} \equiv \mathrm{N}$ dissociation occurring at an ensemble of $5 \mathrm{Ru}$ atoms at steps in $\mathrm{Ru}$ nanocrystallites $\left(B_{5}\right.$ site) at a rate that is $10^{9}$ times higher than a $\mathrm{Ru}(0001)$ surface (Figure 8a) $[190,191]$. The optimal structure for obtaining the highest density of these sites is on a Ru nanocrystallite with a size of around $5 \mathrm{~nm}$ in raft shaped particles, which have been grown epitaxially on hexagonal close packed structures such as that of graphite [191]. As with the Fe-based catalysts, there are structural and electronic promoters for Ru catalysts, with the most active being alkali earths $\mathrm{C}$ s and Ba. As can be seen in Figure 8b-d Cs and Ba behave differently as promoters. Cs atoms apparently sit at the interface between the Ru and the substrate (so called "hot ring" effect (Figure 8a) whereas $\mathrm{Ba}$, in the form of $\mathrm{BaO}$, decorates the surface of the Ru nanocrystallites (Figure 8b) [192]. Because of the multistep nature of ammonia synthesis from $\mathrm{N}_{2}$ and $\mathrm{H}_{2}$ (generation of atomic hydrogen and nitrogen, hydrogenation of $\mathrm{N}$ through $\mathrm{NH}^{*}, \mathrm{NH}_{2}{ }^{*}$, and $\mathrm{NH}_{3}{ }^{*}$ ) the availability of sites on the surface for reaction is key to a ToF. It should be noted that $\mathrm{Ru}$ displays a strong dissociative adsorption of $\mathrm{H}_{2}$, which can block sites not only directly for $\mathrm{N}_{2}$ adsorption but also indirectly for populating the surface with atomic nitrogen via surface diffusion after dissociation. Specifically, if the $\mathrm{B}_{5}$ sites become saturated with atomic hydrogen (hydrogen poisoning) then the activity will decrease, so it is critical to have sites available for atomic nitrogen via a surface diffusion. Hence, one role for promotion for $\mathrm{Ru}$ is to reduce the effect of hydrogen poisoning [193].

So, in the example of the Fe- and Ru-based catalysts, the end product is the same (ammonia) but the surface structures are completely different. The optimization of these sites requires control over structural and electronic promoters as well as particle size. This multidimensional problem represents a fundamental difficulty of finding substitutes for many catalytic processes. Many of the catalytic reactions based on PGMs rely on the ability of the active metal or combination of metal and support to allow for adsorption of reactants for the catalytic process to proceed. This is particularly true for auto catalysts where the high activity at relatively low temperatures of the PGM at high flow rates and short residence times is unlikely to be reproduced by other metals. The role of supports is also highlighted in auto-catalysts where alkali earth or alkali metal supports store carbonates and nitrates. This means that the prospect for substitution is not straight forward because the reactants must absorb on surface sites that have the right catalytic metals, chemistry, and structure amenable to adsorption and reaction. Indeed, the properties of PGM metals and oxides and their interactions with supports and promoters, may be unique [194]. As a final remark on substitution in ammonia synthesis, there are also homogeneous catalytic routes through the progressive hydrogenation of molecular nitrogen, but activity is very low [195].

It seems unlikely, at least in the near future, that PGMs will be replaced by other catalyst systems in many of the examples discussed above. However, in the case of auto catalysts research is being undertaken using other transition metals [111,112]. Asakura et al. [111] summarised the approaches for PGM alternatives as being (1) metal oxides supported on zeolites, spinels, or perovskites, (2) single atom or atomically dispersed metal sites as active centres, or (3) alloyed metal nanoparticles. A number of groups have 
examined highly dispersed $\mathrm{Cu}$ on a range of supports (combining paths 1 and 2) which show some good activity for NO reduction, but not at a low enough temperature [112]. Far more work has been done on binary, ternary, and quaternary mixture of $3 \mathrm{~d}$ transition metals. For example, Asakura et al. [111] have examined ternary alloys incorporating Fe into binary alloys of $\mathrm{Cu}-\mathrm{Ni}$ and found that they can perform the oxidation and reduction requirements in laboratory conditions. Hirakawa et al. [112] have examined nanoparticles comprising $3 \mathrm{~d}$ transition metal quaternary mixtures of $\mathrm{Fe}, \mathrm{Ni}$, and $\mathrm{Co}$, with $\mathrm{Cu}$. They found that an increase in the number of alloy components facilitated NO dissociation and were more resistant to oxidation than binary alloys. Despite these encouraging results, no replacement is currently available in the auto industry. There will, of course, be other types of optimization of the PGM catalyst systems with the objective of using less PGM in the TWCs. The rapidly increasing switch to EVs may mean that the search for substitutes in ICEV applications will almost certainly be wound back.

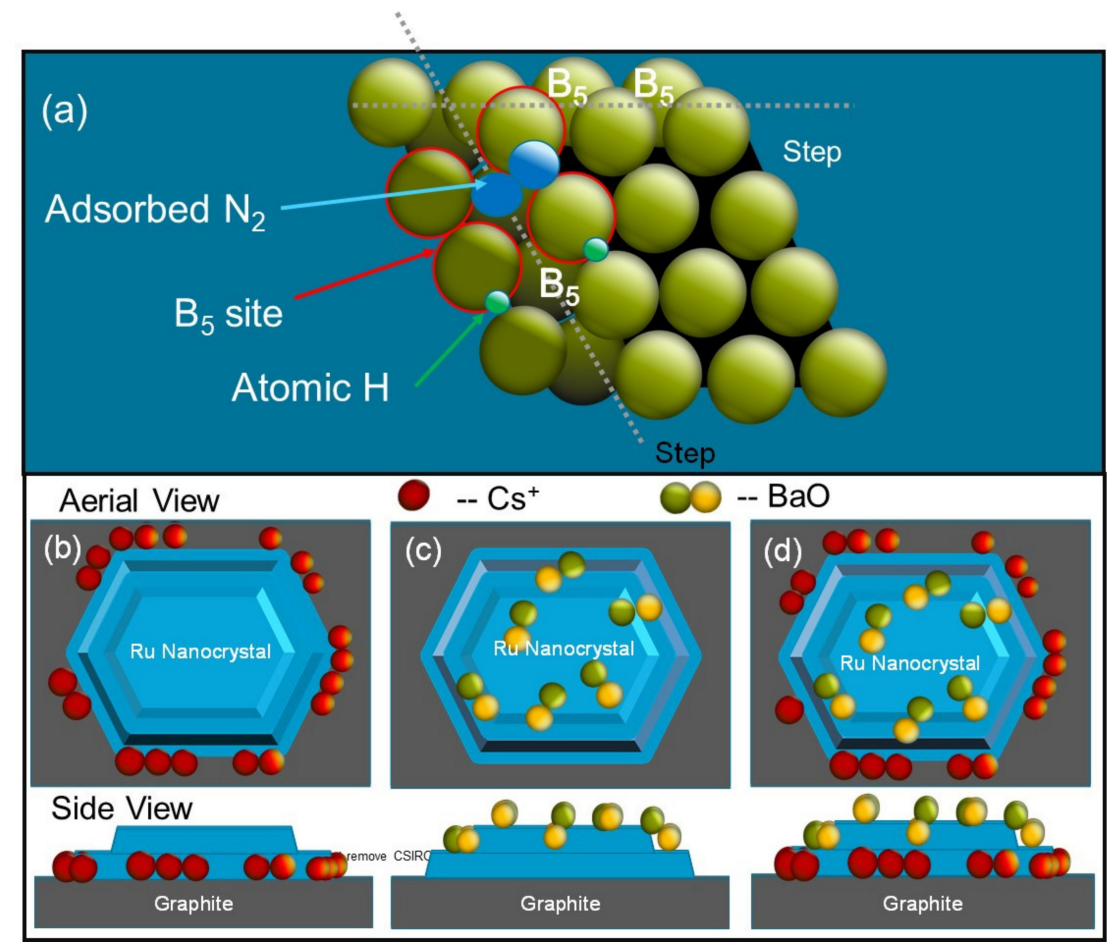

Figure 8. Dinitrogen adsorption on Ru after Hellman et al. [196] and You et al. [191]. (a) $B_{5}$ site for dinitrogen adsorption on step in Ru nanocrystal. The $\mathrm{B}_{5}$ site involves the four Ru atoms with red circumferences sitting on the top and bottom of the step plus the Ru atom directly below the step. The nitrogen molecule (blue) sits astride the step. Several other $\mathrm{B}_{5}$ sites are also indicated in (a). Two atomic hydrogen atoms are also present on the surface in green. The size of these atoms is taken from Hellman et al. [196]. (b-d) are schematics representing decoration of a Ru nanocrystalline raft decorated by Alkali earths. The structure of the Ru rafts is not explicit as the relationship between the promoters and Ru is not known precisely. (b) Caesium ion decoration around the perimeter of the $\mathrm{Ru}$ crystal, (c) $\mathrm{BaO}$ decoration on top of the Ru crystal, and (d) combined $\mathrm{Cs}$ and $\mathrm{BaO}$ decoration. Diagrams (b-d) are drafted after Kowalczyk et al. [192].

\subsection{Future PGM Demand for EVs}

PGM demand for the manufacture of EVs is difficult to predict with certainty for two reasons. First, the actual demand for EVs, even though it is increasing, is uncertain [168]. Clearly, previous projections for the numbers of EVs have over-estimated what has eventuated. The prediction of total EV car numbers are further complicated by the uptake of smaller two and three wheel EVs, which compete in the same market [197]. Second, the quantity of PGMs used in different types of EVs can vary by two orders of magnitude 
depending on EV types (see Section 4.3.2). One big source of variation will be the loading of PGM containing electrode catalysts in FCEVs [75,174].

Figure 9a,b shows the amount of $\mathrm{Pt}$ in vehicle stock and the projected $\mathrm{Pt}$ demand for scenarios defined by the IEA, respectively [197]. The scenarios include the "Stated Policies" scenario which outlines EV uptake based on legislated or announced government policies from around the world. The "sustainable development" policy aims for universal access to energy, reduction in pollution, and reduction in greenhouse gas emission, according to the Paris Agreement. The 2025 figures for the sustainable development scenario are not included in Figure 9. For BEVs and PHEVs, it has been assumed that Pt is only in the electronics and sensors, so a figure of $0.1 \mathrm{~g} /$ vehicle has been used, whereas for fuel cell vehicles, additional $\mathrm{Pt}$ is used in the cell electrodes, and a figure of $12.3 \mathrm{~g} /$ vehicle is used (see Section 4.3.2). In terms of the accumulation of Pt in vehicle stock, it is not too surprising to see that cars with fuel cells make the biggest contribution. This contribution is around $60 \%$ for a little under 5 million vehicles, whereas BEV and PHEV cars constitute around $20 \% \mathrm{Pt}$ for around 200 million vehicles. Clearly FCEVs will have the biggest impact of Pt flows.

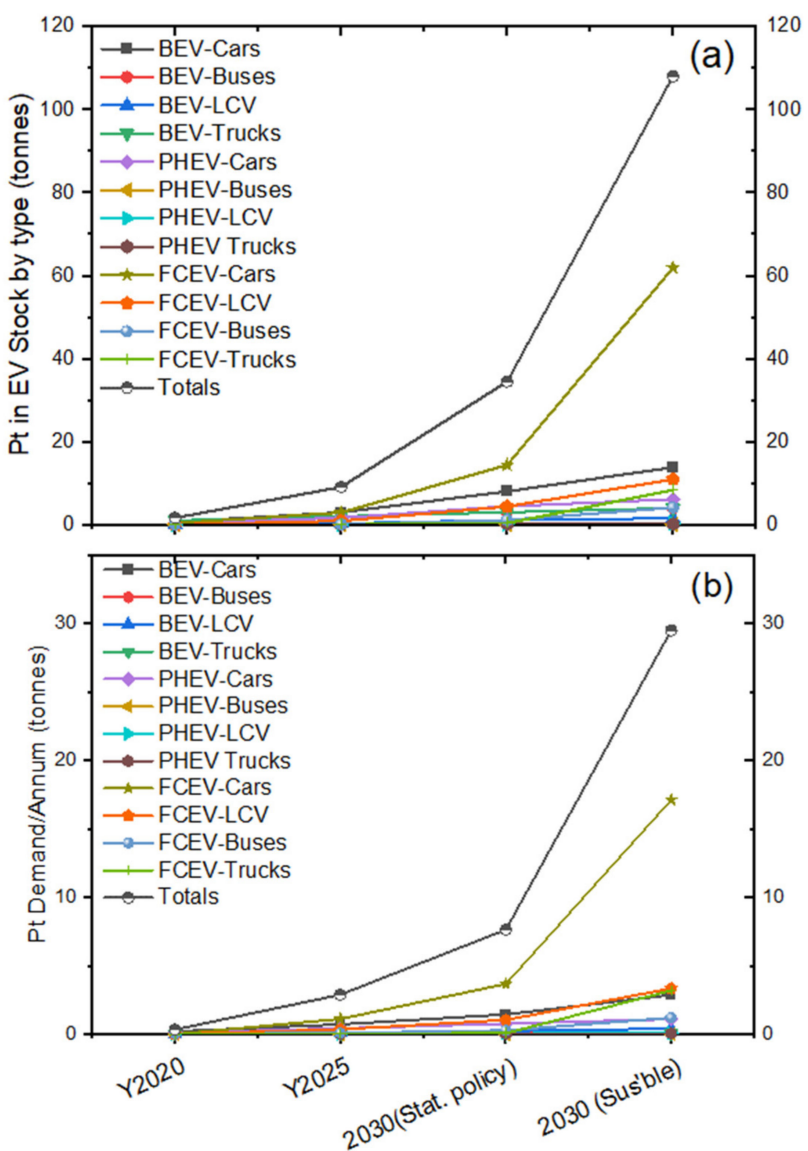

Figure 9. Predicted Amount of Pt required in BEVs, FC EVs, and Hybrids (PHEVs) under different scenarios, as defined in the latest IEA report on EVs. Scenarios include the year 2019, 2025, 2030, and a "highly sustainable" scenario for 2030. Based on figures obtained from: [197] Global EV Data Explorer-Analysis-IEA. (a) Amount of Pt in a vehicle stocks up to the designated year and (b) Pt demand/annum for the EV market. Both the stock and demand figures are broken down into EV types and vehicle types. It is assumed that BEV and PHEV have a Pt demand associated with sensors and auto electrics, but FCEVs have Pt demand for catalysts for the fuel cell. The figure used is $12.3 \mathrm{~g}$ /vehicle taken from Hou et al. [45]. (Stat. Policy-current combined stated policies of all nations and pertains to Y2025 and Y2030 (Stat. Policy) and "Sus'ble" is sustainable development policy (see text for details)). 
A similar trend can be seen in the projected annual Pt demand for different types of vehicles in the 2030 "sustainable development" scenario. FCEV-cars have the highest Pt demand at around $60 \%$ of total demand required for 1.3 million cars, whereas BEV and PHEV cars have only $13 \%$ of demand for the manufacture of approximately 40 million cars. The total Pt demand of around $30 \mathrm{t} /$ annum for the "sustainable development" scenario (Table 6) is well below current total demand from the auto sector, as well as the projected demand for a scenario where there are no EVs in the fleet (Table 6, orange column). When future projected ICEV annual Pt demand (Table 6, central green column) is added to the EV demand, then the total Pt demand approaches the demand without EVs but does show a reduction compared to an ICEV fleet (Table 6, far right green column compared to yellow column). It should be noted that these figures are calculated using a realistic figure of $12.5 \mathrm{~g} / v$ for FCEVs $(\sim 0.125 \mathrm{~g} / \mathrm{kW})$. Interestingly, despite the large increase in the percentage of the market under the different EV uptake scenarios, the projected Pt demand is similar.

Table 6. Projected Pt Demand for various 2030 IEA scenarios assuming production of 120,000,000 vehicle in 2030 (Colour: yellow for pure demand for ICEVs and green mixed demand for EVs and ICEVs).

\begin{tabular}{cccccc}
\hline Scenario & $\begin{array}{c}\text { \% of } \\
\text { Market }\end{array}$ & $\begin{array}{c}\text { ICEV Demand } \\
\text { Without EV } \\
\text { (Tonnes) }\end{array}$ & $\begin{array}{c}\text { EV } \\
\text { Demand } \\
\text { (tonnes) }^{\mathbf{2}}\end{array}$ & $\begin{array}{c}\text { ICEV } \\
\text { Demand } \\
\text { (Tonnes) }^{\mathbf{3}}\end{array}$ & $\begin{array}{c}\text { Total Pt } \\
\text { Demand } \\
\text { (EV + ICEV) }\end{array}$ \\
\hline $\begin{array}{c}\text { Stated } \\
\text { Policies }\end{array}$ & 17.3 & 134.3 & 7.6 & 110.8 & 118.4 \\
\hline $\begin{array}{l}\text { Sustainable } \\
\text { Development }\end{array}$ & 36 & 134.3 & 29.5 & 85.9 & 115.4 \\
\hline
\end{tabular}

${ }^{1}$ Based on 2030 projected vehicle numbers ( 120,000,000) and Pt demand for auto catalysts (89.5 tonnes) per vehicle in $2019(80,000,000)$ which equates to $1.1 \mathrm{~g} /$ vehicle. (Note that other PGMs included in addition to Pt in ICE vehicles). ${ }^{2}$ Based on $0.1 \mathrm{~g} /$ vehicle for EVs apart from FCEV which were $12.5 \mathrm{~g} /$ vehicle. Vehicle numbers from IEA. ${ }^{3}$ Numbers adjusted based on EV market share; Pt g/vehicle based on the same value as for footnote 1.

Looking more closely at Pt demand for FCEVs, Figure 10 shows the annual demand under a range of scenarios as well as different levels of penetration of FCEVs into the EV market. First, we examine the IEA Sustainable development scenarios of $2.8 \%$ penetration of the EV market for a mix of different Pt "loadings" per vehicle. The high demand scenario includes $35 \mathrm{~g} / \mathrm{v}$ for cars and vans and $25 \mathrm{~g} / \mathrm{v}$ for trucks and buses, with a total annual demand in 2030 of 66 tonnes under the IEA scenarios. The figures of $35 \mathrm{~g} / \mathrm{v}$ and $25 \mathrm{~g} / \mathrm{v}$ were taken from Banham et al. [75] and represent the upper end of loadings for current technology. Values higher than this have been reported but are not considered feasible from a commercial perspective $[162,198]$. The "medium" scenario uses a realistic current value for cars and vans $(22.5 \mathrm{~g} / \mathrm{v})$, reported by Kongkanand and Mathias [176], and the Banham et al. figure for buses and trucks. The "low" scenario starts to get into target values. In this scenario, a value of 12.5, taken from Hou et al. [45], is used for everything; this value is approximately equivalent to $0.125 \mathrm{~g} / \mathrm{kW}$. Finally, the "target" scenario uses the "stretch" target [176] of $6 \mathrm{~g} / \mathrm{v}(0.0625 \mathrm{~g} / \mathrm{kW})$ for cars and $12.5 \mathrm{~g} / \mathrm{v}$ for buses and trucks. Of course, any number of combinations can be calculated using different mixes of catalyst loading, but the following general points can be made here. Under the IEA scenarios for FCEVs in 2030, the FCEV Pt demand, as well as the total demand for the complete EV+ICEV fleet, will still be below total demand from a 100\% ICEV fleet (Table 6, 134.3 tonnes). Realistic projections for likely Pt demand probably lie somewhere between the "low" and "medium" scenarios listed below, as these figures reflect the current status of the technology. One complication of the catalyst loadings associated with stretch targets noted by several authors is that performance starts to drop off significantly at high current density $\left(>1 \mathrm{Acm}^{-2}\right)$, indicating a lower bound on the level of Pt loading [176], although catalyst design for lower loadings is an active area of research, as reviewed by Banham et al. [75]. 


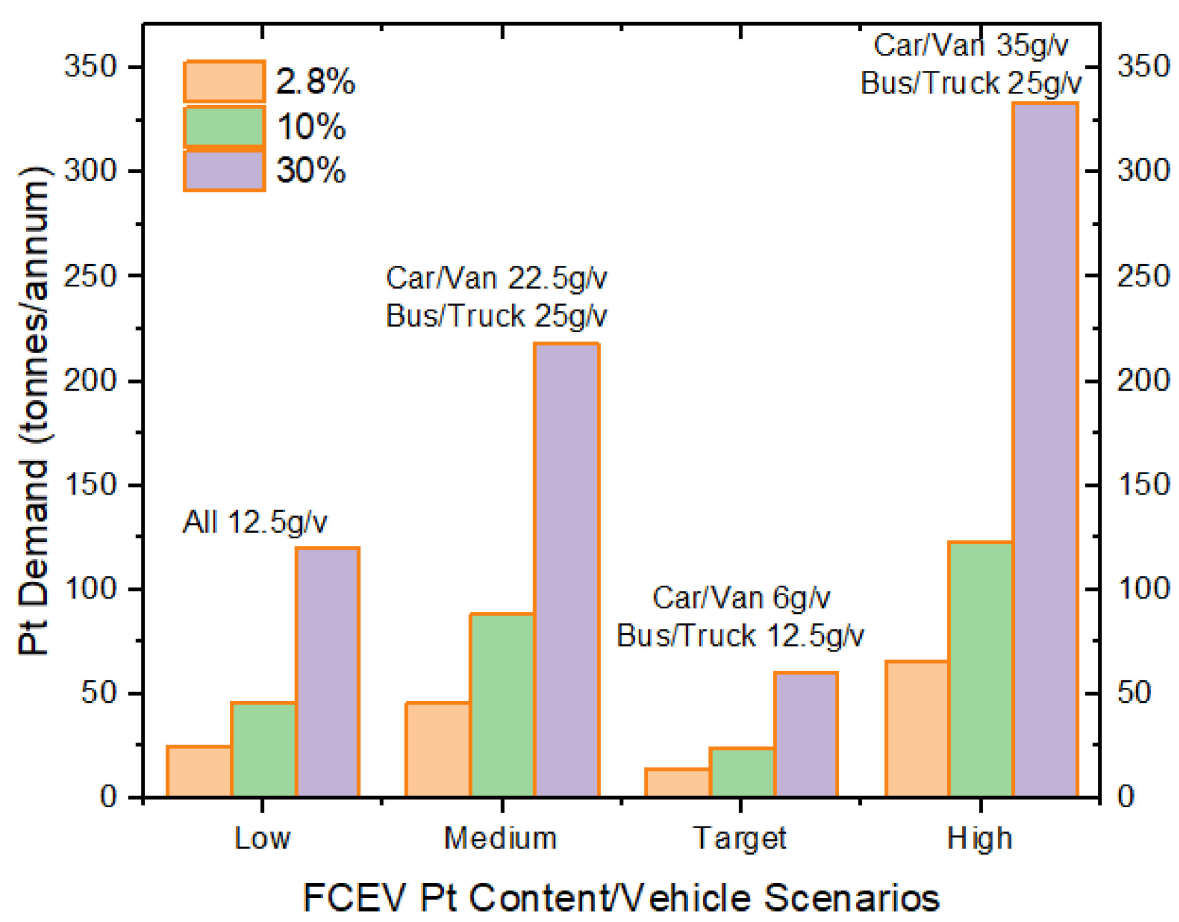

Figure 10. Pt Demand from FCEV sector using gram/vehicle $(g / v)$ loadings from a number of different sources. The vehicle scenario is the sustainable development 2030 IEA scenario. This scenario has FECV cars as 2.8\% (Orange) of the total EV fleet consisting of 1,368,831 cars, 267,260 Light Commercial Vehicles (Vans), 96,109 Buses, and 254,858 Trucks. The number of grams/vehicle $(g / v)$ are enumerated in the figure, which also shows the mix. Included are scenarios where FECV make up $10 \%$ (green) and 30\% (mauve) of the total EV-car category. Numbers are obtained by adjusting the BEV numbers downward and making a corresponding increase in the FCEV, with no change to PHEV numbers.

It should be pointed out that in the IEA "sustainable" scenario, FCEVs only constitute around $2.8 \%$ of the total car market, if this percentage increased significantly, then the $\mathrm{Pt}$ demand would increase significantly. Beyond the IEA sustainable development scenario, there could be different levels of penetration of FCEVs into the total EV market which could have implications for Pt demand. In Figure 10, two additional levels of penetration of FCEVs are presented, both of these scenarios only use substitution of FCEVs for BEVs in the total EV market. At $10 \%$ substitution, Pt demand increases with only the "high" loading scenario at 123 tonnes/annum actually exceeding 100 tonnes. With $30 \%$ penetration, all scenarios apart from the target scenario exceed 100 tonnes/annum with the "highest" loadings category reaching 334 tonnes/annum. Only the, as yet to be achieved, "target" loading at 60 tonnes/annum is a realistically manageable Pt demand without substantial price increases and commensurate with current Pt demand for autocatalysts of 70 to 80 tonnes/annum (Figure 1). These different Pt demands for different levels of penetration of FCEVs into the EV market suggest that there may be serious limitations for larger scale FCEVs uptake in the auto market and indicate that a policy framework might be necessary for use of $\mathrm{Pt}$ in these types of applications.

\section{Recycling/Secondary Supply}

Data is not available for recycling for all PGMs, but there is data for $\mathrm{Pt}, \mathrm{Pd}$, and $\mathrm{Rh}$ in the literature. Many aspects on recycling of critical metals have been published $[38,166,199]$. $\mathrm{Pt}$ and Pd obtained via recycling each constitute around 20-25\% of the total market [25]. Sources of scrap PGMs include spent catalysts, electronic scrap, jewellery manufacturing scrap (new scrap), and scrap from other applications, such as extrusion dies and crucibles, used in glass manufacture and other areas, as discussed below. In digital technology, hard 
disk recycling has not yet peaked [25], and mobile phone recycling is also still immature [72], indicating that increased recovery from these sources may be possible in the future. For vehicles, there are emerging assessments of the value of the cyclic economy, but price of the PGMs will play a critical role [134,200]. Some analysis of recycling of Pd and Pt from PCBs and oxygen sensors in vehicles has also been performed [134].

For some of these sources, Hagelüken [201] suggests the following PGM content: computer boards $80 \mathrm{~g} / \mathrm{t} \mathrm{Pd}$, mobile phones $130 \mathrm{~g} / \mathrm{t} \mathrm{Pd}$, and auto-catalysts $2000 \mathrm{~g} / \mathrm{t}$ PGM which are all better than a nominal value of $<10 \mathrm{~g} / \mathrm{t}$ for primary ores. Bahaloo-Horeh suggests there might be nearly $5000 \mathrm{~g} / \mathrm{t}$ of PGM in auto-catalyst [202]. Presumably, these differences relate to variation among auto manufacturers, regulatory environment changing with time, and geographical location.

In principle, the recycling route for PGMs in certain sectors, e.g., in auto or industrial catalysts or electronics, should be well defined because the PGM content of the product is relatively well known and its matrix well defined, and in some areas, recycling is already well established $[70,203,204]$. Indeed, Hagelüken suggests that it should be possible to collect over $90 \%$ of PGM [201]. The total number of vehicles manufactured is also well known. For example, the number of cars manufactured worldwide in 2018 was 70,470,000 which is down from $72,110,000$ in 2016. An additional 21,070,000 commercial vehicles were also manufactured. The total vehicle stock in 2015 was 1.1 billion, and there were 377 million trucks [205].

However, PGM recycling from auto-catalysts has a number of drivers that makes predicting the level of PGM recovery difficult [166,201]. Recycling of PGMs is not solely driven by the price of the PGMs per se, but it also depends on the catalyst loading of PGM and this has changed with changing emission regulation particularly $\mathrm{NO}_{x}$ emission as described above $[25,106,138]$. The amount of material recycled from auto-catalysts is further complicated by lengthening of vehicle lifetimes, which has introduced a "lag" in the recycling cycle. Export of second hand vehicles into regions where there is less recycling also complicates the recovery of PGMs [25]. Furthermore, there appear to be unidentified "sinks" for vehicle recovery. For example, in 1998, the USGS reported that around $17,000,000$ vehicles were scrapped, but only 12,000,000 were recycled. Whether the remaining 5,000,000 were stockpiled or lost to the cycle was unclear, leaving nearly $30 \%$ unaccounted. A similar level of recovery has been reported for Europe [166]. Further complicating the drive for recycling, as can be seen from Figure 4, is that for any particular year there will be a mix of different technologies in the "fleet" of retired vehicles and therefore, different PGM levels. Thus, the proposition for overall profitability of recycling PGMs from auto-catalysts will depend on the total PGM present in individual vehicle types and year of manufacture, which may be difficult to determine due to differences in average vehicle lifetimes.

Nevertheless, the largest contribution to recycling is from auto-catalysts. For example, in 2014, over $80 \%$ of PGM recovery was from auto-catalysts (103 tonnes of 123 tonnes) in the USA [7]. There was 50-60\% recovered in Europe in 2012 [201]. However, secondary PGM recovery from auto-catalysts only appears to currently constitute around 35-45\% of auto-catalyst demand, as can be seen in Figure 11, where data is presented, for the amount of PGM recovered, as a percentage of the PGM demand for auto-catalysts for that year. Similar figures are quoted for the European situation [166]. Of course, there is a lag time between catalyst manufacture and recycling, which Johnson Matthey reports suggest might be between 12 to 13 years, rising to between 13 and 18 years in November 2016 [139]. Since the Pt and Rh demands for auto-catalysts have not changed much over a long period, the $\mathrm{Pt}$ and $\mathrm{Rh}$ figures are probably a reasonable reflection of their level of recycling from auto-catalysts. Pd demand, however, has increased markedly in auto-catalysts, so the level of recycling will be lower, as can be seen in Figure 11, i.e., current demand is higher than $\mathrm{Pd}$ content of the recycled catalyst, which may be over a decade old. If, however, the Pd data is adjusted by dividing the Pd demand at the time of catalyst manufacture (value from 1998 is taken here) then, with a 12 year lag time between start-of-life and end-of-life, a more 
realistic estimate of the level of Pd recycling is obtained. This is confirmed in Figure 11, where the \% Pd recycled reaches the same value as the Pt and Rh after correction. Globally, these figures indicate a much lower level of auto-catalyst recycling than is achieved in the USA.

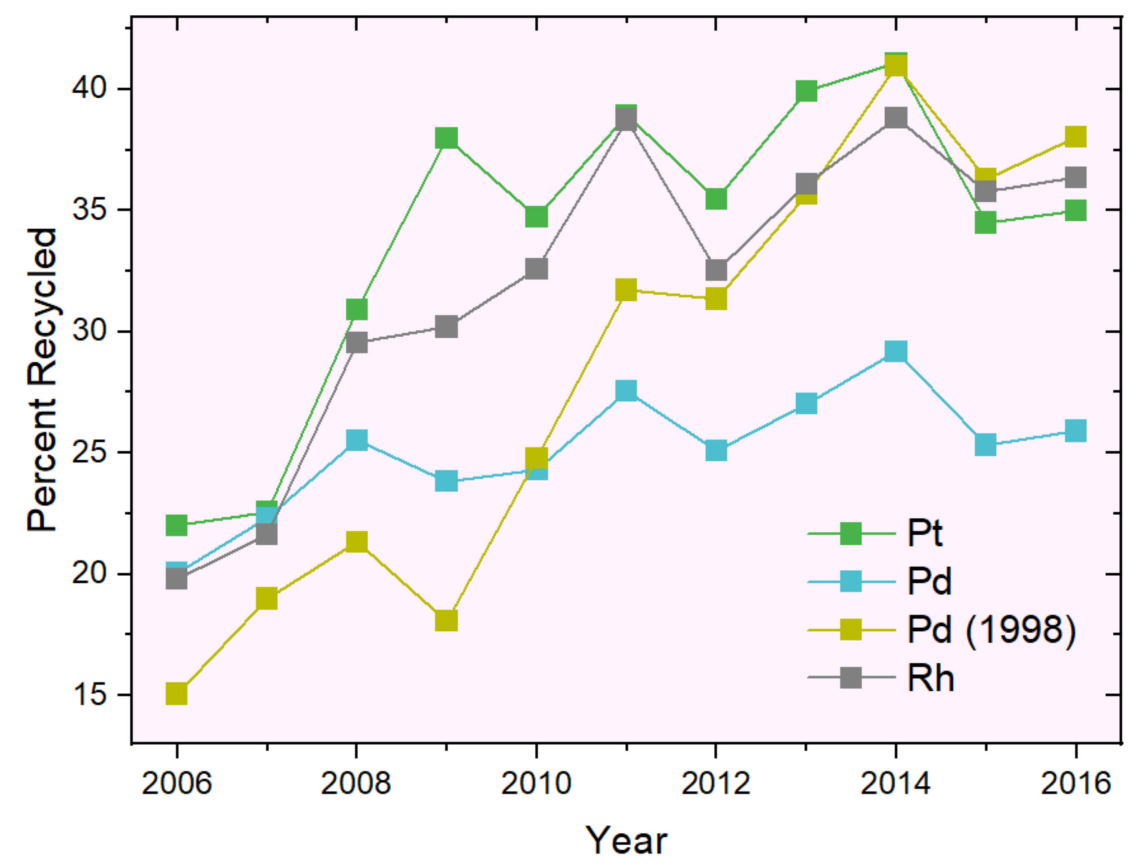

Figure 11. PGM recycling for the auto industry. Data is presented as the percent PGM sourced from autocatalysts divided by the demand for the same year. The Pd (1998) data provides the percent sourced from autocatalysts for a particular year divided by the 1998 demand of Pd (see text for explanation).

Figure 12 shows scanning electron microscopy characterization results for a honeycomb monolith and catalyst washcoat published by Trinh et al. [206]. The two top images are backscattered electron images where brightness highlights the distribution of heavier atomic number material (PGM and cerium oxide (ceria)). The recycling challenge is to remove the monolith materials, thus enriching the residue with PGM and ceria, which can be further treated. According to USGS, auto catalyst recycling may be via a number of processes including (i) dissolution in aqua regia (literally "kingly water" because it dissolves gold and platinum; 1 part $\mathrm{HNO}_{3}$ to 3 to 4 parts $\mathrm{HCl}$ [207]) to produce PGM chlorocomplexes which are further refined by reduction, (ii) gas phase processing via volatilization, or (iii) blending with PGM refined ores for further processing. For the purposes of enrichment, processing using base $(\mathrm{NaOH})$ should also be added to this list. Further processing includes standard mineral processing approaches of hydrometallurgy, pyrometallurgy followed by, most likely, by solvent extraction or ion exchange $[93,206]$. It should be noted that this is a busy area of research with many hundreds of patents already published this century [201]. In industrial catalysis, recycling is more effective, with catalyst manufacturers often reprocessing their own spent catalysts at end-of-life. In a sense, recovery from recycling represents the same proposition as in mining, where the PGMs are treated as co-products or even by-products of auto recycling where profitable materials e.g., steel or aluminium recovery, are the prime target [25]. For reforming catalysts, recovery is around $99.8 \%$ and undertaken under strict accounting procedures. Recycling is usually performed using dissolution of the alumina support in sulfuric acid; the PGMs are not soluble under the operating conditions of the process so a PGM-rich precipitate forms, which can be collected. 
a)

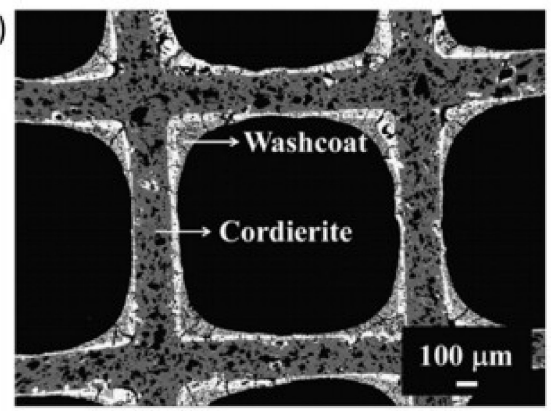

c)

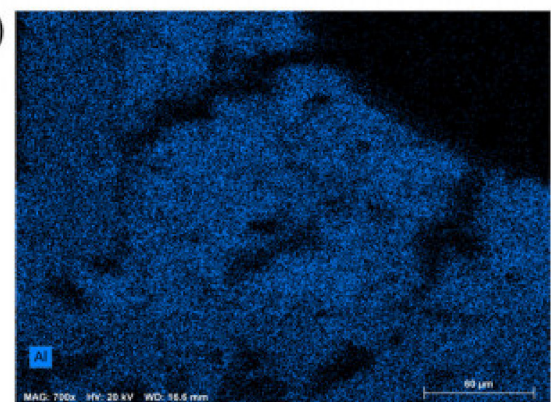

e)

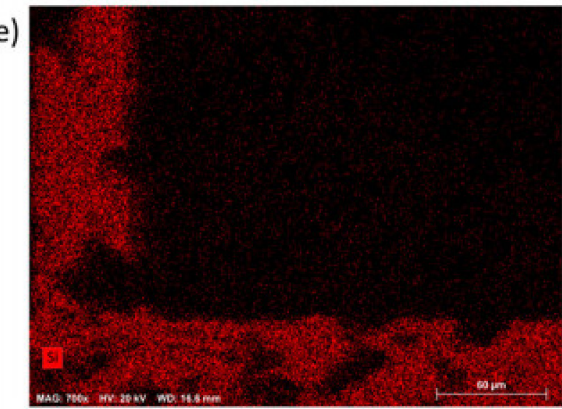

b)

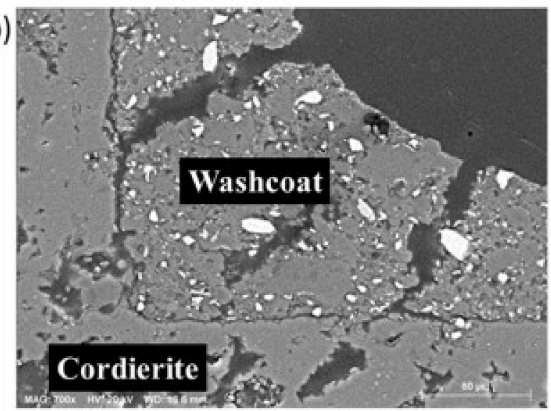

d)

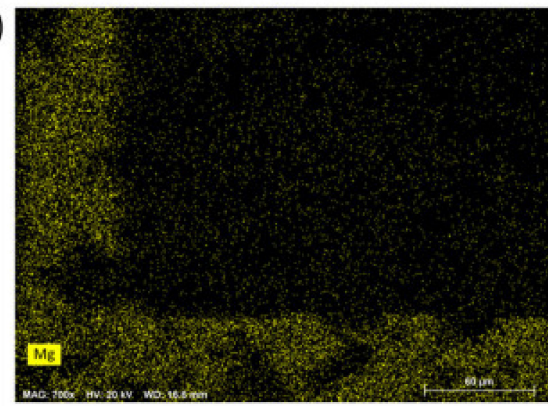

f)

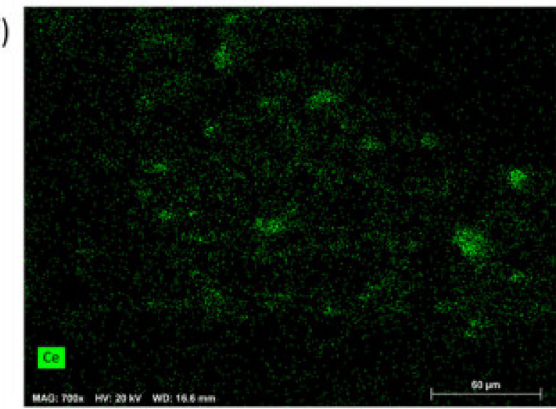

Figure 12. (a,b) Backscattered images of an autocatalyst monolith, washcoat and various EDS maps including (c)Al, (d) Mg, (e) Si and (f) Ce. The heterogeneity of the washcoat can be seen in the Al and Ce maps by comparison with the SEM images ((b-f) Scale bars are $60 \mu \mathrm{m})$. After Trinh et al. [206] (reproduced with permission).

Overall Trinh et al. [206], in an excellent review, suggest that large scale recycling using pyrometallurgy might be better suited to large operations, whereas smaller scale might be better suited to hydrometallurgy. This is because of the big environmental footprint for pyrometallurgical processes which, presumably, can be better controlled in a large scale plant (e.g., by better use of waste heat). Research into lowering the environmental footprint by lowering the temperature in the pyrometallurgical processing step is also being investigated [208].

Recycling of catalysts from FCEVs has some differences to ICEVs. One major difference is that the fuel cell stack is reported to be generally easier to remove than catalytic converters, but handling can lead to incidental loss of PGM as it does with catalytic converters on an ICEV system [162]. Disassembly of the fuel cell stack is also problematic [162]. PEMFC use Nafion ${ }^{\circledR}$ as the membrane $[162,172,204,209]$, and normal hydrometallurgical processing of this material can result in the release of HF, which is a toxic chemical representing a challenges which Wittstock et al. have discussed [162]. The most recent research explores a number of methods for recycling of PEMFCs including ultrasonics [210] and hydrometallurgical processes including in $\mathrm{HCl} / \mathrm{H}_{2} \mathrm{O}_{2}$ [209,211]. Ideally, extraction of the catalyst coated membrane is desired, but current processes target complete disassembly [210]. Ironically, the drive to lower Pt content/vehicle and the lower load of electrode catalysts means that the value proposition is lowered for recycling. Thus, we are confronted with the paradox that more efficient FECVs may lead to greater Pt dissipation. 


\section{Dissipation}

The main source of PGM dissipation is the automotive catalysts which, for example, accounts for 50\% of emissions in Europe in 2014 [212]. The catalyst itself undergoes mechanical degradation as a result of sintering and thermal shock which releases washcoat particulate matter (Figure 12) [213]. This means that PGMs are released into the environment on roadsides, such as freeways and highways, where they may eventually be carried into waterways and the ocean where they are effectively lost [213-216]. The accumulation of $\mathrm{Pt}$ and $\mathrm{Pd}$ on road verges has been measured in a number of studies, in a number of countries, and indicates that this dissipation source is a worldwide issue. It is assumed that PGMs dissipated via mine sites are not included in any inventory of PGM dissipation, although data exists in national and regional pollutant inventories that would support incorporation of mine site dissipation into global assessments of PGM dissipation. The use of mainly Pt in EVs, in principle, should result in less dissipation of Pt because operating temperatures of fuel cells in FCEVs are lower than the exhaust catalysts used in ICEVs, so there is less thermal impact damage. However, as always, the capture of Pt will depend on the economic drive to recover $\mathrm{Pt}$ from waste vehicles. One can imagine that, for two and three-wheeler vehicles, where the Pt load is only associated with the electrics and electronics, the potential for dissipation is high. For larger vehicles (cars, vans, buses, and trucks) the economic proposition is better and should be best for FCEVs. Clearly, if PGM recovery from ICEVs where there is around $6 \mathrm{~g} /$ vehicle of PGM is problematic, then recovery of Pt from EVs other than FCEVs will probably lead to dissipation in the absence of a legislative driver for PGM recovery.

The loss of PGM to the environment not only has a negative impact on supply, but it also has other implications for the biosphere [217]. There have been numerous studies on the uptake of PGMs into plants, animals, and the food chain $[212,217]$. While the release of metallic PGMs into the environment may not be considered particularly harmful because of their low toxicity, there are routes to bioavailability through platino-chloro complexes and amino-platino-nitrates [218]. Airborne auto catalysts particulates [213] deposited in rats lungs, rather than being inert, were apparently dissolved to some extent because they were present in blood and other organs [219], indicating that ingestion via the lungs was possible. Moreover, given that humans have one of the lowest stomach $\mathrm{pHs}(\mathrm{HCl})$, the potential for ingestion via this route might be considerably higher than other mammals or birds [220]. It is known that $\mathrm{Pt}$ in higher oxidation states (e.g., $\mathrm{Pt}(\mathrm{II})$ and $\mathrm{Pt}(\mathrm{IV})$ ) inhibits cell division, hence its use in cancer treatments. The long-term implication of higher $\mathrm{Pt}$ and PGM levels in the environment is unknown. While not strictly dispersion from a recognized source, PGMs are also present in dust from cement manufacture [221].

\section{Conclusions}

In this paper, the abundance, mineralogy, supply, applications, recycling, and prospects for substitution of PGMs have been reviewed. The greatest demand for PGMs is for autocatalyst applications followed by the industrial sector, which includes industrial catalytic processes where PGMs are used. It is expected that the industrial sector will not experience much change in the immediate future since it is a mature sector and procedures and practices for PGM use and recycling are well established. In the ICEV area, the impending changeover to EVs is likely to result in little auto catalyst development for this application in the longer term. On the other hand, the prospective use of PGMs in electrode catalysts in batteries and the uptake of FCEVs will result in increased demand principally for $\mathrm{Pt}$, perhaps beyond the current demand from the auto sector. There will be a strong drive to meet, or exceed, the US DOE target of $0.125 \mathrm{~g} / \mathrm{kW}$. Prospects for substitution of PGMs, by other elements in catalytic processes, in general, is not so straight forward. In some cases, processes containing PGMs are the end point of a long evolution process to improve catalytic activity and selectivity. For example, auto-catalysis is one such area where the PGMs offer much better activities at lower temperature and higher exhaust flowrates than other options (this applies both to ICEVs as well as EVs). Auto-catalysis in ICEVs, however, 
is one of the most dissipative applications for PGMs since the catalyst supports degrade over time, resulting in emission through the vehicle exhaust system and loss into the environment. A switch to BEVs might also lead to lower dissipation for auto catalysts because of lower operating temperatures and, perhaps, increase the recyclability. The current rates of recovery of PGMs in industrial processes is generally good. However, there is a need to improve recovery of PGMs in the auto industry. The known reserves of the PGMs suggest lifetimes between 100 and 200 years, indicating no immediate threat to supply.

Author Contributions: A.E.H., N.H. and S.A.N. reviewed the background literature on PGM mining and production. A.E.H. and S.G. reviewed the uses of PGM and focused on the catalytic applications for auto and other applications. All authors have read and agreed to the published version of the manuscript.

Funding: This paper received no external funding.

Institutional Review Board Statement: Not applicable.

Data Availability Statement: Not applicable.

Acknowledgments: The authors thank their respective employing organisations (CSIRO and University of Technology Sydney) for allowing them to write this manuscript. There is no funding received for covering the costs to publish in open access journal.

Conflicts of Interest: The authors declare no conflict of interest.

\begin{abstract}
Abbreviations
AC: Alternating current, AFC: Alkaline fuel cells; A/F: Air to fuel ratio, BEVs: Battery electric vehicles; DC: Direct current, DFT: Density functional theory; DOC: diesel oxidation catalyst, DPF: Diesel particulate filter; DMFC: Direct methanol fuel cells; EVs: Electric vehicles; EVI: Electric Vehicle Initiative; FCEVs: Fuel cell electric vehicles; GFC: Global financial crisis; ICEVs: Internal combustion engine vehicles; IEA: International energy association; IPHE: International Partnership for Hydrogen and Fuel Cells in the Economy; LNT: Lean $\mathrm{NO}_{\mathrm{x}}$ trap; MCFC: Molten carbonate fuel cells; MLCC: Multilayer ceramic capacitor; OLEDs: Organic light emitting diodes; ORR: Oxygen reduction reaction, PAFC: Phosphoric acid fuel cell, PEM: Polymer electrolyte membrane, PEMFC: Polymer eletrolyte membrane fuel cell, PET: Polyethylene terephthalate; PGMs: Platinum group metals; PHEV: Plugin hybrid electric vehicles, PM: Particulate material, RFC: Reversible fuel cells; RoW: Rest of the world; SCR: Selective catalytic reduction; SEM: Scanning electron microscopy, SOFC: Solid oxide fuel cell, ToF: Turnover frequency; TWC: Three-way catalyst; USA: United States of America, USGS: US Geological Survey, VOC: Volatile organic chemical.
\end{abstract}

\title{
Appendix A
}

The reserves of the each PGM and total PGMs were determined in the following manner: There are a number of sources for PGM content of ores bodies, which have also been presented in Table 2 [14]. The data of Hagelüken [14] (" $\left.\mathrm{H}^{\prime \prime}\right)$ and Mudd et al. ("M") are both presented for the South African ore bodies. The data from Mudd et al. [8] provides more recent, detailed data for different parts of the ore bodies. In determining the level of resource for each PGM and only using the Hagelüken data, the ore body data for each of the South African and Canadian bodies were first averaged:

$\bar{X}_{n}^{i}=\frac{1}{m} \sum_{j=1}^{m} X_{j}^{i}$ (where $m$ is the number of assays and $i$ is an index representing each PGM)

Then the tonnage for each country $\left(T_{n}\right)$ is determined using the total PGM reserve $\left(R_{n}\right)$ values for each country (in this case USGS 2017 values) and multiplying by the fraction of each element $(i)$ of the total PGM in $\mathrm{g} / \mathrm{T}\left(X^{\text {tot }}\right)$ :

$$
T_{n}^{i}=\bar{X}_{n}^{i} R_{n} / \bar{X}_{n}^{t o t}
$$


This provides a list of total PGMs by country which are presented in the right hand column of Table 2. The sum of these PGM reserves is 66,510 tonnes, close to the 66,000 tonnes USGS value. The reserves for individual PGMs are provided in the second to bottom row. The most recent USGS figure for the world reserves for PGMs is 69,000 metric tonnes (Note that this figure is lower than the resource values reported by the USGS [7] and Mudd et al. [8] but both of these include $\mathrm{Au}$ ).

\section{References}

1. Hilliard, H.E. Platinum Recycling in the United States in 1998; U.S. Geological Survey: Reston, VA, USA, 2001.

2. Suess, H.E. Abundances of the elements. Rev. Mod. Phys. 1956, 28, 53-73. [CrossRef]

3. USGS Platinum-Group Metals Statistics and Information, Minerals Commodity Summary for 2020; U.S. Geological Survey: Reston, VA, USA. Available online: https:/ / www.usgs.gov/centers/nmic/platinum-group-metals-statistics-and-information. (accessed on 16 March 2021).

4. Mudd, G.M. Key trends in the resource sustainability of platinum group elements. Ore Geol. Rev. 2012, 46, 106-117. [CrossRef]

5. Starostin, V.I.; Izbekov, E.D.; Razin, L.V.; Sakya, D.R. Perspectives of the discovery of large and unique noble metal deposits in the northeastern Siberian Platform. Mosc. Univ. Geol. Bull. 2016, 71, 252-261. [CrossRef]

6. Nassar, N.T. Limitations to elemental substitution as exemplified by the platinum-group metals. Green Chem. 2015, 17, 2226-2235. [CrossRef]

7. Zientek, M.L.; Loferski, P.J.; Parks, H.L.; Schulte, R.F.; Seal, R.R., II. Platinum-Group Metals; U.S. Geological Survey: Reston, VA, USA, 2017.

8. Mudd, G.M.; Jowitt, S.M.; Werner, T.T. Global platinum group element resources, reserves and mining-A critical assessment. Sci. Total Environ. 2018, 622-623, 614-625. [CrossRef] [PubMed]

9. Cawthorn, R.G. The Platinum Group Element Deposits of the Bushveld Complex in South Africa. Platin. Met. Rev. 2010, 54, 205-215. [CrossRef]

10. Oberthür, T.; Melcher, F.; Buchholz, P.; Locmelis, M. The oxidized ores of the Main Sulphide Zone, Great Dyke, Zimbabwe: Turning resources into minable reserves-mineralogy is the key. J. South. Afr. Inst. Min. Metall. 2013, 113, $191-201$.

11. Haque, N.; Hughes, A.; Lim, S.; Vernon, C. Rare Earth Elements: Overview of Mining, Mineralogy, Uses, Sustainability and Environmental Impact. Resources 2014, 3, 614-635. [CrossRef]

12. Emsley, J. Ruthenium. In Nature's Building Blocks: An A-Z Guide to the Elements; Oxford University Press: Oxford, UK, 2003; pp. 368-370.

13. Weng, Z.; Jowitt, S.M.; Mudd, G.M.; Haque, N. A detailed assessment of global rare earth element resources: Opportunities and challenges. Econ. Geol. 2015, 110, 1925-1952. [CrossRef]

14. Hagelüken, C. Markets for the catalyst metals platinum, palladium and rhodium. Metall 2006, 60, 31-42.

15. Grandell, L.; Lehtilä, A.; Kivinen, M.; Koljonen, T.; Kihlman, S.; Lauri, L.S. Role of critical metals in the future markets of clean energy technologies. Renew. Energy 2016, 95, 53-62. [CrossRef]

16. Gulley, A.L.; Nassar, N.T.; Xun, S. China, the United States, and competition for resources that enable emerging technologies. Proc. Natl. Acad. Sci. USA 2018, 115, 4111-4115. [CrossRef]

17. Nassar, N.T.; Brainard, J.; Gulley, A.; Manley, R.; Matos, G.; Lederer, G.; Bird, L.R.; Pineault, D.; Alonso, E.; Gambogi, J.; et al. Evaluating the mineral commodity supply risk of the U.S. Manufacturing sector. Sci. Adv. 2020, 6, eaay8647. [CrossRef] [PubMed]

18. Yuan, Y.; Yellishetty, M.; Mudd, G.M.; Muñoz, M.A.; Northey, S.A.; Werner, T.T. Toward dynamic evaluations of materials criticality: A systems framework applied to platinum. Resour. Conserv. Recycl. 2020, 152, 104532. [CrossRef]

19. Kiemel, S.; Smolinka, T.; Lehner, F.; Full, J.; Sauer, A.; Miehe, R. Critical materials for water electrolysers at the example of the energy transition in Germany. Int. J. Energy Res. 2021, 45, 9914-9935. [CrossRef]

20. Crundwell, F.; Moats, M.; Ramachandran, V.; Robinson, T.; Davenport, W.G. Extractive Metallurgy of Nickel, Cobalt and Platinum Group Metals; Elsevier: Amsterdam, The Netherlands, 2011.

21. Cramer, L.A. The extractive metallurgy of South Africa's platinum ores. JOM 2001, 53, 14-18. [CrossRef]

22. Vermaak, C.F.; Hendriks, L.P. A review of the mineralogy of the Merensky Reef, with specific reference to new data on the precious metal mineralogy. Econ. Geol. 1976, 71, 1244-1269. [CrossRef]

23. Corrans, I.J.; Dunne, R.C.; Allison, S.A. Recovery of Platinum-Group Metals from the Chromite Reefs of the Bushveld Complex; The Canadian Institute of Mining and Metallurgy: Ottawa, ON, Canada, 1983; pp. II.-10.1-II.-10.21.

24. Kyriakakis, G. Extraction of gold from platinum group metal (PGM) ores. Dev. Miner. Process. 2005, 15, 897-917. [CrossRef]

25. Cowley, A. PGM Market Report; Johnson Matthey: London, UK, 2016.

26. Starostin, V.I.; Sorokhtin, O.G. A new interpretation for the origin of the Norilsk type PGE-Cu-Ni sulfide deposits. Geosci. Front. 2011, 2, 583-591. [CrossRef]

27. Cowley, A.; Ryan, M.; Brisley, B. PGM Market Report; Johnson Matthey: London, UK, 2019.

28. Biggs, T.; Taylor, S.S.; van der Lingen, E. The hardening of platinum alloys for potential jewellery application. Platin. Met. Rev. 2005, 49, 2-15. [CrossRef]

29. Böck, R. Use and demand of palladium for the industry. In Palladium Emissions in the Environment: Analytical Methods, Environmental Assessment and Health Effects; Springer: Berlin, Germany, 2006; pp. 39-51. 
30. Johsnson Matthey Technology Review. Platinum 2004. Platin. Met. Rev. 2004, 48, 133. [CrossRef]

31. Weisberg, A.M. Rhodium plating. Met. Finish. 2002, 100, 278-282. [CrossRef]

32. Morris, D.; McGrath, R. ZGS Platinum Materials for Improved Glass Manufacturing Equipment and Laboratory Ware. Platin. Met. Rev. 2013, 57, 230-232. [CrossRef]

33. Rana, B.B. Corrosion by a heavy metal oxide glass. J. Mater. Sci. Technol. 2005, 21, 243-245. [CrossRef]

34. Dos Santos, I.M.G.; Moreira, R.C.M.; de Souza, A.G.; Paskocimas, C.A.; Leite, E.R.; Varela, J.A.; Longo, E. Ceramic crucible corrosion by heavy metal oxide glasses-Phenomenological study. Int. Ceram. Rev. 2005, 54, 5-8.

35. Matthey, J. Electronic Components. Available online: http://www.platinum.matthey.com/about-pgm/applications/industrial/ electronic-components\# (accessed on 15 January 2021).

36. Trento, C. The Container of Artificial Crystal Growth: Iridium Crucible. Available online: https://www.samaterials.com/ content/the-container-of-artificial-crystal-growth-iridium-crucible.html (accessed on 26 January 2021).

37. Smith, S. The Global Lithium Tantalate Wafers Market Size Is Expected to Reach USD 2.87 Billion by 2024 . Available online: https:/ / www.prnewswire.com/news-releases/the-global-lithium-tantalate-wafers-market-size-is-expected-to-reach-usd2-87-billion-by-2024--300755464.html (accessed on 26 February 2021).

38. Gunn, G. Critical Metals Handbook; John Wiley \& Sons: Hoboken, NJ, USA, 2013; pp. 1-439.

39. Im, T.; Pyo, J.; Lee, J.S.; Lee, C.S. Fabrication of homogeneous nanosized nickel powders using a planetary ball mill: Applications to multilayer ceramic capacitors (MLCCs). Powder Technol. 2021, 382, 118-125. [CrossRef]

40. Jahn, W. Contact materials for reed switches. In Proceedings of the Annual Holm Conference on Electrical Contacts, Montreal, QC, Canada, 20-24 August 1990; pp. 53-58.

41. Weisberg, A.M. Ruthenium plating. Met. Finish. 2002, 100, 283. [CrossRef]

42. He, P.; Hu, G.; Wang, C.; Hewage, K.; Sadiq, R.; Feng, H. Analyzing present and future availability of critical high-tech minerals in waste cellphones: A case study of India. Waste Manag. 2021, 119, 275-284. [CrossRef]

43. Kim, K.S.; Jung, K.H.; Park, B.G.; Shin, Y.E.; Jung, S.B. Characterization of Ag-Pd nanocomposite paste for electrochemical migration resistance. J. Nanosci. Nanotechnol. 2013, 13, 7620-7624. [CrossRef]

44. Le, V.-G.; Vu, C.-T.; Shih, Y.-J.; Huang, Y.-H. Highly efficient recovery of ruthenium from integrated circuit (IC) manufacturing wastewater by $\mathrm{Al}$ reduction and cementation. RSC Adv. 2019, 9, 25303-25308. [CrossRef]

45. Hou, J.; Yang, M.; Ke, C.; Wei, G.; Priest, C.; Qiao, Z.; Wu, G.; Zhang, J. Platinum-group-metal catalysts for proton exchange membrane fuel cells: From catalyst design to electrode structure optimization. EnergyChem 2020, 2, 100023. [CrossRef]

46. Nørskov, J.K.; Rossmeisl, J.; Logadottir, A.; Lindqvist, L.; Kitchin, J.R.; Bligaard, T.; Jónsson, H. Origin of the Overpotential for Oxygen Reduction at a Fuel-Cell Cathode. J. Phys. Chem. B 2004, 108, 17886-17892. [CrossRef]

47. Chung, H.T.; Cullen, D.A.; Higgins, D.; Sneed, B.T.; Holby, E.F.; More, K.L.; Zelenay, P. Direct atomic-level insight into the active sites of a high-performance PGM-free ORR catalyst. Science 2017, 357, 479. [CrossRef] [PubMed]

48. Thompson, S.T.; Papageorgopoulos, D. Platinum group metal-free catalysts boost cost competitiveness of fuel cell vehicles. Nat. Catal. 2019, 2, 558-561. [CrossRef]

49. Kneebone, J.L.; Daifuku, S.L.; Kehl, J.A.; Wu, G.; Chung, H.T.; Hu, M.Y.; Alp, E.E.; More, K.L.; Zelenay, P.; Holby, E.F.; et al. A Combined Probe-Molecule, Mössbauer, Nuclear Resonance Vibrational Spectroscopy, and Density Functional Theory Approach for Evaluation of Potential Iron Active Sites in an Oxygen Reduction Reaction Catalyst. J. Phys. Chem. C 2017, 121, 16283-16290. [CrossRef]

50. Minke, C.; Suermann, M.; Bensmann, B.; Hanke-Rauschenbach, R. Is iridium demand a potential bottleneck in the realization of large-scale PEM water electrolysis? Int. J. Hydrog. Energy 2021, 46, 23581-23590. [CrossRef]

51. Stropnik, R.; Sekavčnik, M.; Ferriz, A.M.; Mori, M. Reducing environmental impacts of the ups system based on PEM fuel cell with circular economy. Energy 2018, 165, 824-835. [CrossRef]

52. Okada, S.; Okinaka, K.; Iwawaki, H.; Furugori, M.; Hashimoto, M.; Mukaide, T.; Kamatani, J.; Igawa, S.; Tsuboyama, A.; Takiguchi, T.; et al. Substituent effects of iridium complexes for highly efficient red OLEDs. Dalton Trans. 2005, 1583-1590. [CrossRef]

53. Pode, R. Organic light emitting diode devices: An energy efficient solid state lighting for applications. Renew. Sustain. Energy Rev. 2020, 133, 110043. [CrossRef]

54. Schmidt, T.; Abbott, J.D. Coronary Stents: History, Design, and Construction. J. Clin. Med. 2018, 7, 126. [CrossRef]

55. Jorge, C.; Dubois, C. Clinical utility of platinum chromium bare-metal stents in coronary heart disease. Med Devices 2015, 8, 359-367. [CrossRef]

56. Walton, C.; Gergely, S.; Economides, A.P. Platinum Pacemaker Electrodes: Origins and Effects of the Electrode-Tissue Interface Impedance. Pacing Clin. Electrophysiol. 1987, 10, 87-99. [CrossRef]

57. DiFilippo, F.P.; Brunken, R.C. Do implanted pacemaker leads and ICD leads cause metal-related artifact in cardiac PET/CT? J. Nucl. Med. 2005, 46, 436-443. [PubMed]

58. Winslow, B.D.; Christensen, M.B.; Yang, W.-K.; Solzbacher, F.; Tresco, P.A. A comparison of the tissue response to chronically implanted Parylene-C-coated and uncoated planar silicon microelectrode arrays in rat cortex. Biomaterials 2010, 31, 9163-9172. [CrossRef]

59. Kang, S.K.; Murphy, R.K.J.; Hwang, S.W.; Lee, S.M.; Harburg, D.V.; Krueger, N.A.; Shin, J.; Gamble, P.; Cheng, H.; Yu, S.; et al. Bioresorbable silicon electronic sensors for the brain. Nature 2016, 530, 71-76. [CrossRef]

60. Knosp, H.; Holliday, R.J.; Corti, C.W. Gold in dentistry: Alloys, uses and performance. Gold Bull. 2003, 36, 93-102. [CrossRef] 
61. Nakaya Fountain Pen, Co. Available online: https://www.nakaya.org/en/manual/default.aspx?item=pensaki (accessed on 16 January 2021).

62. Osmium. Available online: https://www.rsc.org/periodic-table/element/76/osmium\#: \{\}:text=Osmium\%20has $\% 20$ only $\% 20$ a\%20few,chemical\%20industry\%20as\%20a\%20catalyst (accessed on 16 January 2021).

63. McIntosh Reid. Osmiridium in Tasmania; Tasmanian Department of Mines: Hobart, TAS, Australia, $1921 ;$ p. 123.

64. Rudder, D. Specimen of Native Osmiridium. Available online: https://collection.maas.museum/object/218132 (accessed on 16 January 2021).

65. Peters, K.R. Metal deposition by high energy sputtering for high magnification electron microscopy. In Biological Electron Microscopy III; Koehler, J.K., Ed.; Springer: Berlin, Germany, 1986.

66. Tsolaki, E.; Pitta, P.; Diamadopoulos, E. Electrochemical disinfection of simulated ballast water using Artemia salina as indicator. Chem. Eng. J. 2010, 156, 305-312. [CrossRef]

67. Tsolaki, E.; Diamadopoulos, E. Technologies for ballast water treatment: A review. J. Chem. Technol. Biotechnol. 2010, 85, 19-32. [CrossRef]

68. Couderc, C. Platinum Group Metals in Glass Making. Platin. Met. Rev. 2010, 54, 186-191. [CrossRef]

69. Chancerel, P.; Meskers, C.E.M.; Hagelüken, C.; Rotter, V.S. Assessment of precious metal flows during preprocessing of waste electrical and electronic equipment. J. Ind. Ecol. 2009, 13, 791-810. [CrossRef]

70. Ueda, T.; Ichiishi, S.; Okuda, A.; Matsutani, K. Refining and recycling technologies for precious metals. In Metal Sustainability: Global Challenges, Consequences, and Prospects; John Wiley \& Sons: Hoboken, NJ, USA, 2016; pp. 333-360.

71. Johnson Matthey. Available online: http://www.platinum.matthey.com/about-pgm/applications/industrial/hard-disks (accessed on 26 February 2021).

72. Reller, A.; Bublies, T.; Staudinger, T.; Oswald, I.; Meissner, S.; Allen, M. The mobile phone: Powerful communicator and potential metal dissipator. GAIA 2009, 18, 127-135. [CrossRef]

73. Tan, Q.; Dong, Q.; Liu, L.; Song, Q.; Liang, Y.; Li, J. Potential recycling availability and capacity assessment on typical metals in waste mobile phones: A current research study in China. J. Clean. Prod. 2017, 148, 509-517. [CrossRef]

74. Statista. Available online: https://www.statista.com/statistics/330695/number-of-smartphone-users-worldwide/ (accessed on 6 June 2021).

75. Banham, D.; Zou, J.; Mukerjee, S.; Liu, Z.; Yang, D.; Zhang, Y.; Peng, Y.; Dong, A. Ultralow platinum loading proton exchange membrane fuel cells: Performance losses and solutions. J. Power Sources 2021, 490, 229515. [CrossRef]

76. Muhler, M.; Rosowski, F.; Hinrichsen, O.; Hornung, A.; Ertl, G. Ruthenium as catalyst for ammonia synthesis. Stud. Surf. Sci. Catal. 1996, 101 A, 317-326.

77. Siporin, S.E.; Davis, R.J. Use of kinetic models to explore the role of base promoters on $\mathrm{Ru} / \mathrm{MgO}$ ammonia synthesis catalysts. J. Catal. 2004, 225, 359-368. [CrossRef]

78. Cowley, A.; Woodward, B. A healthy future: Platinum in medical applications platinum group metals enhance the quality of life of the global population. Platin. Met. Rev. 2011, 55, 98-107. [CrossRef]

79. Groothuis, J.; Ramsey, N.F.; Ramakers, G.M.J.; van der Plasse, G. Physiological Challenges for Intracortical Electrodes. Brain Stimul. 2014, 7, 1-6. [CrossRef] [PubMed]

80. Prasad, A.; Xue, Q.-S.; Sankar, V.; Nishida, T.; Shaw, G.; Streit, W.J.; Sanchez, J.C. Comprehensive characterization and failure modes of tungsten microwire arrays in chronic neural implants. J. Neural Eng. 2012, 9, 056015. [CrossRef]

81. Kiilunen, M.; Aitio, A.; Santonen, T. Chapter 50-Platinum*. In Handbook on the Toxicology of Metals, 4th ed.; Nordberg, G.F., Fowler, B.A., Nordberg, M., Eds.; Academic Press: San Diego, CA, USA, 2015; pp. 1125-1141.

82. Iavicoli, I.; Leso, V. Chapter 40-Iridium. In Handbook on the Toxicology of Metals, 4th ed.; Nordberg, G.F., Fowler, B.A., Nordberg, M., Eds.; Academic Press: San Diego, CA, USA, 2015; pp. 855-878.

83. Johnson, A.; Shiraishi, T. Biocompatibility of precious metals for medical applications. In Precious Metals for Biomedical Applications; Elsevier: Amsterdam, The Netherlands, 2014; pp. 37-55.

84. Umemura, T.; Sato, K.; Kusaka, Y.; Satoh, H. Chapter 49-Palladium. In Handbook on the Toxicology of Metals, 4th ed.; Nordberg, G.F., Fowler, B.A., Nordberg, M., Eds.; Academic Press: San Diego, CA, USA, 2015; pp. 1113-1123.

85. Dilruba, S.; Kalayda, G.V. Platinum-based drugs: Past, present and future. Cancer Chemother. Pharmacol. 2016, 77, 1103-1124. [CrossRef] [PubMed]

86. Godlewska-Żyłkiewicz, B.; Sawicka, S.; Karpińska, J. Removal of Platinum and Palladium from Wastewater by Means of Biosorption on Fungi Aspergillus sp. and Yeast Saccharomyces sp. Water 2019, 11, 1522. [CrossRef]

87. Tytła, M. Assessment of heavy metal pollution and potential ecological risk in sewage sludge from municipal wastewater treatment plant located in the most industrialized region in poland-Case study. Int. J. Environ. Res. Public Health 2019, 16, 2430. [CrossRef] [PubMed]

88. Goldner, S. Everything You Need to Know about Recycling Your Post-Cremation Metals. Funeral Business Advisor Magazine. 2021. Available online: https:/ / funeralbusinessadvisor.com/everything-you-need-to-know-about-recycling-your-cremationmetals / funeral-business-advisor (accessed on 16 March 2021).

89. Stewart, D. Iridium Element Facts. Available online: https://www.chemicool.com/elements/iridium.html (accessed on 3 January 2021). 
90. Pujadó, P.R.; Rabó, J.A.; Antos, G.J.; Gembicki, S.A. Industrial catalytic applications of molecular sieves. Catal. Today 1992, 13, 113-141. [CrossRef]

91. Wacławek, S.; Padil, V.V.T.; Černík, M. Major Advances and Challenges in Heterogeneous Catalysis for Environmental Applications: A Review. Ecol. Chem. Eng. S 2018, 25, 9-34. [CrossRef]

92. Hagen, J. Industrial Catalysis: A Practical Approach; Wiley: Hoboken, NJ, USA, 2015; pp. 1-522.

93. Jha, M.K.; Lee, J.C.; Kim, M.S.; Jeong, J.; Kim, B.S.; Kumar, V. Hydrometallurgical recovery/recycling of platinum by the leaching of spent catalysts: A review. Hydrometallurgy 2013, 133, 23-32. [CrossRef]

94. Bullock, R.M.; Che, J.G.; Gagliardi, L.; Chiri, P.J.; Farh, O.K.; Hendo, C.H.; Jone, C.W.; Keit, J.A.; Klosin, J.; Mintee, S.D.; et al. Using nature's blueprint to expand catalysis with Earth-abundant metals. Science 2020, 369, eabc3183. [CrossRef]

95. Deraedt, C.; D’Halluin, M.; Astruc, D. Metathesis reactions: Recent trends and challenges. Eur. J. Inorg. Chem. 2013, 4881-4908. [CrossRef]

96. Grubbs, R.H. Olefin metathesis. Tetrahedron 2004, 60, 7117-7140. [CrossRef]

97. Brown, D.E.; Edmonds, T.; Joyner, R.W.; McCarroll, J.J.; Tennison, S.R. The genesis and development of the commercial BP doubly promoted catalyst for ammonia synthesis. Catal. Lett. 2014, 144, 545-552. [CrossRef]

98. Bielawa, H.; Hinrichsen, O.; Birkner, A.; Muhler, M. The ammonia-synthesis catalyst of the next generation: Barium-promoted oxide-supported ruthenium. Angew. Chem. Int. Ed. 2001, 40, 1061-1063. [CrossRef]

99. Giddey, S.; Badwal, S.P.S.; Munnings, C.; Dolan, M. Ammonia as a Renewable Energy Transportation Media. ACS Sustain. Chem. Eng. 2017, 5, 10231-10239. [CrossRef]

100. Saadatjou, N.; Jafari, A.; Sahebdelfar, S. Ruthenium Nanocatalysts for Ammonia Synthesis: A Review. Chem. Eng. Commun. 2015, 202, 420-448. [CrossRef]

101. Ohkuma, T.; Ooka, H.; Ikariya, T.; Noyori, R. Preferential hydrogenation of aldehydes and ketones. J. Am. Chem. Soc. 1995, 117, 10417-10418. [CrossRef]

102. Giarola, S.; Romain, C.; Williams, C.K.; Hallett, J.P.; Shah, N. Techno-economic assessment of the production of phthalic anhydride from corn stover. Chem. Eng. Res. Des. 2016, 107, 181-194. [CrossRef]

103. Monflier, E.; Bourdauducq, P.; Couturier, J.-L.; Kervennal, J.; Mortreux, A. Palladium catalyzed telomerization of butadiene with water in a two phase system: Drastic effect of the amine structure on the rate and selectivity. J. Mol. Catal. A Chem. 1995, 97, 29-33. [CrossRef]

104. Lee, B.I.; Lee, K.H.; Lee, J.S. Telomerization of butadiene with water catalyzed by heterogeneous palladium catalysts. J. Mol. Catal. A Chem. 2000, 156, 283-287. [CrossRef]

105. Guisnet, M.; Gnep, N.S.; Morin, S. Mechanisms of xylene isomerization over acidic solid catalysts. Microporous Mesoporous Mater. 2000, 35-36, 47-59. [CrossRef]

106. Theis, J.R.; Ura, J.A.; Li, J.J.; Surnilla, G.G.; Roth, J.M.; Goralski, C.T., Jr. NOx release characteristics of lean NOx traps during rich purges. In Proceedings of the SAE 2003 World Congress \& Exhibition, Detroit, MI, USA, 3-7 March 2003; pp. 758-775. [CrossRef]

107. Gelles, T.; Krishnamurthy, A.; Adebayo, B.; Rownaghi, A.; Rezaei, F. Abatement of gaseous volatile organic compounds: A material perspective. Catal. Today 2020, 350, 3-18. [CrossRef]

108. He, C.; Cheng, J.; Zhang, X.; Douthwaite, M.; Pattisson, S.; Hao, Z. Recent Advances in the Catalytic Oxidation of Volatile Organic Compounds: A Review Based on Pollutant Sorts and Sources. Chem. Rev. 2019, 119, 4471-4568. [CrossRef] [PubMed]

109. Krishnamurthy, A.; Adebayo, B.; Gelles, T.; Rownaghi, A.; Rezaei, F. Abatement of gaseous volatile organic compounds: A process perspective. Catal. Today 2020, 350, 100-119. [CrossRef]

110. Janssen, F.J. Environmental Catalysis-Stationary Sources. In Environmental Catalysis; Wiley: Hoboken, NJ, USA, 2008; pp. 119-179.

111. Asakura, H.; Kirihara, M.; Fujita, K.; Hosokawa, S.; Kikkawa, S.; Teramura, K.; Tanaka, T. Fe-Modified CuNi Alloy Catalyst as a Nonprecious Metal Catalyst for Three-Way Catalysis. Ind. Eng. Chem. Res. 2020, 59, 19907-19917. [CrossRef]

112. Hirakawa, T.; Shimokawa, Y.; Tokuzumi, W.; Sato, T.; Tsushida, M.; Yoshida, H.; Ohyama, J.; Machida, M. Multicomponent 3d Transition-Metal Nanoparticles as Catalysts Free of Pd, Pt, or Rh for Automotive Three-Way Catalytic Converters. ACS Appl. Nano Mater. 2020, 3, 9097-9107. [CrossRef]

113. Hart, H.; Schuetz, R.D. Organic Chemistry, 4th ed.; Houghton Mifflin Company: Boston, MA, USA, 1972.

114. Ichihashi, H.; Sato, H. The development of new heterogeneous catalytic processes for the production of $\varepsilon$-caprolactam. Appl. Catal. A Gen. 2001, 221, 359-366. [CrossRef]

115. Chen, Z.; Sun, H.; Peng, Z.; Gao, J.; Li, B.; Liu, Z.; Liu, S. Selective Hydrogenation of Benzene: Progress of Understanding for the Ru-Based Catalytic System Design. Ind. Eng. Chem. Res. 2019, 58, 13794-13803. [CrossRef]

116. Neri, G.; Musolino, M.G.; Milone, C.; Pietropaolo, D.; Galvagno, S. Particle size effect in the catalytic hydrogenation of 2,4dinitrotoluene over Pd/C catalysts. Appl. Catal. A Gen. 2001, 208, 307-316. [CrossRef]

117. Look Chem, Production of Toluene Diisocyanate (TDI). Available online: https://www.lookchem.com/Chempedia/ChemicalTechnology /Organic-Chemical-Technology /7800.html (accessed on 1 March 2021).

118. Lakshmi Kantam, M.; Kishore, R.; Yadav, J.; Bhargava, S.K.; Jones, L.A.; Venugopal, A. Chapter 10—Hydrogenation for Fine Chemical Synthesis: Status and Future Perspectives A2-Joshi, Sunil S. In Industrial Catalytic Processes for Fine and Specialty Chemicals; Ranade, V.V., Ed.; Elsevier: Amsterdam, The Netherlands, 2016; pp. 427-462. 
119. Chen, C.; Li, B.; Kanari, M.D.L. Epoxy Adhesives. In Adhesives and Adhesive Joints in Industry; Rudamsk, A., Ed.; Intech Open: London, UK, 2019.

120. Woodbury, R.P.; Thunberg, J.C.; Van Kouwenber, S.P.; Begonis, W.B. Process for the Preparation of 3-cyano-3,5,5Trimethylcyclohexanone. European Patent EP0558332, 26 February 1993.

121. Hofer, R. In Kaisten, syngenta operates the world's largest plant in which an enantioselective catalytic hydrogenation is performed. How did this come about? Chimia 2005, 59, 10-12. [CrossRef]

122. Bhatkhande, D.S.; Pangarkar, V.G.; Beenackers, A.A.C.M. Photocatalytic degradation of nitrobenzene using titanium dioxide and concentrated solar radiation: Chemical effects and scaleup. Water Res. 2003, 37, 1223-1230. [CrossRef]

123. Antos, G.J.; Abdullah, M.A. Catalytic Naphtha Reforming, Revised and Expanded, 2nd ed.; CRC Press: Boca Raton, FL, USA, 2004.

124. National Research Council. Platinum Group Metals 1997; The National Academies Press: Washington, DC, USA, 1997.

125. Hughes, A.E.; Pratt, K.C.; Tsai, P. Examination of de-coking of promoted $(\mathrm{Co}, \mathrm{Ni}) \mathrm{Mo} / \gamma$-Al2O3 catalysts by X-ray photoelectron spectroscopy. Top. Catal. 1992, 90, 117-129. [CrossRef]

126. Yang, C.-J. An impending platinum crisis and its implications for the future of the automobile. Energy Policy 2009, 37, 1805-1808. [CrossRef]

127. Data, O.W.i. Cars, Planes, Trains: Where do $\mathrm{CO}_{2}$ Emissions from Transport Come from? Available online: https:/ / ourworldindata. org/co2-emissions-from-transport (accessed on 1 March 2021).

128. IEA. Global EV Outlook 2020. Available online: https://www.iea.org/reports/global-ev-outlook-2020 (accessed on 19 January 2021).

129. Miller, E.L.; Thompson, S.T.; Randolph, K.; Hulvey, Z.; Rustagi, N.; Satyapal, S. US Department of Energy hydrogen and fuel cell technologies perspectives. MRS Bull. 2020, 45, 57-64. [CrossRef]

130. International Partnership for Hydrogen and Fuel Cells in the Economy. Available online: https://www.iphe.net/ (accessed on 1 March 2021).

131. Ju, H.; Badwal, S.; Giddey, S. A comprehensive review of carbon and hydrocarbon assisted water electrolysis for hydrogen production. Appl. Energy 2018, 231, 502-533. [CrossRef]

132. Liu, M.; Zhao, Z.; Duan, X.; Huang, Y. Nanoscale Structure Design for High-Performance Pt-Based ORR Catalysts. Adv. Mater. 2019, 31, 1802234. [CrossRef] [PubMed]

133. Evans, S. Platinum Potential: How Batteries Could Open the Door to a Mining Rush. Available online: https://www. mining-technology.com/features/platinum-potential-how-batteries-could-open-the-door-to-a-mining-rush/ (accessed on 17 August 2021).

134. Arnold, M.; Pohjalainen, E.; Steger, S.; Kaerger, W.; Welink, J.-H. Economic Viability of Extracting High Value Metals from End of Life Vehicles. Sustainability 2021, 13, 1902. [CrossRef]

135. Ortego, A.; Valero, A.; Valero, A.; Iglesias, M. Downcycling in automobile recycling process: A thermodynamic assessment. Resour. Conserv. Recycl. 2018, 136, 24-32. [CrossRef]

136. Iglesias-Émbil, M.; Valero, A.; Ortego, A.; Villacampa, M.; Vilaró, J.; Villalba, G. Raw material use in a battery electric car-A thermodynamic rarity assessment. Resour. Conserv. Recycl. 2020, 158, 104820. [CrossRef]

137. Choi, J.S.; Kočí, P. Automotive Emission Control Catalysts. Catalysts 2016, 6, 155. [CrossRef]

138. Böck, R. Automotive catalysts. In Palladium Emissions in the Environment: Analytical Methods, Environmental Assessment and Health Effects; Zereini, F., Alt, F., Eds.; Springer: Berlin/Heidelberg, Germany, 2006; pp. 3-23.

139. Matthey, J. The Components of Autocatalyst Demand. Platinum 2013, Special Feature 31-34. Available online: http:// www.platinum.matthey.com/documents / market-review/2013/special-feature-download/the-components-of-autocatalystdemand-.pdf (accessed on 21 February 2021).

140. Zhang, K.; Hu, J.; Gao, S.; Liu, Y.; Huang, X.; Bao, X. Sulfur content of gasoline and diesel fuels in northern China. Energy Policy 2010, 38, 2934-2940. [CrossRef]

141. Zheng, Q.; Farrauto, R.; Deeba, M.; Valsamakis, I. Part I: A Comparative Thermal Aging Study on the Regenerability of Rh/Al2O3 and $\mathrm{Rh} / \mathrm{CexOy}-\mathrm{ZrO}_{2}$ as Model Catalysts for Automotive Three Way Catalysts. Catalysts 2015, 5, 1770. [CrossRef]

142. Johnson, T. Vehicular Emissions in Review. SAE Int. J. Engines 2016, 9, 1258-1275. [CrossRef]

143. West, B.; Huff, S.; Parks, J.; Lewis, S.; Choi, J.S.; Partridge, W.; Storey, J. Assessing reductant chemistry during in-cylinder regeneration of diesel lean NOx traps. SAE Trans. 2004, 1975-1985. [CrossRef]

144. Higgins, A.; Paevere, P.; Gardner, J.; Quezada, G. Combining choice modelling and multi-criteria analysis for technology diffusion: An application to the uptake of electric vehicles. Technol. Forecast. Soc. Change 2012, 79, 1399-1412. [CrossRef]

145. Ikemezu, Y. How Palladium and Platinum's Success Is Linked to Electric Vehicles. Available online: https:/ / www.theassay.com/ articles/how-palladium-and-platinums-success-is-linked-to-electric-vehicles / (accessed on 21 February 2021).

146. International Energy Agency. Global EV Outlook 2018; International Energy Agency: Paris, France, 2018.

147. Brandon, N.P.; Parkes, M.A. Fuel cells: Materials. In Reference Module in Materials Science and Materials Engineering; Elsevier: Amsterdam, The Netherlands, 2016.

148. Types of Fuel Cells. Available online: https://www.energy.gov/eere/fuelcells/types-fuel-cells (accessed on 17 January 2021).

149. Application 28-Development of fuel cells. In Nanoparticle Technology Handbook; Hosokawa, M.; Nogi, K.; Naito, M.; Yokoyama, T. (Eds.) Elsevier: Amsterdam, The Netherlands, 2008; pp. 538-543. 
150. Pollet, B.G.; Kocha, S.S.; Staffell, I. Current status of automotive fuel cells for sustainable transport. Curr. Opin. Electrochem. 2019, 16, 90-95. [CrossRef]

151. Eapen, D.E.; Suseendiran, S.R.; Rengaswamy, R. 2-Phosphoric acid fuel cells. In Compendium of Hydrogen Energy; Barbir, F., Basile, A., Veziroğlu, T.N., Eds.; Woodhead Publishing: Oxford, UK, 2016; pp. 57-70.

152. Kordesch, K.; Hacker, V.; Gsellmann, J.; Cifrain, M.; Faleschini, G.; Enzinger, P.; Fankhauser, R.; Ortner, M.; Muhr, M.; Aronson, R.R. Alkaline fuel cells applications. J. Power Sources 2000, 86, 162-165. [CrossRef]

153. Kruusenberg, I.; Matisen, L.; Shah, Q.; Kannan, A.M.; Tammeveski, K. Non-platinum cathode catalysts for alkaline membrane fuel cells. Int. J. Hydrog. Energy 2012, 37, 4406-4412. [CrossRef]

154. Kamarudin, S.K.; Achmad, F.; Daud, W.R.W. Overview on the application of direct methanol fuel cell (DMFC) for portable electronic devices. Int. J. Hydrog. Energy 2009, 34, 6902-6916. [CrossRef]

155. Munjewar, S.S.; Thombre, S.B.; Mallick, R.K. Approaches to overcome the barrier issues of passive direct methanol fuel cellReview. Renew. Sustain. Energy Rev. 2017, 67, 1087-1104. [CrossRef]

156. Klingenhof, M.; Hauke, P.; Brückner, S.; Dresp, S.; Wolf, E.; Nong, H.N.; Spöri, C.; Merzdorf, T.; Bernsmeier, D.; Teschner, D.; et al. Modular Design of Highly Active Unitized Reversible Fuel Cell Electrocatalysts. ACS Energy Lett. 2021, 6, 177-183. [CrossRef]

157. Wagner, F.T.; Lakshmanan, B.; Mathias, M.F. Electrochemistry and the future of the automobile. J. Phys. Chem. Lett. 2010, 1, 2204-2219. [CrossRef]

158. Tian, X.; Lu, X.F.; Xia, B.Y.; Lou, X.W.D. Advanced Electrocatalysts for the Oxygen Reduction Reaction in Energy Conversion Technologies. Joule 2020, 4, 45-68. [CrossRef]

159. Ganesan, A.; Narayanasamy, M. Ultra-low loading of platinum in proton exchange membrane-based fuel cells: A brief review. Mater. Renew. Sustain. Energy 2019, 8, 18. [CrossRef]

160. Miller, E.L.; Randolph, K.; Peterson, D.; Rustagi, N.; Cierpik-Gold, K.; Klahr, B.; Gomez, J.C. Innovative approaches to addressing the fundamental materials challenges in hydrogen and fuel cell technologies. MRS Advances 2016, 1, 3107-3119. [CrossRef]

161. Hao, H.; Geng, Y.; Tate, J.E.; Liu, F.; Sun, X.; Mu, Z.; Xun, D.; Liu, Z.; Zhao, F. Securing Platinum-Group Metals for Transport Low-Carbon Transition. One Earth 2019, 1, 117-125. [CrossRef]

162. Wittstock, R.; Pehlken, A.; Wark, M. Challenges in automotive fuel cells recycling. Recycling 2016, 1, 343. [CrossRef]

163. Fairchild, M.R.; Taylor, R.; Berlin, C.; Wong, C.; Ma, B.; Balachandran, U. Thin-film high voltage capacitors on ultra-thin glass for electric drive vehicle inverter applications. SAE Tech. Pap. 2014, 1. [CrossRef]

164. Slater, D. Platinum Group Metals Take Another Step Closer to Use in Battery Electric Vehicles. Available online: https: / / www.miningweekly.com/article/platinum-group-metals-take-another-step-closer-to-use-in-battery-electric-vehicles-2021 -01-19/rep_id:3650 (accessed on 21 February 2021).

165. Kurien, C.; Srivastava, A.K.; Molere, E. Emission control strategies for automotive engines with scope for deployment of solar based e-vehicle charging infrastructure. Environ. Prog. Sustain. Energy 2020, 39, 13267. [CrossRef]

166. Saurat, M.; Bringezu, S. Platinum group metal flows of europe, part II exploring the technological and institutional potential for reducing environmental impacts. J. Ind. Ecol. 2009, 13, 406-421. [CrossRef]

167. Evangelisti, S.; Tagliaferri, C.; Brett, D.J.L.; Lettieri, P. Life cycle assessment of a polymer electrolyte membrane fuel cell system for passenger vehicles. J. Clean. Prod. 2017, 142, 4339-4355. [CrossRef]

168. Bernhart, W.; Riederle, S.; Yoon, M.; Aulbur, W.G. Fuel Cells-A Realistic Alternative for Zero Emission? Auto Tech Rev. 2014, 3 , 20-23. [CrossRef]

169. Bermudez, J.M.H.T. Hydrogen; IEA: Paris, France, 2020.

170. Wind, J. 1-Hydrogen-fueled road automobiles-Passenger cars and buses. In Compendium of Hydrogen Energy; Ball, M., Basile, A., Veziroğlu, T.N., Eds.; Woodhead Publishing: Oxford, UK, 2016; pp. 3-21.

171. Notter, D.A.; Kouravelou, K.; Karachalios, T.; Daletou, M.K.; Haberland, N.T. Life cycle assessment of PEM FC applications: Electric mobility and $\mu$-CHP. Energy Environ. Sci. 2015, 8, 1969-1985. [CrossRef]

172. Simons, A.; Bauer, C. A life-cycle perspective on automotive fuel cells. Appl. Energy 2015, 157, 884-896. [CrossRef]

173. Banham, D.; Ye, S. Current status and future development of catalyst materials and catalyst layers for proton exchange membrane fuel cells: An industrial perspective. ACS Energy Lett. 2017, 2, 629-638. [CrossRef]

174. Cano, Z.P.; Banham, D.; Ye, S.; Hintennach, A.; Lu, J.; Fowler, M.; Chen, Z. Batteries and fuel cells for emerging electric vehicle markets. Nat. Energy 2018, 3, 279-289. [CrossRef]

175. Ren, X.; Lv, Q.; Liu, L.; Liu, B.; Wang, Y.; Liu, A.; Wu, G. Current progress of Pt and Pt-based electrocatalysts used for fuel cells. Sustain. Energy Fuels 2020, 4, 15-30. [CrossRef]

176. Kongkanand, A.; Mathias, M.F. The Priority and Challenge of High-Power Performance of Low-Platinum Proton-Exchange Membrane Fuel Cells. J. Phys. Chem. Lett. 2016, 7, 1127-1137. [CrossRef]

177. Mortensen, J.J.; Ganduglia-Pirovano, M.V.; Hansen, L.B.; Hammer, B.; Stoltze, P.; Nørskov, J.K. Nitrogen adsorption on Fe(111), (100), and (110) surfaces. Surf. Sci. 1999, 422, 8-16. [CrossRef]

178. Logadottir, A.; Rod, T.H.; Nørskov, J.K.; Hammer, B.; Dahl, S.; Jacobsen, C.J.H. The Brønsted-Evans-Polanyi relation and the volcano plot for ammonia synthesis over transition metal catalysts. J. Catal. 2001, 197, 229-231. [CrossRef]

179. Dahl, S.; Logadottir, A.; Jacobsen, C.J.H.; Norskov, J.K. Electronic factors in catalysis: The volcano curve and the effect of promotion in catalytic ammonia synthesis. Appl. Catal. A Gen. 2001, 222, 19-29. [CrossRef] 
180. Strongin, D.R.; Carrazza, J.; Bare, S.R.; Somorjai, G.A. The importance of C7 sites and surface roughness in the ammonia synthesis reaction over iron. J. Catal. 1987, 103, 213-215. [CrossRef]

181. Homann, K.; Kuhlenbeck, H.; Freund, H.J. N2 adsorption and dissociation on thin iron films on W(110). Surf. Sci. 1995, 327, 216-224. [CrossRef]

182. Mortensen, J.J.; Hansen, L.B.; Hammer, B.; Nørskov, J.K. Nitrogen adsorption and dissociation on Fe(111). J. Catal. 1999, 182, 479-488. [CrossRef]

183. Dumesic, J.A.; Topsøe, H.; Boudart, M. Surface, catalytic and magnetic properties of small iron particles. III. Nitrogen induced surface reconstruction. J. Catal. 1975, 37, 513-522. [CrossRef]

184. Imbihl, R.; Behm, R.J.; Ertl, G.; Moritz, W. The structure of atomic nitrogen adsorbed on Fe(100). Surf. Sci. 1982, 123, 129-140. [CrossRef]

185. Strongin, D.R.; Bare, S.R.; Somorjai, G.A. The effects of aluminum oxide in restructuring iron single crystal surfaces for ammonia synthesis. J. Catal. 1987, 103, 289-301. [CrossRef]

186. Jacobsen, C.J.H.; Dahl, S.; Clausen, B.G.S.; Bahn, S.; Logadottir, A.; Nørskov, J.K. Catalyst design by interpolation in the periodic table: Bimetallic ammonia synthesis catalysts. J. Am. Chem. Soc. 2001, 123, 8404-8405. [CrossRef]

187. Ertl, G. Primary steps in catalytic synthesis of ammonia. J. Vac. Sci. Technol. A Vac. Surf. Film. 1983, 1, 1247-1253. [CrossRef]

188. Lubkowski, K.; Grzmil, B.; Arabczyk, W. Activation of the prereduced ammonia iron catalyst. Catal. Commun. 2008, 9, 2099-2102. [CrossRef]

189. Bosch, H.; van Ommen, J.G.; Gellings, P.J. On the role of alkali metals in ammonia synthesis. Appl. Catal. 1985, 18, 405-408. [CrossRef]

190. Song, Z.; Cai, T.; Hanson, J.C.; Rodriguez, J.A.; Hrbek, J. Structure and reactivity of Ru nanoparticles supported on modified graphite surfaces: A study of the model catalysts for ammonia synthesis. J. Am. Chem. Soc. 2004, 126, 8576-8584. [CrossRef]

191. You, Z.; Inazu, K.; Aika, K.i.; Baba, T. Electronic and structural promotion of barium hexaaluminate as a ruthenium catalyst support for ammonia synthesis. J. Catal. 2007, 251, 321-331. [CrossRef]

192. Kowalczyk, Z.; Krukowski, M.; Raróg-Pilecka, W.; Szmigiel, D.; Zielinski, J. Carbon-based ruthenium catalyst for ammonia synthesis: Role of the barium and caesium promoters and carbon support. Appl. Catal. A Gen. 2003, 248, 67-73. [CrossRef]

193. Aika, K.I.; Niwa, Y. Basic concepts and properties of new generation ammonia synthesis catalysts for industrial use. Stud. Surf. Sci. Catal. 1999, 121, 327-332. [CrossRef]

194. Kurzman, J.A.; Misch, L.M.; Seshadri, R. Chemistry of precious metal oxides relevant to heterogeneous catalysis. Dalton Trans. 2013, 42, 14653-14667. [CrossRef]

195. Yandulov, D.V.; Schrock, R.R.; Rheingold, A.L.; Ceccarelli, C.; Davis, W.M. Synthesis and reactions of molybdenum triamidoamine complexes containing hexaisopropylterphenyl substituents. Inorg. Chem. 2003, 42, 796-813. [CrossRef] [PubMed]

196. Hellman, A.; Baerends, E.J.; Biczysko, M.; Bligaard, T.; Christensen, C.H.; Clary, D.C.; Dahl, S.; van Harrevelt, R.; Honkala, K.; Jonsson, H.; et al. Predicting catalysis: Understanding ammonia synthesis from first-principles calculations. J. Phys. Chem. B 2006, 110, 17719-17735. [CrossRef] [PubMed]

197. Bibra, E.M.; Connelly, E.; Gorner, M.; Lowans, C.; Paoli, L.; Tattini, J.; Texter, J. Global EV Outlook 2021; International Energy Association: Paris, France, 2021; p. 97.

198. Gröger, O.; Gasteiger, H.A.; Suchsland, J.-P. Review-Electromobility: Batteries or Fuel Cells? J. Electrochem. Soc. 2015, 162, A2605-A2622. [CrossRef]

199. Saurat, M.; Bringezu, S. Platinum group metal flows of Europe, part I: Global supply, use in industry, and shifting of environmental impacts. J. Ind. Ecol. 2008, 12, 754-767. [CrossRef]

200. D'Adamo, I.; Ferella, F.; Gastaldi, M.; Maggiore, F.; Rosa, P.; Terzi, S. Towards sustainable recycling processes: Wasted printed circuit boards as a source of economic opportunities. Resour. Conserv. Recycl. 2019, 149, 455-467. [CrossRef]

201. Hagelüken, C. Recycling the platinum group metals: A European perspective. Platin. Met. Rev. 2012, 56, 29-35. [CrossRef]

202. Bahaloo-Horeh, N.; Mousavi, S.M. Comprehensive characterization and environmental risk assessment of end-of-life automotive catalytic converters to arrange a sustainable roadmap for future recycling practices. J. Hazard. Mater. 2020, 400, 123186. [CrossRef]

203. Hagelüken, C. Closing the loop-Recycling of automotive catalysts. Metall 2007, 61, 24-39.

204. Stropnik, R.; Lotrič, A.; Bernad Montenegro, A.; Sekavčnik, M.; Mori, M. Critical materials in PEMFC systems and a LCA analysis for the potential reduction of environmental impacts with EoL strategies. Energy Sci. Eng. 2019, 7, 2519-2539. [CrossRef]

205. Smith, M.N. The Number of Cars Is Set to Double by 2040. Available online: http://webforum.org/agenda/2016/04/thenumber-of-cars-worlwide-is-set-to-double-by-2040 (accessed on 19 September 2021).

206. Trinh, H.B.; Lee, J.C.; Suh, Y.J.; Lee, J. A review on the recycling processes of spent auto-catalysts: Towards the development of sustainable metallurgy. Waste Manag. 2020, 114, 148-165. [CrossRef] [PubMed]

207. Parkes, G.D.; Mellor, J.W. Mellor's Modern Inorganic Chemistry, 2nd ed.; Longmans Green and Co.: London, UK, 1946 ; p. 915.

208. Morcali, M.H. A new approach to recover platinum-group metals from spent catalytic converters via iron matte. Resour. Conserv. Recycl. 2020, 159. [CrossRef]

209. Duclos, L.; Lupsea, M.; Mandil, G.; Svecova, L.; Thivel, P.-X.; Laforest, V. Environmental assessment of proton exchange membrane fuel cell platinum catalyst recycling. J. Clean. Prod. 2017, 142, 2618-2628. [CrossRef]

210. Carmo, M.; Keeley, G.P.; Holtz, D.; Grube, T.; Robinius, M.; Müller, M.; Stolten, D. PEM water electrolysis: Innovative approaches towards catalyst separation, recovery and recycling. Int. J. Hydrog. Energy 2019, 44, 3450-3455. [CrossRef] 
211. Duclos, L.; Svecova, L.; Laforest, V.; Mandil, G.; Thivel, P.X. Process development and optimization for platinum recovery from PEM fuel cell catalyst. Hydrometallurgy 2016, 160, 79-89. [CrossRef]

212. Pawlak, J.; Lodyga-Chruścińska, E.; Chrustowicz, J. Fate of platinum metals in the environment. J. Trace Elem. Med. Biol. 2014, 28, 247-254. [CrossRef]

213. Wiseman, C.L.S.; Zereini, F. Airborne particulate matter, platinum group elements and human health: A review of recent evidence. Sci. Total Environ. 2009, 407, 2493-2500. [CrossRef] [PubMed]

214. Das, S.; Chellam, S. Estimating light-duty vehicles' contributions to ambient PM2.5 and PM10 at a near-highway urban elementary school via elemental characterization emphasizing rhodium, palladium, and platinum. Sci. Total Environ. 2020, 747, 141268. [CrossRef] [PubMed]

215. Zereini, F.; Wiseman, C.; Püttmann, W. Changes in palladium, platinum, and rhodium concentrations, and their spatial distribution in soils along a major highway in Germany from 1994 to 2004. Environ. Sci. Technol. 2007, 41, 451-456. [CrossRef] [PubMed]

216. Alsohaimi, I.H.; El-Hashemy, M.A.; Al-Ruwaili, A.G.; Seaf El-Nasr, T.A.; Almuaikel, N.S. Assessment of Trace Elements in Urban Road Dust of a City in a Border Province Concerning Their Levels, Sources, and Related Health Risks. Arch. Environ. Contam. Toxicol. 2020, 79, 23-38. [CrossRef] [PubMed]

217. Ek, K.H.; Morrison, G.M.; Rauch, S. Environmental routes for platinum group elements to biological materials-A review. Sci. Total Environ. 2004, 334-335, 21-38. [CrossRef] [PubMed]

218. Dubiella-Jackowska, A.; Kudłak, B.; Polkowska, Z.; Namieśnik, J. Environmental fate of traffic-derived platinum group metals. Crit. Rev. Anal. Chem. 2009, 39, 251-271. [CrossRef]

219. Artelt, S.; Creutzenberg, O.; Kock, H.; Levsen, K.; Nachtigall, D.; Heinrich, U.; Rühle, T.; Schlögl, R. Bioavailability of fine dispersed platinum as emitted from automotive catalytic converters: A model study. Sci. Total Environ. 1999, 228, $219-242$. [CrossRef]

220. Beasley, D.E.; Koltz, A.M.; Lambert, J.E.; Fierer, N.; Dunn, R.R. The evolution of stomach acidity and its relevance to the human microbiome. PLoS ONE 2015, 10, e0134116. [CrossRef]

221. Matodzi, V.; Legodi, M.A.; Tavengwa, N.T. Determination of platinum group metals in dust, water, soil and sediments in the vicinity of a cement manufacturing plant. SN Appl. Sci. 2020, 2, 1090. [CrossRef] 